Nevada

Environmental

Restoration

Project

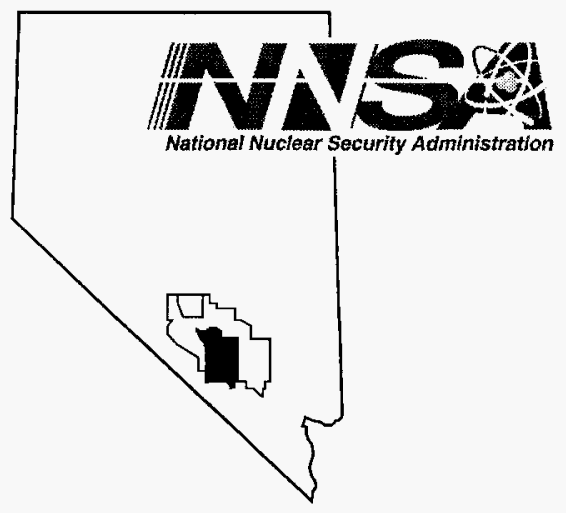

Post-Closure Inspection Report for Corrective Action Unit 92:

Area 6 Decon Pond Facility,

Nevada Test Site, Nevada

For the Period January 2004 -

December 2004

Controlled Copy No.:

Revision: 0

March 2005

Environmental Restoration

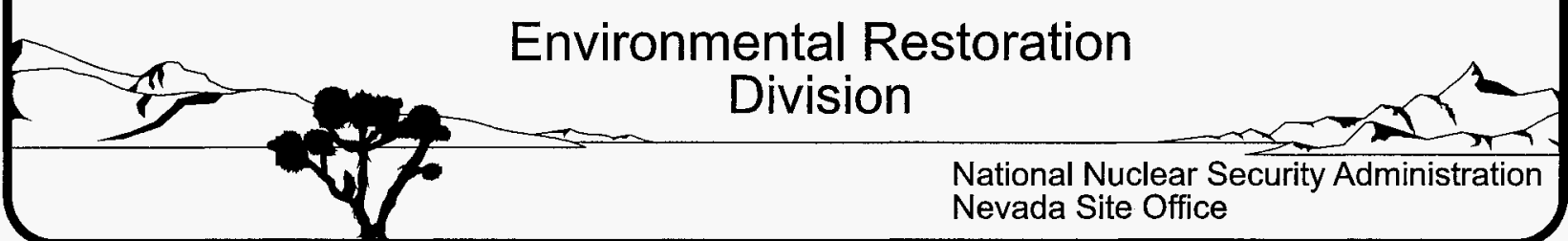




\section{DISCLAIMER}

Reference herein to any specific commercial product, process, or service by trade name, trademark, manufacturer, or otherwise, does not necessarily constitute or imply its endorsement, recommendation, or favoring by the U.S. Government or any agency thereof or its contractors or subcontractors.

This report has been reproduced directly from the best available copy.

Available for sale to the public from:

U.S. Department of Commerce

National Technical Information Service

5285 Port Royal Road

Springfield, VA 22161-0002

Telephone: (800) 553-6847

Fax: (703) 605-6900

E-mail: orders@ntis.gov

Online ordering: http://www.ntis.gov/ordering.htm

Available electronically at http://www.osti.gov/bridge.

Available for a processing fee to the U.S. Department of Energy and its contractors, in paper, from:

U.S. Department of Energy

Office of Scientific and Technical Information

P.O. Box 62

Oak Ridge, TN 37831-0062

Telephone: (865) 576-8401

Fax: (865) 576-5728

E-mail: reports@adonis.osti.gov 


\title{
POST-CLOSURE INSPECTION REPORT FOR CORRECTIVE ACTION UNIT 92: AREA 6 DECON POND FACILITY, NEVADA TEST SITE, NEVADA
}

\section{FOR THE PERIOD \\ JANUARY 2004 - DECEMBER 2004}

\author{
Prepared for: \\ U.S. Department of Energy \\ National Nuclear Security Administration \\ Nevada Site Office \\ Under Contract No. DE-AC08-96NV11718
}

Controlled Copy No.

Revision: 0

March 2005 
THIS PAGE INTENTIONALLY LEFT BLANK 


\title{
POST-CLOSURE INSPECTION REPORT FOR CORRECTIVE ACTION UNIT 92: AREA 6 DECON POND FACILITY, NEVADA TEST SITE, NEVADA
}

\author{
FOR THE PERIOD \\ JANUARY 2004 - DECEMBER 2004
}

\footnotetext{
Approved By: Kenex Calchle Date: $3-1-05$

Sabine T. Curtis, Acting Project Manager Industrial Sites Project Approved By: $\frac{\text { Caderi Arts }}{\text { for Janet L. Appenzeller-Wing, Acting Director }}$

Date: $3-1-05$
} 
THIS PAGE INTENTIONALLY LEFT BLANK 


\section{TABLE OF CONTENTS}

ACRONYMS AND ABBREVIATIONS ............................................................................. vii

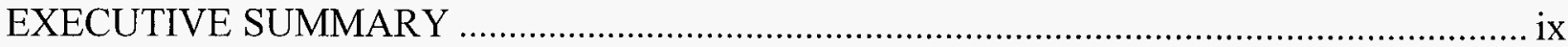

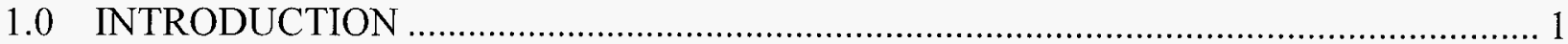

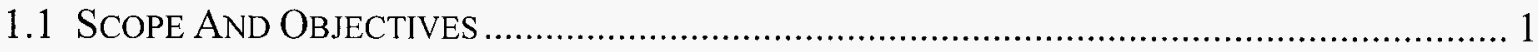

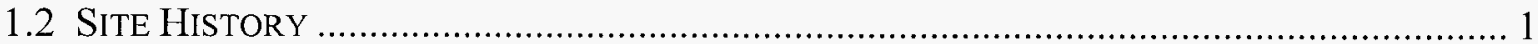

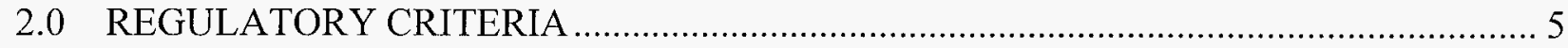

3.0 SITE INSPECTION AND SUBSIDENCE SURVEY RESULTS ….................................. 7

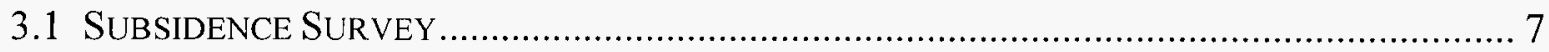

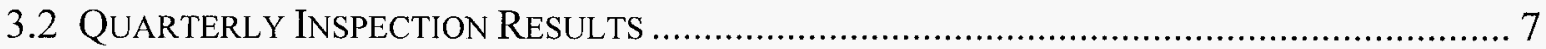

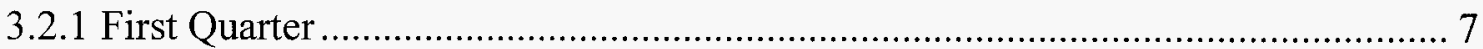

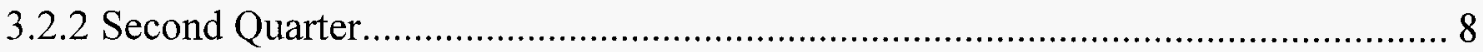

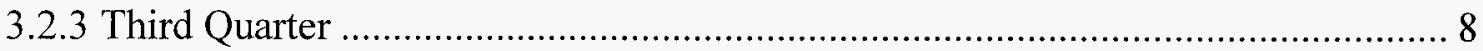

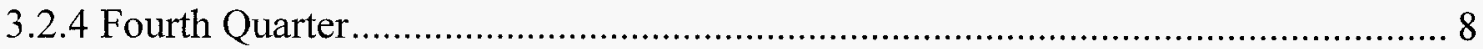

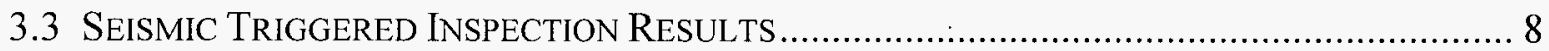

3.4 PRECIPITATION TRIGGERED INSPECTION RESULTS...................................................... 8

4.0 SUMMARY, CONCLUSIONS, AND RECOMMENDATIONS ………......................... 11

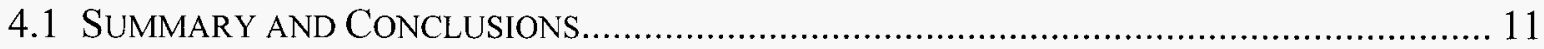

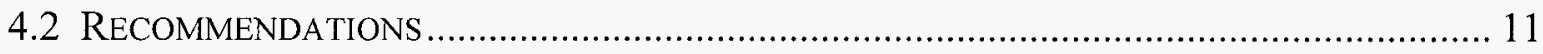

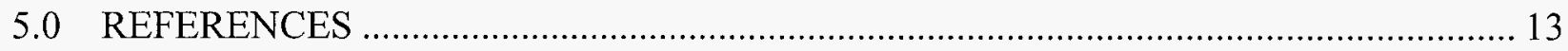

\section{FIGURES}

Figure 1: Location of CAU 92, AREa 6 DeCon Pond FaCILITY ............................................... 2

\section{TABLES}

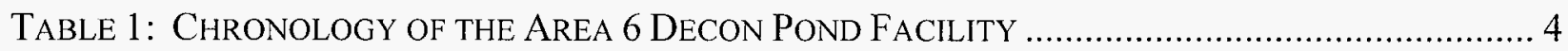

TABLE 2: SubSidenCE Monument SuRvey EleVATIONS ................................................................. 7

\section{APPENDICES}

APPENDIX A: INSPECTION CHECKLISTS AND FIELD NoTES

APPENDIX B: PHOTOGRAPHS

APPENDIX C: PRECIPITATION RECORDS

LIBRARY DISTRIBUTION LIST 
Post-Closure Report - CAU 92

Revision: 0

Date: March 2005

THIS PAGE INTENTIONALLY LEFT BLANK 


\section{ACRONYMS AND ABBREVIATIONS}

$\begin{array}{ll}\text { CAS } & \text { Corrective Action Site } \\ \text { CAU } & \text { Corrective Action Unit } \\ \text { CFR } & \text { Code of Federal Regulations } \\ \mathrm{cm} & \text { centimeter(s) } \\ \text { DOE/NV } & \text { U.S. Department of Energy, Nevada Operations Office } \\ \text { EPA } & \text { U.S. Environmental Protection Agency } \\ \mathrm{ft} & \text { foot (feet) } \\ \text { in } & \text { inch(es) } \\ \mathrm{km} & \text { kilometer(s) } \\ \mathrm{m} & \text { meter(s) } \\ \mathrm{mi} & \text { mile(s) } \\ \text { Ml } & \text { local Richter Magnitude } \\ \text { NDEP } & \text { Nevada Division of Environmental Protection } \\ \text { NNSA/NSO } & \text { U.S. Department of Energy, National Nuclear Security Administration } \\ & \text { Nevada Site Office } \\ \text { RCRA } & \text { Resource Conservation and Recovery Act }\end{array}$


Post-Closure Report - CAU 92

Revision: 0

Date: March 2005

THIS PAGE INTENTIONALLY LEFT BLANK 
This Post-Closure Inspection Report provides an analysis and summary of inspections for Corrective Action Unit (CAU) 92, Area 6 Decon Pond Facility, Nevada Test Site, Nevada. CAU 92 was closed in accordance with the Resource Conservation and Recovery Act (RCRA) Part B Operational Permit (Nevada Division of Environmental Protection, 1995) and the Federal Facility Agreement and Consent Order of 1996 on May 11, 1999. CAU 92 consists of two Corrective Action Sites (CASs): CAS 06-04-01, Decon Pad Oil/Water Separator; and CAS 06-05-02, Decontamination Pond (RCRA). Both CASs have use restrictions; however, only CAS 06-05-02, Decontamination Pond (RCRA), requires post-closure inspections. CAS 06-04-01, Decon Pad Oil/Water Separator, is located inside the fence at the Building 6-605 compound. This report covers the annual period January 2004 through December 2004.

Site inspections of the CAU 92 RCRA cover and fencing are performed quarterly. Copies of the inspection checklists are included in Appendix A. A subsidence survey is performed once a year. Additional inspections are conducted if either of the following occurs:

- Precipitation in excess of 1.28 centimeters $(\mathrm{cm})(0.50$ inches [in]) in a 24-hour period

- $\quad$ An earthquake with a magnitude exceeding 4.5 on the local Richter Magnitude (Ml) within 100 kilometers $(\mathrm{km})(62$ miles [mi]) of the unit

Quarterly site inspections were performed in March, June, September, and December of 2004. All observations indicated the continued integrity of the unit. No issues or concerns that could affect the integrity of the unit were noted. All site inspections verified that the integrity of the cover is excellent, the condition of the fencing and signs is good, and the use restrictions have been maintained. Copies of the inspection checklists and field notes are included in Appendix A.

There was one seismic event with a magnitude exceeding $4.5 \mathrm{Ml}$ during this reporting period. An earthquake measuring 4.6 Ml occurred on May 16, 2004, slightly more than $100 \mathrm{~km}$ (62 mi) from CAU 92, which is the maximum distance that requires an inspection. Even though the earthquake occurred farther away from the closure than the requirements for an inspection specify, an inspection was performed on May 18, 2004, as a best management practice. No issues or concerns were noted, and the unit remains in excellent condition.

There were seven precipitation events that exceeded $1.28 \mathrm{~cm}(0.50 \mathrm{in})$ within a 24-hour period during this reporting period: February 2-3, February 22-23, March 1-2, October 19-20, October 27-28, November 7-8, and December 28-29, 2004. Following each of these precipitation events, a site inspection was performed. No significant changes in site conditions were noted during these inspections, and the condition of the unit remains excellent. Copies of the inspection checklists and field notes are included in Appendix A. Precipitation records for January 2004 through December 2004 are included in Appendix C.

A subsidence survey was completed on December 14, 2004. No significant change in any of the monument elevations was evident. 
Post-Closure Report - CAU 92

Revision: 0

Date: March 2005

THIS PAGE INTENTIONALLY LEFT BLANK 


\subsection{INTRODUCTION}

\subsection{SCOPE AND OBJECTIVES}

Corrective Action Unit (CAU) 92, Area 6 Decon Pond Facility, is located in Area 6 of the Nevada Test Site, Nevada, adjacent to the Decontamination Facility along the southern portion of the Yucca Lake Dry Playa (Figure 1). CAU 92 is identified in the Federal Facility Agreement and Consent Order (FFACO) of 1996 and was closed in accordance with the Resource Conservation and Recovery Act (RCRA) Part B Operational Permit (Nevada Division of Environmental Protection [NDEP], 1995). CAU 92 consists of two Corrective Action Sites (CASs): CAS 06-04-01, Decon Pad Oil/Water Separator; and CAS 06-05-02, Decontamination Pond (RCRA). This report provides an analysis and summary of the quarterly site inspections performed at CAU 92 for the period January 2004 through December 2004.

\subsection{Site HistoRY}

The Area 6 Decon Pond Facility was constructed and became operational in 1979. It was a square unit, approximately 60 meters $(\mathrm{m})$ (200 feet [ft]) long on each interior side, with perimeter berms $1.5 \mathrm{~m}(5 \mathrm{ft})$ above the surrounding grade. A discharge pipe from the Decon Pad Oil/Water Separator (CAS 06-04-01) entered the Decontamination Pond (CAS 06-05-02) on the southwest side, approximately $0.3 \mathrm{~m}(1 \mathrm{ft})$ above the base of the pond. The Decontamination Pond was unlined and was surrounded by an earthen berm on all four sides with a two-to-one grade (U.S. Department of Energy, Nevada Operations Office [DOE/NV], 1996).

The Decon Pond Facility was used for the disposal of partially treated liquid effluent discharged from Buildings 6-605 (Decontamination Facility) and 6-607 (Industrial Laundry). Effluent from Buildings 6-605 and 6-607 was piped into the Decontamination Pad Oil/Water Separator and then to the Decontamination Pond where it was allowed to evaporate.

Radioactively contaminated site worker clothing (e.g., coveralls, gloves, and boot covers) were processed in the laundry in Building 6-607. The laundry process used standard industrial water softeners and laundry detergents to decontaminate the personal protective equipment. Heavy equipment and critical tolerance equipment used in weapons testing were processed in Building 6-605 to remove radioactive contamination. This equipment was treated using degreasers, caustic or acid solutions, and detergents and then spray washed with pressurized hot water. The wash water was collected in floor drains and piped through a sand filter/separator. This partially treated water also fed into the Decon Pad Oil/Water Separator and then discharged into the Decontamination Pond.

Suspected RCRA regulated hazardous waste or hazardous waste constituents released into the Decontamination Pond included degreasing solvents associated with equipment decontamination activities (chlorobenzene and 1,1,1-trichlorethane), petroleum hydrocarbon constituents (xylenes), and heavy metals (lead and arsenic). Releases of RCRA-regulated hazardous waste or hazardous waste constituents have not been discharged to the Decontamination Pond since 1988 (DOE/NV, 1996). The following radionuclides were detected: cobalt-60, cesium-137, plutonium-238, and tritium. A detailed discussion of the unit activities and analytical results can be found in the CAU 92 Characterization Report (DOE/NV, 1997a). 


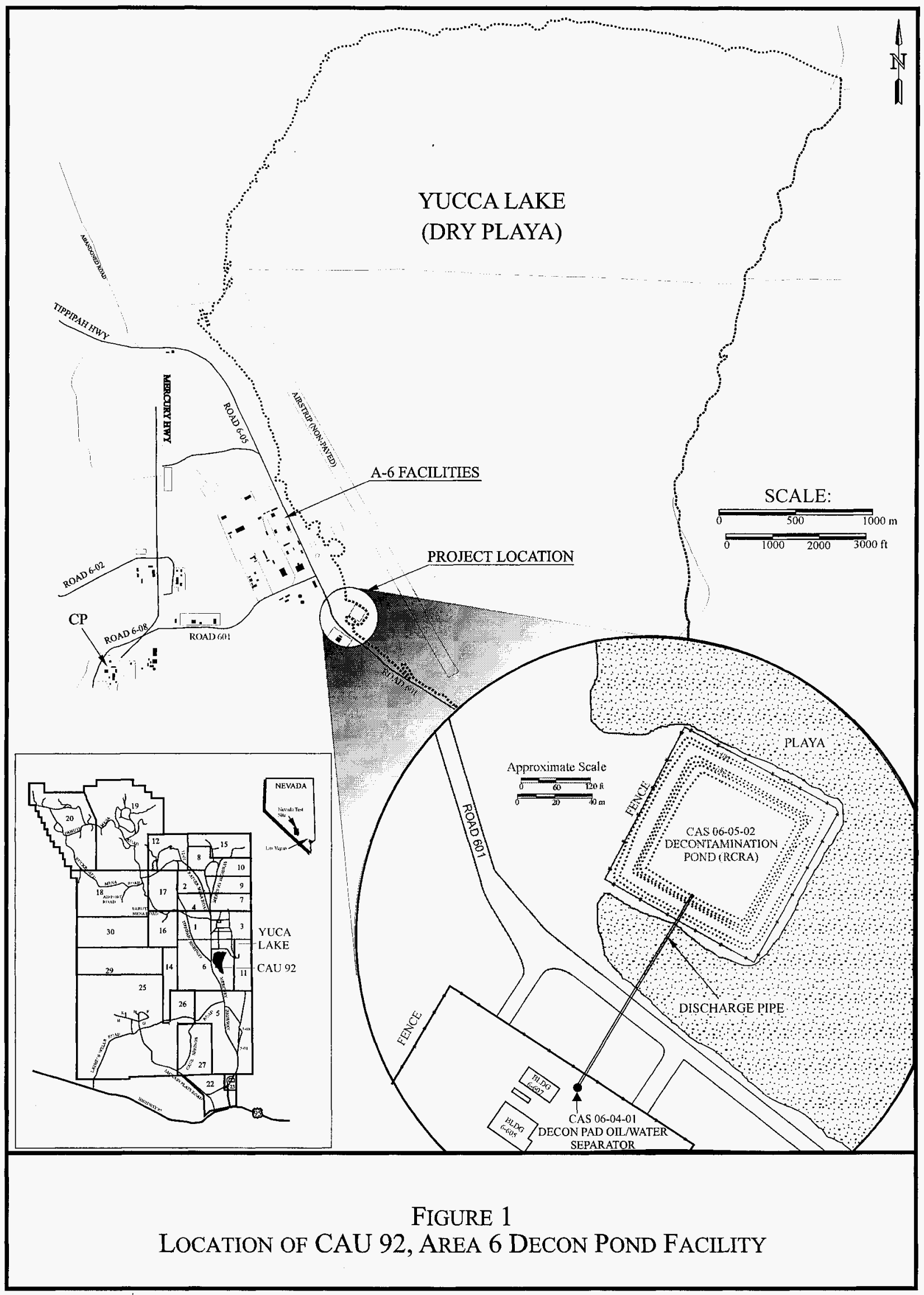


CAS 06-05-02, Decontamination Pond (RCRA), was closed by constructing an engineered cover (DOE/NV, 1999). The earthen berms were pushed into the pond and compacted. Additional materials were imported to form subsequent layers and compacted to meet specifications. The final layers consist of a bedding layer, geosynthetic clay liner, buffer layer, and an erosion control layer. The cover was designed to meet or exceed all requirements specified in 40 Code of Federal Regulations (CFR) §265.228(a)(2) (U.S. Environmental Protection Agency [EPA], 1996a). Monuments were placed on the cover to monitor subsidence, and a chain-link fence surrounds the cover to limit access. CAS 06-04-01, Decon Pad Oil/Water Separator, was closed by backfilling with grout.

All closure activities performed at CAU 92 were completed on February 16, 1999. The Closure Report (DOE/NV, 1999) was approved and a Notice of Completion for CAU 92 was issued by the NDEP on May 11, 1999. Table 1 summarizes the chronology of significant events over the life span of the facility. 
Table 1: Chronology of the ARea 6 Decon Pond Facility

\begin{tabular}{|c|c|}
\hline DATE & SIGNIFICANT EVENTS \\
\hline 1979 & The Decontamination Pond was constructed and became operational. \\
\hline $1979-1988$ & $\begin{array}{l}\text { The facility received partially treated liquid effluents from Building 6-605 } \\
\text { (Decontamination Facility) and Building 6-607 (Industrial Laundry) prior to the } \\
\text { implementation of administrative controls on the use of RCRA regulated materials. }\end{array}$ \\
\hline 1990 & $\begin{array}{l}\text { A clay discharge pipe from Building } 6-605 \text { was broken during a trenching operation. An } \\
\text { unknown amount of effluent was released to the subsurface soil. }\end{array}$ \\
\hline 1991 & $\begin{array}{l}\text { On March 3, the northwest side of the earthen berm was reportedly breeched due to an } \\
\text { intense rainstorm and high winds with effluent spilling onto the Yucca Lake Playa. }\end{array}$ \\
\hline 1992 & $\begin{array}{l}\text { The Decontamination Pond was removed from service and all known access lines were } \\
\text { plugged and rerouted to aboveground tanks. }\end{array}$ \\
\hline 1996 & $\begin{array}{l}\text { Closure activities began with the submission and approval of the Resource Conservation } \\
\text { and Recovery Act Industrial Site Environmental Restoration Site Characterization Plan } \\
\text { Area 6 Decontamination Pond Facility (DOE/NV, 1996). }\end{array}$ \\
\hline \multirow{3}{*}{1997} & $\begin{array}{l}\text { A characterization program to obtain samples for radiological, chemical, and geotechnical } \\
\text { parameters was conducted from May to June. }\end{array}$ \\
\hline & $\begin{array}{l}\text { The Resource Conservation and Recovery Act Industrial Site Environmental Restoration } \\
\text { Site Characterization Report, Area } 6 \text { Decontamination Pond Facility, Corrective Action } \\
\text { Unit No. } 92 \text { (DOE/NV, 1997a) was issued. }\end{array}$ \\
\hline & $\begin{array}{l}\text { The Resource Conservation and Recovery Act Corrective Measures Study, Area } 6 \\
\text { Decontamination Pond Facility. Corrective Action Unit No. } 92 \text { (DOE/NV, 1997b) was } \\
\text { issued. }\end{array}$ \\
\hline \multirow[t]{2}{*}{1998} & $\begin{array}{l}\text { The Closure Plan for Corrective Action Unit 92: Area } 6 \text { Decontamination Pond, Nevada } \\
\text { Test Site. Nevada (DOE/NV, 1998) was issued. }\end{array}$ \\
\hline & Closure activities began on July 30. \\
\hline \multirow{4}{*}{1999} & The closure was completed on February 16. \\
\hline & $\begin{array}{l}\text { The Closure Report for Corrective Action Unit 92: Area } 6 \text { Decontamination Pond, Nevada } \\
\text { Test Site. Nevada (DOE/NV, 1999) was issued. }\end{array}$ \\
\hline & $\begin{array}{l}\text { The Closure Report was approved and a Notice of Completion issued by NDEP on } \\
\text { May } 11 .\end{array}$ \\
\hline & Quarterly inspections began in March. \\
\hline
\end{tabular}




\subsection{REGULATORY CRITERIA}

Post-closure inspections of CAU 92, Area 6 Decon Pond Facility, are required under 40 CFR $\$ 265.310$ (b) (EPA, 1996b). Post-closure groundwater monitoring requirements specified in the 40 CFR $\$ 265.310$ have been waived based on 40 CFR $\$ 265.90$ (EPA, 1996c). The post-closure care required for the cover is specified in Section VII.B.5.c of the RCRA Part B Permit NEV HW009 (NDEP, 2000).

Inspections are conducted quarterly. Additional site inspections will be performed if either of the following occurs:

- $\quad$ Precipitation in excess of 1.28 centimeters $(\mathrm{cm})(0.50$ inches [in]) in a 24 -hour period

- $\quad$ An earthquake with a magnitude exceeding 4.5 on the local Richter Magnitude (Ml) within 100 kilometers $(\mathrm{km})(62$ miles [mi]) of the closure.

Post-closure inspections consist of and adhere to the following:

- $\quad$ During each inspection, the condition of the RCRA cover and fencing will be determined. The perimeter of the fencing will be walked by the inspector, and the condition of the wave barrier (fiberglass slats laced through the bottom of the chain-link fencing), warning signs, entrance gate, and lock will be documented.

- The condition of the five survey subsidence monuments will be inspected. Once a year, the five subsidence monuments will be surveyed to determine if the RCRA cover has subsided.

- During each inspection, any changes in the condition of the cover or fenced area will be documented. The reason for the inspection (i.e., quarterly, excess precipitation, or earthquake) will be noted on the inspection report. Specific changes noted on the current condition of the cover include, but are not limited to, trash and debris within the fences area, vegetation growing on the cover, animal burrows/nesting activity, or erosion of the cover.

- Small cracks or settling imperfections (less than $5 \mathrm{~cm}$ [2 in] deep) on the cover will be documented and will be scheduled for repair on an annual basis. Larger disruptions of the cover will be immediately evaluated and remedied within 60 days of discovery and shall be reported immediately to NDEP.

- All repair work should preserve the original RCRA cover "as-built" design. If the cover repair requires modification of the RCRA cover design, the U.S. Department of Energy, National Nuclear Security Administration Nevada Site Office (NNSA/NSO) will present a formal design modification request to NDEP prior to making the design modification. 
Post-Closure Report - CAU 92

Revision: 0

Date: March 2005

THIS PAGE INTENTIONALLY LEFT BLANK 


\subsection{SITE INSPECTION AND SUBSIDENCE SURVEY RESULTS}

A subsidence survey was performed on December 14, 2004. Quarterly post-closure inspections of CAU 92 for the annual period January 2004 through December 2004 were conducted on March 22, June 23, September 14, and December 14, 2004. One seismic-triggered inspection and seven precipitation-triggered inspections were performed. Copies of the inspection checklists and field notes are included in Appendix A. Site photographs are included in Appendix B.

\subsection{SUBSIDENCE SURVEY}

A survey of the five subsidence monuments at CAU 92 was conducted on December 14, 2004. To determine if the cover had subsided, the survey results were compared to the baseline survey results obtained on December 17, 1998. The results are summarized in Table 2.

The subsidence survey indicates no appreciable change in the elevation of any of the five subsidence monuments from the initial survey of December 1998. Reported variations are within instrument and method accuracy. Inspections of the cover also indicate no cracking or signs of settling or subsidence of the cover.

Table 2: Subsidence Monument Survey Elevations

\begin{tabular}{|c|c|c|}
\hline \multirow{2}{*}{ MONUMENT NUMBER } & \multicolumn{2}{|c|}{ ELEVATION AT TOP OF MONUMENT ${ }^{1}(\mathrm{~m})$} \\
\hline & $\begin{array}{c}\text { DECEMBER } 1998 \\
\text { (Baseline) }\end{array}$ & DECEMBER 2004 \\
\hline 1 & $1,196.065$ & $1,196.065$ \\
\hline 2 & $1,195.294$ & $1,195.296$ \\
\hline 3 & $1,195.321$ & $1,195.321$ \\
\hline 4 & $1,195.290$ & $1,195.293$ \\
\hline 5 & $1,195.345$ & $1,195.348$ \\
\hline
\end{tabular}

'Elevations based on the North American Vertical Datum of 1929 in meters.

\subsection{QUARTERLY INSPECTION RESULTS}

\subsubsection{First Quarter}

The first quarter inspection was conducted on March 22, 2004. The inspection indicated desiccation cracking along the edges of the unit, but not on the cover itself. Rivulets were also noted along the west edge within the fence line. These features do not affect the integrity of the unit, but should be monitored closely for changes. A small amount of dead vegetation was noted in the windward corners of the fence.

All observations indicate the continued integrity of the cover and appurtenances. 


\subsubsection{Second Quarter}

The second quarter inspection was conducted on June 23, 2004. No change was evident in the desiccation cracking and rivulets along the edges of the unit since the last inspection. These features do not affect the integrity of the unit, but should continue to be monitored closely for changes.

All observations indicate the continued integrity of the cover and appurtenances.

\subsubsection{Third Quarter}

The third quarter inspection was conducted on September 14, 2004. No changes in the severity or extent of the desiccation cracking and rivulets along the edges of the unit were noted since the last inspection. A small amount of debris and dead vegetation had accumulated in the windward corners of the fence. The wave barrier (fiberglass slats laced through the bottom of the chainlink fencing) is slightly damaged and should be repaired as soon as practical.

All observations indicate the continued integrity of the cover and appurtenances.

\subsubsection{Fourth Quarter}

The fourth quarter inspection was conducted on December 14, 2004. No changes in the severity or extent of the desiccation cracking and rivulets along the edges of the unit were noted since the last inspection. The wave barrier was repaired and is in good condition. Some of the chainlink sections on the northwest side of the fence have come loose from the supporting posts, and will be repaired as soon as practical.

All observations indicate the continued integrity of the cover and appurtenances.

\subsection{SEISMIC TRIGGERED INSPECTION RESULTS}

There was one seismic event with a magnitude exceeding $4.5 \mathrm{Ml}$ during this reporting period. An earthquake measuring 4.6 Ml occurred on May 16, 2004, slightly more than $100 \mathrm{~km}$ (62 mi) from CAU 92, which is the maximum distance that requires an inspection. Even though the earthquake occurred farther away from the site than the requirements for an inspection specify, an inspection was performed on May 18, 2004, as a best management practice. No issues or concerns were noted.

\subsection{PRECIPITATION TRIgGERED INSPECTION RESUltS}

There were seven precipitation events that exceeded $1.28 \mathrm{~cm}(0.50 \mathrm{in})$ within a 24-hour period during this reporting period. Precipitation records for January 2004 through December 2004 are included in Appendix C. Following each of these precipitation events, a site inspection was performed. No significant changes in site conditions were noted during the precipitation event inspections. The following weather-triggered inspections were performed:

- A precipitation event measured at $1.80 \mathrm{~cm}$ (0.71 in) occurred on February 2-3, 2004. An inspection was performed on February 5, 2004. No issues or concerns were noted. 
- A precipitation event measured at $1.78 \mathrm{~cm}$ (0.69 in) occurred on February 22-23, 2004. An inspection was performed on February 23, 2004. No issues or concerns were noted.

- A precipitation event measured at $1.47 \mathrm{~cm}(0.58 \mathrm{in})$ occurred on March 1-2, 2004. An inspection was performed on March 3, 2004. No issues or concerns were noted.

- A precipitation event measured at $4.39 \mathrm{~cm}$ (1.72 in) occurred on October 19-20, 2004. An inspection was performed on October 21, 2004. No issues or concerns were noted.

- A precipitation event measured at $2.10 \mathrm{~cm}(0.83 \mathrm{in})$ occurred on October 27-28, 2004. An inspection was performed on November 1,2004. No issues or concerns were noted.

- $\quad$ A precipitation event measured at $1.78 \mathrm{~cm}(0.70$ in) occurred on November 7-8, 2004. An inspection was performed on November 9, 2004. No issues or concerns were noted.

- A precipitation event measured at $2.51 \mathrm{~cm}$ (1.28 in) occurred on December 28-29, 2004. An inspection was performed on December 29, 2004. No issues or concerns were noted.

All inspections due to excessive precipitation were performed in compliance with the Hazardous Waste Facility Permit NEV HW009 VII.5.b.i.A. 
Post-Closure Report - CAU 92

Revision: 0

Date: March 2005

\section{THIS PAGE INTENTIONALLY LEFT BLANK}




\subsection{SUMMARY, CONCLUSIONS, AND RECOMMENDATIONS}

\subsection{SUMMARY AND CONCLUSIONS}

The post-closure inspections conducted in 2004 have demonstrated the continued integrity of the cover, fencing, warning signs, and use restriction. The subsidence survey indicates no settling or subsidence of the cover since the 1998 elevation survey. The site closure is performing as designed.

\subsection{RECOMMENDATIONS}

- $\quad$ Continue post-closure inspections as scheduled.

- Monitor for changes in the desiccation cracking and rivulets present on the cover side slopes.

- $\quad$ Reattach chainlink fence to posts on the northwest side of the unit. 
Post-Closure Report - CAU 92

Revision: 0

Date: March 2005

\section{THIS PAGE INTENTIONALLY LEFT BLANK}




\subsection{REFERENCES}

DOE/NV, see U.S. Department of Energy, Nevada Operations Office.

EPA, see U.S. Environmental Protection Agency.

FFACO, see Federal Facility and Consent Order.

Federal Facility Agreement and Consent Order. 1996 (as amended). Agreed to by the State of Nevada, U.S. Department of Energy, and U.S. Department of Defense.

Nevada Division of Environmental Protection. 1995. Nevada Division of Environmental Protection Permit for a Hazardous Waste Management Facility, Permit Number NEV HW009, Carson City, NV.

Nevada Division of Environmental Protection. 2000. Nevada Division of Environmental Protection Permit for a Hazardous Waste Management Facility, Permit Number NEV HW009, Carson City, NV.

U.S. Department of Energy, Nevada Operations Office. 1996. Resource Conservation and Recovery Act Industrial Site Environmental Restoration Site Characterization Plan Area 6 Decontamination Pond Facility, Revision 1, DOE/NV--438. Las Vegas, NV.

U.S. Department of Energy, Nevada Operations Office. 1997a. Resource Conservation and Recovery Act Industrial Site Environmental Restoration Site Environmental Restoration Site Characterization Report, Area 6 Decontamination Pond Facility, Corrective Action Unit No. 92, Revision 1, DOE/NV--470. Las Vegas, NV.

U.S. Department of Energy, Nevada Operations Office. 1997b. Resource Conservation and Recovery Act Corrective Measures Study, Area 6 Decontamination Pond Facility, Corrective Action Unit No. 92, DOE/NV--493. Las Vegas, NV.

U.S. Department of Energy, Nevada Operations Office. 1998. Closure Plan for Corrective Action Unit 92: Area 6 Decontamination Pond, Nevada Test Site, Nevada, Revision 2, DOE/NV/11718--256-Rev 2. Las Vegas, NV.

U.S. Department of Energy, Nevada Operations Office. 1999. Closure Report for Corrective Action Unit 92: Area 6 Decontamination Pond, Nevada Test Site, Nevada, DOE/NV/11718--306. Las Vegas, NV.

U.S. Environmental Protection Agency. 1996a. 40 Code of Federal Regulations 265.228 Interim Status Standards for Owners and Operators of Hazardous Waste Treatment, Storage, and Disposal Facilities, Washington, D.C. 
U.S. Environmental Protection Agency. 1996b. 40 Code of Federal Regulations 265.310 Interim Status Standards for Owners and Operators of Hazardous Waste Treatment, Storage, and Disposal Facilities, Washington, D.C.

U.S. Environmental Protection Agency. 1996c. 40 Code of Federal Regulations 265.90 Interim Status Standards for Owners and Operators of Hazardous Waste Treatment, Storage, and Disposal Facilities, Washington, D.C. 
Post-Closure Report - CAU 92

Revision: 0

Date: March 2005

\section{APPENDIX A}

\section{INSPECTION CHECKLISTS AND FIELD NOTES}


Post-Closure Report - CAU 92

Revision: 0

Date: March 2005

THIS PAGE INTENTIONALLY LEFT BLANK 


\section{CAU 92: AREA 6 DECON POND FACILITY, POST-CLOSURE INSPECTION CHECKLIST}

\begin{tabular}{||l|l|l|}
\hline \hline \multicolumn{2}{|l|}{ Inspection Date and Time: $3 / 22 / 2004,12: 30 \mathrm{pm}$} & Reason for Inspection: Quarterly \\
\hline Date of Last Post-Closure Inspection: $12 / 22 / 2003$ & Reason for Last Post-Closure Inspection: Quarterly \\
\hline \multicolumn{2}{|l|}{ Responsible Agency: Bechtel Nevada Environmental Restoration } & \\
\hline Address: Nevada Test Site, Mercury, Nevada & Title: Field Coordinator & Organization: Environmental Restoration \\
\hline Responsible Agency Official: Jeffrey L. Smith. Project Manager & Organization: N/A \\
\hline Chief Inspector: James Traynor & Title: N/A & \\
\hline Assistant Inspector: N/A &
\end{tabular}

\section{A. GENERAL INSTRUCTIONS}

1. All checklist items must be completed and detailed comments made to document the results of the site inspection. The completed checklist is part of the field record of the inspection. Additional pages should be used as necessary to ensure that a complete record is made. Attach the additional pages and number all pages upon completion of the inspection.

2. Any checklist line item marked by an inspector in a SHADED BOX must be filly explained or an appropriate reference to previous reports provided. The purpose of this requirement is to provide a written explanation of inspector observations and the inspector's rationale for conclusions and recommendations. Explanations are to be placed on additional attachments and cross-referenced appropriately. Explanations, in addition to narrative, will take the form of sketches, measurements, and annotated site maps.

3. The site inspection is a walking inspection of the entire site including the perimeter and sufficient transects to be able to inspect the entire surface and all features specifically described in this checklist.

4. A standard set of color photographs is required. In addition, all anomalous features or new features (suoh as changes in adjacent area land use) are to be photographed. A photograph log entry will be made for each photograph taken.

5. Field notes taken to assist in completion of this checklist will become part of the inspection record. No form is specified for field notes; however, they must be legible and in sufficient detail to enable review by succeeding inspectors and the responsible agency.

6. This unit will be inspected quarterly with formal reporting to the Nevada Division of Environmental Protection to be done annually. The annual report will include an executive summary, this inspection checklist with field notes and photograph log attached, and recommendations and conclusions.

\begin{tabular}{|c|c|c|c|}
\hline B. PREPARATION ('To be competed prior to site visit) & YES & NO & EXPLANATION \\
\hline 1. Has the Post-Closure Permit been reviewed? & $\mathrm{x}$ & 13 & \\
\hline 2. Have the design basis documents been reviewed? & $\mathrm{x}$ & & \\
\hline 3. Have the site as-built plans and site base map been reviewed? & $x$ & & \\
\hline 4. Have the previous inspection reports been reviewed? & $\mathrm{X}$ & & \\
\hline $\begin{array}{l}\text { a. Were anomalies or trends detected on previous } \\
\text { inspections? }\end{array}$ & $\mathrm{x}$ & & $\begin{array}{l}\text { Desiccation cracking along edges of unit. After heavy precipitation } \\
\text { ponding along edges of unit. }\end{array}$ \\
\hline b. Was maintenance performed? & & $\mathrm{x}$ & \\
\hline 5. Have the site maintenance and repair records been reviewed? & $\mathrm{x}$ & & \\
\hline $\begin{array}{l}\text { a. Has site repair resulted in a change from as-built } \\
\text { conditions? }\end{array}$ & & $\mathrm{X}$ & \\
\hline $\begin{array}{l}\text { b. Are revised as-built plans available that reflect repair } \\
\text { changes? }\end{array}$ & & $\mathrm{x}$ & $\mathrm{N} / \mathrm{A}$ \\
\hline
\end{tabular}

\section{SITE INSPECTION PREPARATION}

Assemble the following, as needed, to conduct inspections:

a. Camera, film, and batteries

b. Keys to locks

c. Clipboard

d. Tape measure

e. Radio, pager, etc.

f. Previous Post-Closure Report, Inspection Checklists, repair records, and as-built plans

g. Other miscellaneous support equipment 
CAU 92: AREA 6 DECON POND FACILITY, POST-CLOSURE INSPECTION CHECKLIST

\begin{tabular}{|l|l|l|l|l|}
\hline \hline D. SITE INSPECTION & YES & NO & EXPLANATION \\
\hline
\end{tabular}

1. Adjacent off-site features:

a. Have there been any changes in the use of the adjacent area?

b. Are there any new roads or trails?

c. Has there been any change in the position of nearby -washes?

d. Has there been lateral excursion or erosion/deposition of nearby wasises?

e. Are there new drainage channels?

f. Has there been a change in the surrounding vegetation?

\begin{tabular}{|c|c|l|}
\hline & $x$ & \\
\hline & $x$ & \\
\hline & $x$ & \\
\hline & $x$ & \\
\hline & $x$ & \\
\hline & $x$ & \\
\hline
\end{tabular}

2. Access roads. fences. gates, and signs:

a. Is there a break in the fence?

b. Have any posts been damaged or their anchoring weakened?

c. Does the gate show evidence of tampering or damage?

d. Was the gate locked?

e. Is there any evidence of human intrusion onto the cover?

f. Is there any evidence of large animal intrusion onto the cover?

g. Have any signs been damaged or removed?

Number of signs replaced:

h. Other?

\begin{tabular}{|r|c|c|}
\hline & $X$ & \\
\hline & $X$ & \\
\hline & $X$ & \\
\hline$X$ & & \\
\hline & $X$ & \\
\hline & $X$ & \\
\hline & $X$ & \\
\hline & $X$ & \\
\hline
\end{tabular}

3. Monuments and other permanent features:

a. Have survey markers, boundary monuments, or monitoring stations been disturbed?

b. Do natural processes threaten the integrity of any survey marker, boundary monument or monitoring station?

c. Is there excessive vegetation around the survey markers, boundary monuments, or monitoring stations?

d. Other?

\begin{tabular}{|r|l|l|}
\hline & $X$ & \\
\hline & $X$ & \\
\hline & $X$ & \\
\hline & $X$ \\
\hline & $X$ & \\
\hline
\end{tabular}

4. Waste unit cover:

a. Is there evidence of settling?

b. Is there evidence of cracking?

c. Is there evidence of erosion (wind or water)?

d. Is there evidence of animal burrowing?

e. Is there vegetation growing on the cover?

g. Other (including trash, debris, etc within fenced area)?

\begin{tabular}{|r|l|l|}
\hline $\mathrm{X}$ & $\mathrm{X}$ & \\
\hline $\mathrm{X}$ & & $\begin{array}{l}\text { Desiccation aiong edges of unit (not on unit) should not affect the } \\
\text { integrity of the unit. }\end{array}$ \\
\hline $\mathrm{X}$ & $\mathrm{X}$ & \\
\hline & $\mathrm{X}$ & \\
\hline $\mathrm{X}$ & & $\begin{array}{l}\text { A smalets along west edge not on unit but within fenceline. } \\
\text { the corners of the unit. }\end{array}$ \\
\hline
\end{tabular}




\section{CAU 92: AREA 6 DECON POND FACILITY, POST-CLOSURE INSPECTION CHECKLIST}

5. Photograph Instructions:

A total of 8 photographs are required to be taken during each inspection of CAU 92. Additional photographs may also be taken. The required photographs shall be taken as follows:

- Four (4) from the center of the unit, one in each compass direction (i.e., N, S, E, W) and

- Four (4) of the unit from outside the fence, one in each compass direction.

6. Photograph Documentation:

a. Have all photographs required by the photograph instructions been taken?

b. Has a photograph log been prepared? (Number of photograpls taken: 8 )

c. Other?

\begin{tabular}{|c|c|c|}
\hline YES & NO & EXPLANATION \\
\hline $\mathrm{X}$ & & \\
\hline $\mathrm{X}$ & & \\
\hline & $\mathrm{X}$ & \\
\hline
\end{tabular}

\section{E. FIELD ÇONCLUSIONS}

1. Is there an imminent hazard to the integrity of the unit? (Immediate report required)

$\mathrm{X}$

Person/Agency to whom report was made:

\begin{tabular}{||l|c|c|c|}
\hline 2. Are more frequent inspections required? & & $\mathrm{X}$ & \\
\hline 3. Are existing maintenance/repair actions satisfactory? & $\mathrm{X}$ & & \\
\hline 4. Is other maintenance/repair necessary? & & $\mathrm{X}$ & \\
\hline
\end{tabular}

5. Field conclusions/recommendations: All observations indicate continued integrity of the cover and appurtenances.

\section{F. CERTIFICATION}

I have conduction an inspection of CAU 92, Area 6 Decon Pond Facility, in accordance with the procedures of the Post-Closure Permit (including the PostClosure Plan) as recorded on this ghecklist atached sheets, field notes, photographs, and photograph logs.

Chief Inspector's Signature:

Printed Name: James Traynof

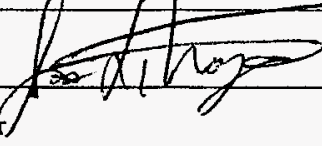

Date: $3 / 22 / 2004$

Title: Field Coordinator 
66 TITLE

PROJECT NO.

Work continued from Page

BOOK NO.

CAV 92 Areal Deon Pond Facility

CA 506-05-02 Decontamination Fond

$12 \frac{30}{}$ Adjacent

AccessRcads, Fences, Gates, y Sighs: Good

Monivinants tother permanent features: Gocolo

Anat Cover: Good. Dead, crumbling vigatatos

Photos: 1 outside $N$ cover.

$\begin{array}{ll}2 \text { outside } & 5 \text { inside } \\ 3 \text { outsides } & 7 \text { insides } \\ 4 \text { outside } & 8 \text { insider }\end{array}$

Recommendations Conclusions: Dunt is in good condition Continue inspections as scheduled.

CAVII2 Area 23 Hazardous Waste Trenches CAS 23-21-02 Area 23 Haze waste Trenches.

$143^{\circ}$ Adjacent Offsite: Good.

Access Roads, Fences, Gates, 4 Sighs: Good.

Monumatsy other Permanent structives:Gcodo

Covers Trenches: Minor vegetation.

Recominneidations / Conchisfons: Cover 4 remainder of Vat is in good condition. Canine inspections as scheduled.

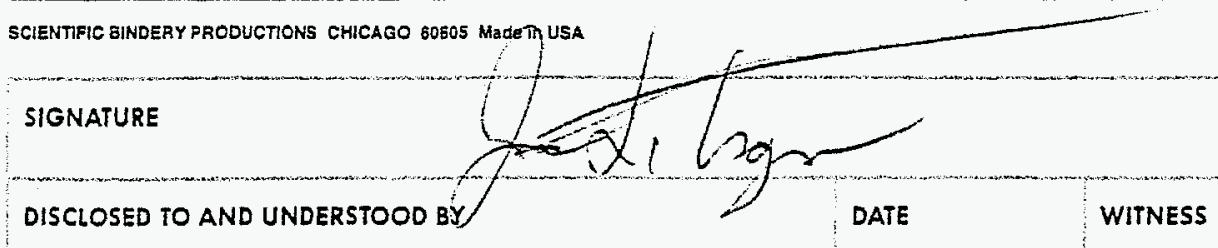

Work continued to Page

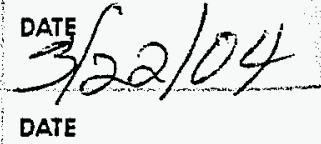




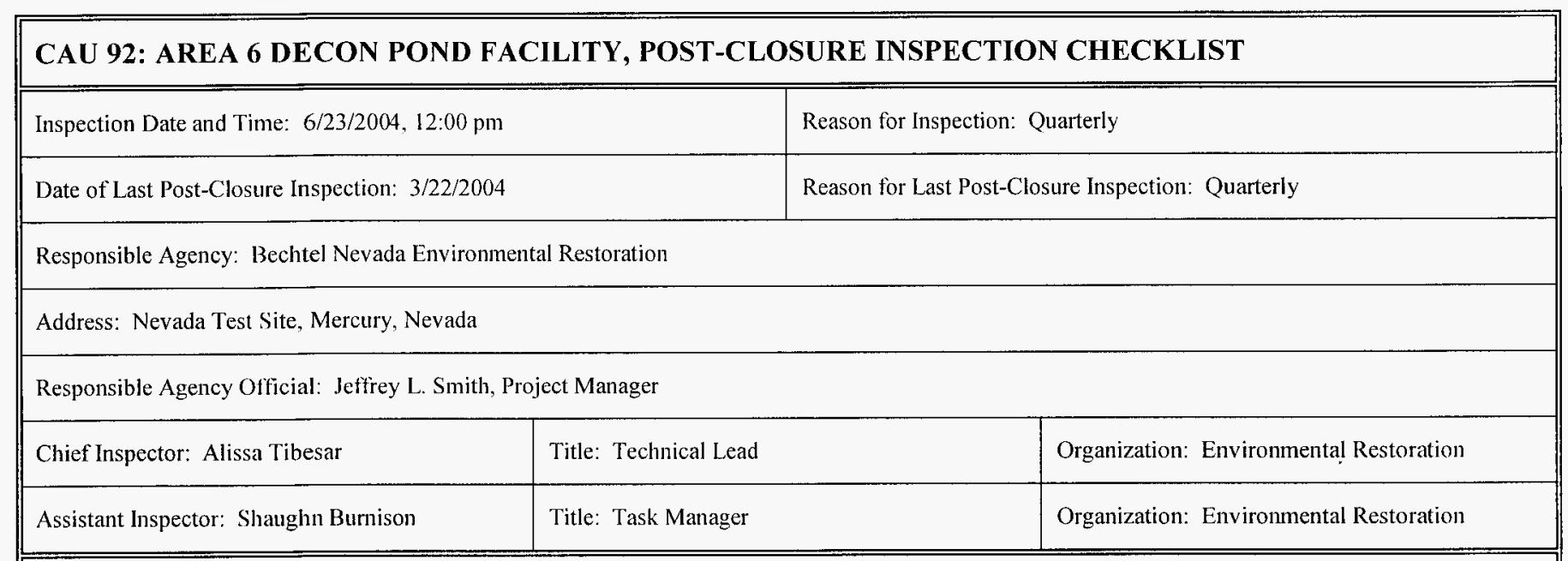

\section{A. GENERAL INSTRUCTIONS}

1. All checklist items must be completed and detailed comments made to document the results of the site inspection. The completed checklist is part of the field record of the inspection. Additional pages should be used as necessary to ensure that a complete record is made. Attach the additional pages and number all pages upon completion of the inspection.

2. Any checklist line item marked by an inspector in a SHADED BOX must be fully explained or an appropriate reference to previous reports provided. The purpose of this requirement is to provide a written explanation of inspector observations and the inspector's rationale for conclusions and recommendations. Explanations are to be placed on additional attachments and cross-referenced appropriately. Explanations, in addition to narrative, will take the form of sketches, measurements, and annotated site maps.

3. The site inspection is a walking inspection of the entire site including the perimeter and sufficient transects to be able to inspect the entire surface and all features specifically described in this checklist.

4. A standard set of color photographs is required. In addition, all anomalous features or new features (such as changes in adjacent area land use) are to be photographed. A photograph log entry will be made for each photograph taken.

5. Field notes taken to assist in completion of this checklist will become part of the inspection record. No form is specified for field notes; however, they must be legible and in sufficient detail to enable review by succeeding inspectors and the responsible agency.

6. This unit will be inspected quarterly with formal reporting to the Nevada Division of Environmental Protection to be done annually. The annual report will include an executive summary, this inspection checklist with field notes and photograph log attached, and recommendations and conclusions.

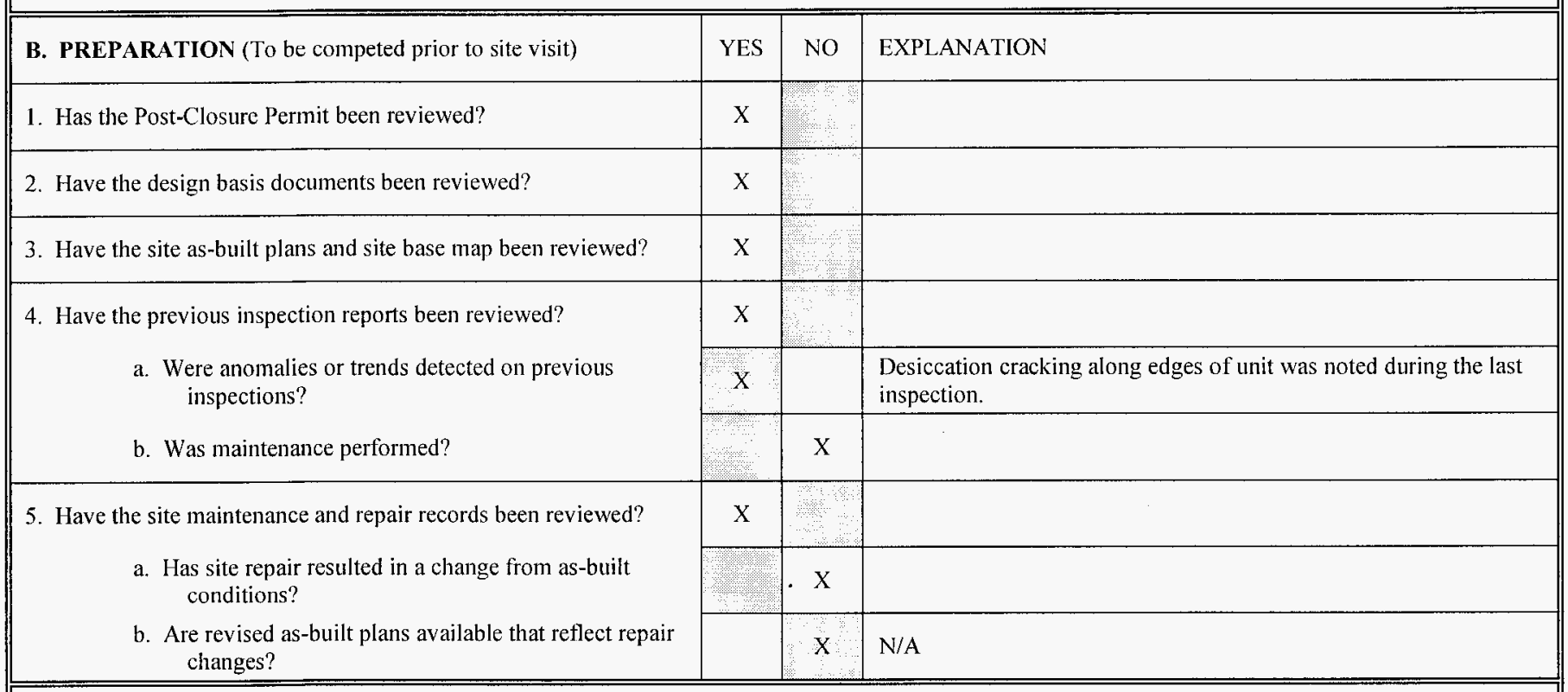

\section{SITE INSPECTION PREPARATION}

Assemble the following, as needed, to conduct inspections:

a. Camera, film, and batteries

b. Keys to locks

c. Clipboard

d. Tape measure

e. Radio, pager, etc.

f. Previous Post-Closure Report, Inspection Checklists, repair records, and as-built plans

g. Other miscellaneous support equipment 


\section{CAU 92: AREA 6 DECON POND FACILITY, POST-CLOSURE INSPECTION CHECKLIST}

\begin{tabular}{|l|l|l|l|l|}
\hline D. SITE INSPECTION & YES & NO & EXPLANATION \\
\hline
\end{tabular}

1. Adjacent off-site features:

a. Have there been any changes in the use of the adjacent area?

b. Are there any new roads or trails?

c. Has there been any change in the position of nearby washes?

d. Has there been lateral excursion or erosion/deposition of nearby washes?

e. Are there new drainage channels?

f. Has there been a change in the surrounding vegetation?

\begin{tabular}{|c|c|l|}
\hline & $\mathrm{X}$ & \\
\hline & $\mathrm{X}$ & \\
\hline & $\mathrm{X}$ & \\
\hline & $\mathrm{X}$ & \\
\hline & $\mathrm{X}$ & \\
\hline & $\mathrm{X}$ & \\
\hline
\end{tabular}

2. Access roads, fences, gates, and signs:

a. Is there a break in the fence?

b. Have any posts been damaged or their anchoring weakened?

c. Does the gate show evidence of tampering or damage?

d. Was the gate locked?

e. Is there any evidence of human intrusion onto the cover?

f. Is there any evidence of large animal intrusion onto the cover?

g. Have any signs been damaged or removed? (Number of signs replaced:

h. Other?

\begin{tabular}{|r|r|l||}
\hline & $X$ & \\
\hline & $X$ & \\
\hline & $X$ & \\
\hline$X$ & & \\
\hline & $X$ & \\
\hline$x$ & $X$ & \\
\hline$x$ & $X$ & \\
\hline & $X$ & \\
\hline
\end{tabular}

3. Monuments and other permanent features:

a. Have survey markers, boundary monuments, or monitoring stations been disturbed?

b. Do natural processes threaten the integrity of any survey marker, boundary monument or monitoring station?

c. Is there excessive vegetation around the survey markers, boundary monuments, or monitoring stations?

d. Other?

\begin{tabular}{|c|c|l|}
\hline & $\mathrm{X}$ & \\
\hline & $\mathrm{X}$ & \\
\hline & $\mathrm{X}$ & \\
\hline & $\mathrm{X}$ & \\
\hline & \\
\hline
\end{tabular}

4. Waste unit cover:
a. Is there evidence of settling?
b. Is there evidence of cracking?
c. Is there evidence of erosion (wind or water)?
d. Is there evidence of animal burrowing?
e. Is there vegetation growing on the cover?
g. Other (including trash, debris, etc within fenced area)?

\begin{tabular}{|c|c|l||}
\hline & $X$ & \\
\hline$X$ & & No change in desiccation along edges of unit since last inspection. \\
\hline $\mathrm{X}$ & & No change in rivulets along west edge of unit since last inspection. \\
\hline $\mathrm{X}$ & $\mathrm{X}$ & \\
\hline & $\mathrm{X}$ & \\
\hline & $\mathrm{X}$ & \\
\hline
\end{tabular}




\section{CAU 92: AREA 6 DECON POND FACILITY, POST-CLOSURE INSPECTION CHECKLIST}

5. Photograph Instructions:

A total of 8 photographs are required to be taken during each inspection of CAU 92. Additional photographs may also be taken. The required photographs shall be taken as follows:

- Four (4) from the center of the unit, one in each compass direction (i.e., N, S, E, W) and

- Four (4) of the unit from outside the fence, one in each compass direction.

6. Photograph Documentation:

a. Have all photographs required by the photograph instructions been taken?

b. Has a photograph $\log$ been prepared?

(Number of photographs taken: $\underline{8}$ )

c. Other?

\begin{tabular}{|c|c|c|}
\hline YES & $\mathrm{NO}$ & EXPLANATION \\
\hline $\mathrm{X}$ & & \\
\hline X & $X$ & $\begin{array}{l}\text { Phutos } 6 \text { and } 8 \text { werc switched in } \\
\text { the report to math the order taken } \\
\text { in tast quantw's inspetion }\end{array}$ \\
\hline
\end{tabular}

\section{E. FIELD CONCLUSIONS}

1. Is there an imminent hazard to the integrity of the unit? (Immediate report required)

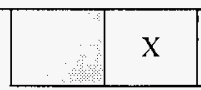

Person/Agency to whom report was made

2. Are more frequent inspections required?

3. Are existing maintenance/repair actions satisfactory?

4. Is other maintenance/repair necessary?

5. Field conclusions/recommendations: No issues or concerns were identified for this site. Continue inspections as planned.

\section{F. CERTIFICATION}

I have conduction an inspection of CAU 92, Area 6 Decon Pond Facility, in accordance with the procedures of the Post-Closure Permit (including the PostClosure Plan) as recorded on this checklist, attached sheets, field notes, photographs, and photograph logs.

Chief Inspector's Signature:

Printed Name: Alissa Tibesar

Title: Technical Lead 
WII RCRA Inspection, cont.

PROJECT NO.

3

from Page 2

BOOK NO.

ar u $333-4$-3aus Disposal unit

30 . Arrived at cru 333 and performed inspection

Photos:

1. Gate

2. Feredine looking $N$ (from gate)

3. Fenceline looking $S$ (from gate

4. Fenceline (from north looking south)

5. Fenceline (from west looking east)

6. Fenceline (from south looking north)

7. Fenceline (from east looking west)

Fencing, Signs: good condition; No issues or concerns

CAL 92 - Area 6 Decor Pond

12:00 -Arrived at site \& performed inspection

15 Photos:

1. Center $N$

5. Outside $N$

2. center $E$

6. outside $W$

3. center $S$ 7. outside $S$

4. center $W$

8. outside $E$

20 Fencing, signs: good condition

Cover: good, no vegetation was present

wave barrier: good condition

no issues or concerns

15

www.scientilicbindery88yrs.com

SIGNATURE

DISCLOSED TO AND UNDERSTOOD BY

cor

At

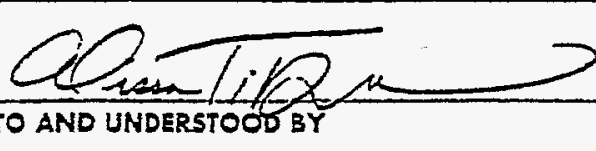

Work continued to Page 4

$$
\frac{6 / 23 / 04}{\text { DATE }}
$$




\section{CAU 92: AREA 6 DECON POND FACILITY, POST-CLOSURE INSPECTION CHECKLIST}

\begin{tabular}{||l|l|l|}
\hline \hline Inspection Date and Time: $9 / 14 / 2004,12: 05 \mathrm{pm}$ & Reason for Inspection: Quarterly \\
\hline Date of Last Post-Closure Inspection: 6/23/2004 & Reason for Last Post-Closure Inspection: Quarterly \\
\hline Responsible Agency: Bechtel Nevada Environmental Restoration & Organization: Environmental Restoration \\
\hline Address: Nevada Test Site, Mercury, Nevada & Title: Technical Lead & Organization: Environmental Restoration \\
\hline Responsible Agency Official: Jeffrey L. Smith, Project Manager & Title: Task Manager & \\
\hline Chief Inspector: Alissa Tibesar &
\end{tabular}

\section{A. GENERAL INSTRUCTIONS}

1. All checklist items must be completed and detailed comments made to document the results of the site inspection. The completed checklist is part of the field record of the inspection. Additional pages should be used as necessary to ensure that a complete record is made. Attach the additional pages and number all pages upon completion of the inspection.

2. Any checklist line item marked by an inspector in a SHADED BOX must be fully explained or an appropriate reference to previous reports provided. The purpose of this requirement is to provide a written explanation of inspector observations and the inspector's rationale for conclusions and recommendations. Explanations are to be placed on additional attachments and cross-referenced appropriately. Explanations, in addition to narrative, will take the form of sketches, measurements, and annotated site maps.

3. The site inspection is a walking inspection of the entire site including the perimeter and sufficient transects to be able to inspect the entire surface and all features specifically described in this checklist.

4. A standard set of color photographs is required. In addition, all anomalous features or new features (such as changes in adjacent area land use) are to be photographed. A photograph log entry will be made for each photograph taken.

5. Field notes taken to assist in completion of this checklist will become part of the inspection record. No form is specified for field notes; however, they must be legible and in sufficient detail to enable review by succeeding inspectors and the responsible agency.

6. This unit will be inspected quarterly with formal reporting to the Nevada Division of Environmental Protection to be done annually. The annual report will include an executive summary, this inspection checklist with field notes and photograph log attached, and recommendations and conclusions.

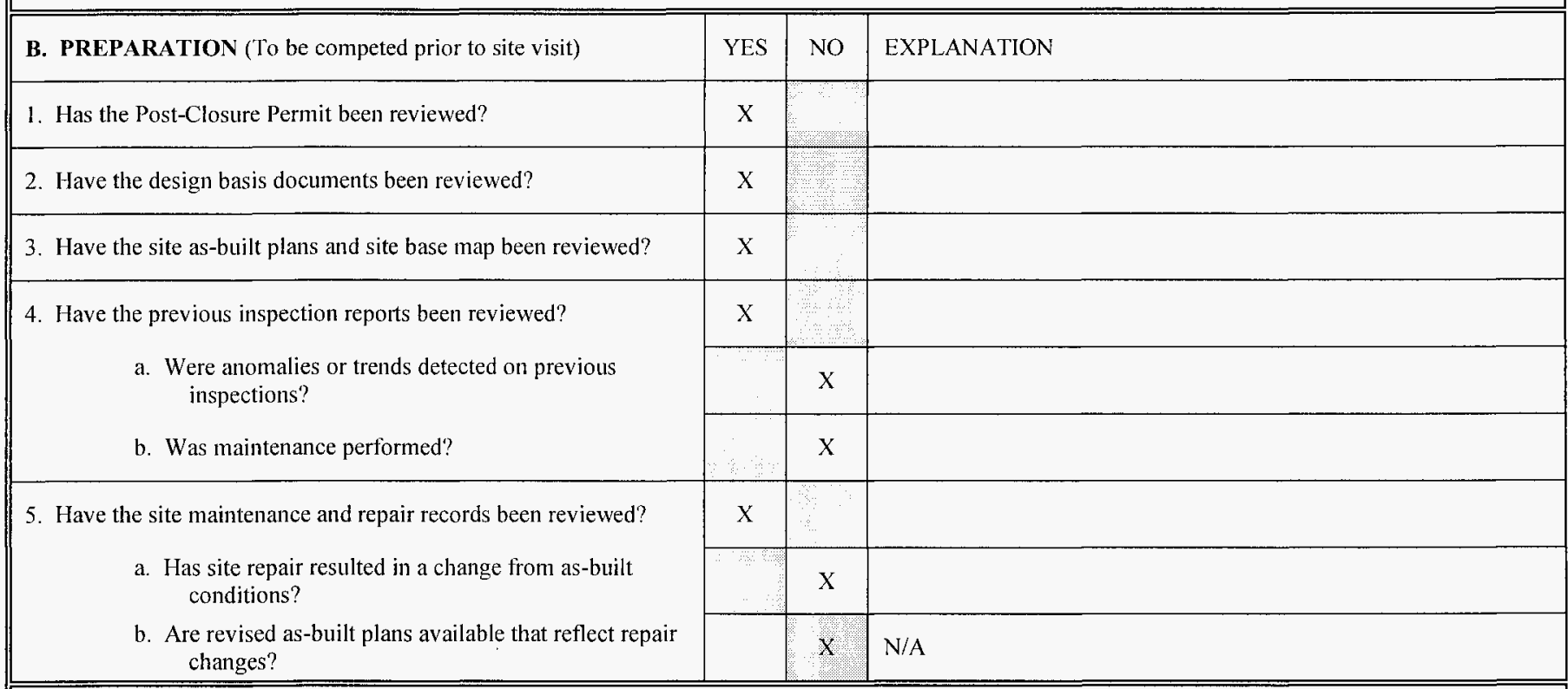

\section{SITE INSPECTION PREPARATION}

Assemble the following, as needed, to conduct inspections:

a. Camera, film, and batteries

b. Keys to locks

c. Clipboard

d. Tape measure

e. Radio, pager, etc.

f. Previous Post-Closure Report, Inspection Checklists, repair records, and as-built plans

g. Other miscellaneous support equipment 


\begin{tabular}{|c|c|c|c|}
\hline \multicolumn{4}{|c|}{ CAU 92: AREA 6 DECON POND FACILITY, POST-CLOSURE INSPECTION CHECKLIST } \\
\hline D. SITE INSPECTION & YES & NO & EXPLANATION \\
\hline \multicolumn{4}{|l|}{ 1. Adjacent off-site features: } \\
\hline \multirow{2}{*}{$\begin{array}{l}\text { a. Have there been any changes in the use of the adjacent } \\
\text { area? }\end{array}$} & & $\mathrm{X}$ & \\
\hline & & $X$ & \\
\hline \multirow{2}{*}{$\begin{array}{l}\text { b. Are there any new roads or trails? } \\
\text { c. Has there been any change in the position of nearby } \\
\text { washes? } \\
\text { d. Has there been lateral excursion or erosion/deposition of } \\
\text { nearby washes? }\end{array}$} & & $X$ & \\
\hline & & $x$ & \\
\hline e. Are there new drainage channels? & & $X$ & \\
\hline f. Has there been a change in the surrounding vegetation? & & $\mathrm{X}$ & \\
\hline \multicolumn{4}{|l|}{ 2. Access roads, fences, gates, and signs: } \\
\hline \multirow{2}{*}{$\begin{array}{l}\text { a. Is there a break in the fence? } \\
\text { b. Have any posts been damaged or their anchoring } \\
\text { weakened? }\end{array}$} & 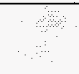 & $\mathrm{X}$ & \\
\hline & & $X$ & \\
\hline c. Does the gate show evidence of tampering or damage? & $X$ & & $\begin{array}{l}\text { The wave barrier (fiberglass slats laced through the bottom of the } \\
\text { chain-link fencing) is slightly damaged by weather. }\end{array}$ \\
\hline d. Was the gate locked? & $X$ & 今es & \\
\hline e. Is there any evidence of human intrusion onto the cover? & & $\mathrm{X}$ & \\
\hline $\begin{array}{l}\text { f. Is there any evidence of large animal intrusion onto the } \\
\text { cover? }\end{array}$ & & $X$ & \\
\hline $\begin{array}{l}\text { g. Have any signs been damaged or removed? } \\
\text { (Number of signs replaced: __ }\end{array}$ & & $X$ & \\
\hline h. Other? & & $\mathrm{X}$ & \\
\hline \multicolumn{4}{|l|}{ 3. Monuments and other permanent features: } \\
\hline \multirow{3}{*}{$\begin{array}{l}\text { a. Have survey markers, boundary monuments, or monitoring } \\
\text { stations been disturbed? } \\
\text { b. Do natural processes threaten the integrity of any survey } \\
\text { marker, boundary monument or monitoring station? } \\
\text { c. Is there excessive vegetation around the survey markers. } \\
\text { boundary monuments, or monitoring stations? }\end{array}$} & & $\mathrm{X}$ & \\
\hline & & $X$ & \\
\hline & & $\mathrm{X}$ & \\
\hline d. Other? & & $x$ & \\
\hline \multicolumn{4}{|l|}{ 4. Waste unit cover: } \\
\hline a. Is there evidence of settling? & & $x$ & \\
\hline b. Is there evidence of cracking? & $x$ & & No change in desiccation cracks since last inspection. \\
\hline c. Is there evidence of erosion (wind or water)? & $\mathrm{X}$ & & No change in rivulets since last inspection. \\
\hline d. Is there evidence of animal burrowing? & & $\mathrm{x}$ & \\
\hline e. Is there vegetation growing on the cover? & & $x$ & \\
\hline g. Other (including trash, debris, etc within fenced area)? & $\mathrm{x}$ & & A small amount of debris has accumulated in the corners of the unit. \\
\hline
\end{tabular}




\section{CAU 92: AREA 6 DECON POND FACILITY, POST-CLOSURE INSPECTION CHECKLIST}

5. Photograph Instructions:

A total of 8 photographs are required to be taken during each inspection of CAU 92. Additional photographs may also be taken. The required photographs shall be taken as follows:

- Four (4) from the center of the unit, one in each compass direction (i.e., N, S, E, W) and

- Four (4) of the unit from outside the fence, one in each compass direction.

6. Photograph Documentation:

a. Have all photographs required by the photograph instructions been taken?

b. Has a photograph log been prepared? (Number of photographs taken: $\underline{8}$ )

c. Other?

\begin{tabular}{|c|c|l|}
\hline YES & NO & EXPLANATION \\
\hline $\mathrm{X}$ & & \\
\hline $\mathrm{X}$ & & $\begin{array}{l}\text { Photos 1-4 will be re-ordered in the report to match the order } \\
\text { presented in Q1 inspection }-\mathrm{N}, \mathrm{E}, \mathrm{S}, \mathrm{W}\end{array}$ \\
\hline & $\mathrm{X}$ & \\
\hline
\end{tabular}

\section{E. FIELD CONCLUSIONS}

1. Is there an imminent hazard to the integrity of the unit? (Immediate report required)

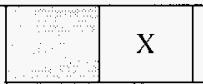

Person/Agency to whom report was made:

2. Are more frequent inspections required?

3. Are existing maintenance/repair actions satisfactory?

4. Is other maintenance/repair necessary?

\begin{tabular}{|c|c|}
\hline & $\mathrm{X}$ \\
\hline $\mathrm{x}$ & \\
$\mathrm{x}$ & \\
\hline
\end{tabular}

The wave barriers need to be repaired, and the debris should be removed.

5. Field conclusions/recommendations: No issues or concerns were noted. Repair wave barriers and remove debris as soon as practical. Continue site inspections as scheduled.

\section{F. CERTIFICATION}

I have conduction an inspection of CAU 92, Area 6 Decon Pond Facility, in accordance with the procedures of the Post-Closure Permit (including the PostClosure Plan) as recorded on this checklist, attached sheets, field notes, photographs, and photograph logs.

Chief Inspector's Signature:

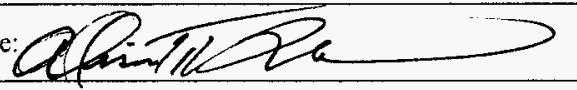

Printed Name: Alissa Tibesar

Date: $9 / 14 / 2004$

Title: Technical Lead 
TITLE RLRA Inspections

Work continued from Page 10
PROJECT NO.

BOOK NO.

- Both areas of subsidence continue to be at actionable levels. Soil around edges is tunneling, and animal burrows are prevalent in these areas.

FleE Ant hills and animal burrows were noted on cover

- No other issues or concerns noted.

- Recommend repairing subsidence and killing fire ants.

$11: 24$ an - Sighed out of Area 3 Rums

11:40 am -arrived at U-3fi

10

CAU 91-A3 U-3fi Injection well

Photos:

1. Center looking $N$

7. Animal burrow

2. Center looking $E$

8. 11

15

3. Center looking

9. outside looking N

4. Center looking W 10. outside looking E

5. Wellhead looking $N$ il outside looking $S$

6. Wellhead looking 5 outside looking. W

- Small animal burrows backfilled during inspection.

20

- No issues or concerns.

12:05 pm -arrived at Decor Pond

CAn 92 - A6 Decor Pond Facility

Photos: 1.0 uts eide looking

25

3. outside looking 5 6. center looking

5. center tooting $N$

4 outside looking $\mathrm{N}$

8. center looking 5

(last \& take we disposable $35 \mathrm{~nm}$ camera)

- Animal barricades on fence need repair:

- Dead brush in corners

wwuscientificbinderys8yrs.om no other issues or concerns Work continued to Page -

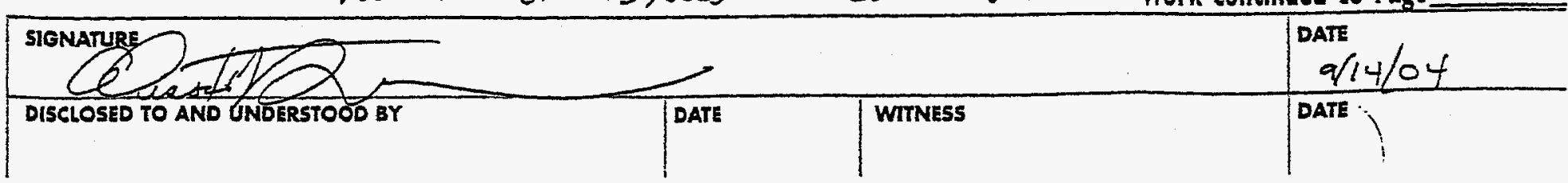




\section{CAU 92: AREA 6 DECON POND FACILITY, POST-CLOSURE INSPECTION CHECKLIST}

\begin{tabular}{|l|l|}
\hline \hline Inspection Date and Time: $12 / 14 / 04 \quad 1125$ & Reason for Inspection: Quarterly \\
\hline Date of Last Post-Closure Inspection: $9 / 14 / 04$ & Reason for Last Post-Closure Inspection: Quarterly \\
\hline
\end{tabular}

Responsible Agency: Bechtel Nevada Environmental Restoration

Address: Nevada Test Site, Mercury, Nevada

Responsible Agency Official: Jeffrey L. Smith, Project Manager

\begin{tabular}{|l|l|l} 
Chief Inspector: ALISSA TBESAR & Title: TECHICAL LEAD & Organization: Environmental Restoration \\
\hline Assistant Inspector:SHAUGH BURMISon & Title: TASK MANAEER & Organization: Environmental Restoration \\
\hline
\end{tabular}

\section{A. GENERAL INSTRUCTIONS}

1. All checklist items must be completed and detailed comments made to document the results of the site inspection. The completed checklist is part of the field record of the inspection. Additional pages should be used as necessary to ensure that a complete record is made. Attach the additional pages and number all pages upon completion of the inspection.

2. Any checklist line item marked by an inspector in a SHADED BOX must be fully explained or an appropriate reference to previous reports provided. The purpose of this requirement is to provide a written explanation of inspector observations and the inspector's rationale for conclusions and recommendations. Explanations are to be placed on additional attachments and cross-referenced appropriately. Explanations, in addition to narrative, will take the form of sketches, measurements, and annotated site maps.

3. The site inspection is a walking inspection of the entire site including the perimeter and sufficient transects to be able to inspect the entire surface and all features specifically described in this checklist.

4. A standard set of color photographs is required. In addition, all anomalous features or new features (such as changes in adjacent area land use) are to be photographed. A photograph log entry will be made for each photograph taken.

5. Field notes taken to assist in completion of this checklist will become part of the inspection record. No form is specified for field notes; however, they must be legible and in sufficient detail to enable review by succeeding inspectors and the responsible agency.

6. This unit will be inspected quarterly with formal reporting to the Nevada Division of Environmental Protection to be done annually. The annual report will include an executive summary, this inspection checklist with field notes and photograph log attached, and recommendations and conclusions.

\begin{tabular}{|c|c|c|c|}
\hline B. PREPARATION (To be competed prior to site visit) & YES & NO & EXPLANATION \\
\hline \multicolumn{4}{|l|}{ 1. Has the Post-Closure Permit been reviewed? } \\
\hline \multicolumn{4}{|l|}{ 2. Have the design basis documents been reviewed? } \\
\hline \multicolumn{4}{|l|}{ 3. Have the site as-built plans and site base map been reviewed? } \\
\hline \multicolumn{4}{|l|}{ 4. Have the previous inspection reports been reviewed? } \\
\hline \multirow[t]{2}{*}{$\begin{array}{l}\text { a. Were anomalies or trends detected on previous } \\
\text { inspections? }\end{array}$} & & & $\begin{array}{l}\text { Wave barrier was demaged and } \\
\text { portions of fence on NW side had loose }\end{array}$ \\
\hline & & & $\begin{array}{l}\text { Wave barrier was repaired. Fence } \\
\text { repairs are pending. }\end{array}$ \\
\hline \multicolumn{4}{|l|}{ 5. Have the site maintenance and repair records been reviewed? } \\
\hline $\begin{array}{l}\text { a. Has site repair resulted in a change from as-built } \\
\text { conditions? }\end{array}$ & & & \\
\hline $\begin{array}{l}\text { b. Are revised as-built plans available that reflect repair } \\
\text { changes? }\end{array}$ & & & $N / A$ \\
\hline
\end{tabular}

\section{SITE INSPECTION PREPARATION}

Assemble the following, as needed, to conduct inspections

a. Camera, film, and batteries

b. Keys to locks

c. Clipboard

d. Tape measure

e. Radio, pager, etc.

f. Previous Post-Closure Report, Inspection Checklists, repair records, and as-built plans

g. Other miscellaneous support equipment 


\section{CAU 92: AREA 6 DECON POND FACILITY, POST-CLOSURE INSPECTION CHECKLIST}

\begin{tabular}{|l|l|l|l|}
\hline D. SITE INSPECTION & YES & NO & EXPLANATION \\
\hline
\end{tabular}

1. Adjacent off-site features:

a. Have there been any changes in the use of the adjacent area?

b. Are there any new roads or trails?

c. Has there been any change in the position of nearby washes?

d. Has there been lateral excursion or erosion/deposition of nearby washes?

e. Are there new drainage channels?

f. Has there been a change in the surrounding vegetation?

2. Access roads, fences, gates, and signs:

a. Is there a break in the fence?

b. Have any posts been damaged or their anchoring weakened?

c. Does the gate show evidence of tampering or damage?

d. Was the gate locked?

e. Is there any evidence of human intrusion onto the cover?

f. Is there any evidence of large animal intrusion onto the cover?

g. Have any signs been damaged or removed? Number of signs replaced:

h. Other?

\begin{tabular}{|l|l|l|}
\hline & $\checkmark$ & \\
\hline & $\checkmark$ & \\
\hline & $\checkmark$ & \\
\hline & $\checkmark$ & \\
\hline & $\checkmark$ & \\
\hline & $\checkmark$ & \\
\hline & $\checkmark$ & \\
\hline
\end{tabular}

\begin{tabular}{|l|l|l||}
\hline \multicolumn{1}{r|}{} & & $\begin{array}{l}\text { Eence on NW side still needs } \\
\text { repain }\end{array}$ \\
\hline & $\sim$ & \\
\hline & $\checkmark$ & \\
\hline & & \\
\hline & & \\
\hline
\end{tabular}

3. Monuments and other permanent features

a. Have survey markers, boundary montuments, or monitoring stations been disturbed?

b. Do natural processes threaten the integrity of any survey marker, boundary monument or monitoring station?

c. Is there excessive vegetation around the survey markers, boundary monuments, or monitoring stations?

d. Other?

4. Waste unit cover:
a. Is there evidence of settling?
b. Is there evidence of cracking?
c. Is there evidence of erosion (wind or water)?
d. Is there evidence of animal burrowing?
e. Is there vegetation growing on the cover?
g. Other (including trash, debris, etc within fenced area)?

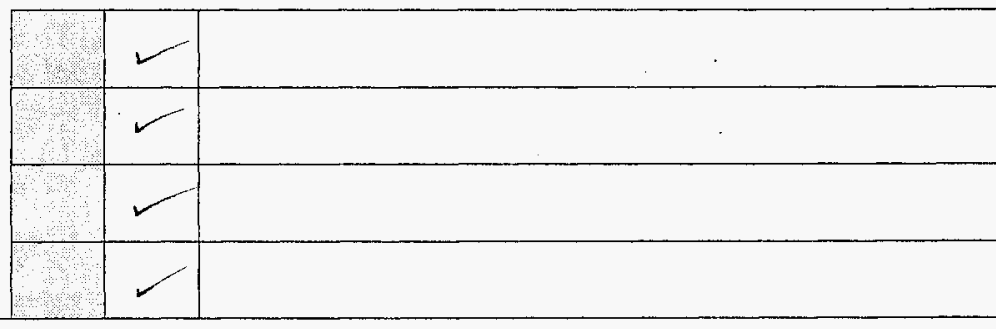

\begin{tabular}{|l|l|l||}
\hline & $\checkmark$ & \\
\hline & $\checkmark$ & \\
\hline & $\checkmark$ & \\
\hline & $\sim$ & \\
\hline & $\checkmark$ & \\
\hline
\end{tabular}




\section{CAU 92: AREA 6 DECON POND FACILITY, POST-CLOSURE INSPECTION CHECKLIST}

5. Photograph Instructions:

A total of 8 photographs are required to be taken during each inspection of CAU 92. Additional photographs may also be taken. The required photographs shall be taken as follows:

- Four (4) from the center of the unit, one in each compass direction (i.e., N, S, E, W) and

- Four (4) of the unit from outside the fence, one in each compass direction.

6. Photograph Documentation:

a. Have all photographs required by the photograph instructions been taken?

b. Has a photograph log been prepared?

(Number of photographs taken: 8 )

c. Other?

\begin{tabular}{|c|c|l|}
\hline YES & NO & EXPLANATION \\
\hline & & \\
\hline & & \\
\hline & & \\
\hline
\end{tabular}

\section{E. FIELD CONCLUSIONS}

1. Is there an imminent hazard to the integrity of the unit? (Immediate report required)

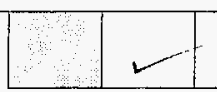

Person/Agency to whom report was made:

2. Are more frequent inspections required?

3. Are existing maintenance/repair actions satisfactory?

4. Is other maintenance/repair necessary?

5. Field conclusions/recommendations: The unit is in excelleut condition. The fence that has loosened from the posts on the NW side still need to be repared.

\section{F. CERTIFICATION}

I have conduction an inspection of CAU 92, Area 6 Decon Pond Facility, in accordance with the procedures of the Post-Closure Pernit (including the PostClosure Plan) as recorded on this checklist, attached sheets, field notes, photographs, and photograph logs.

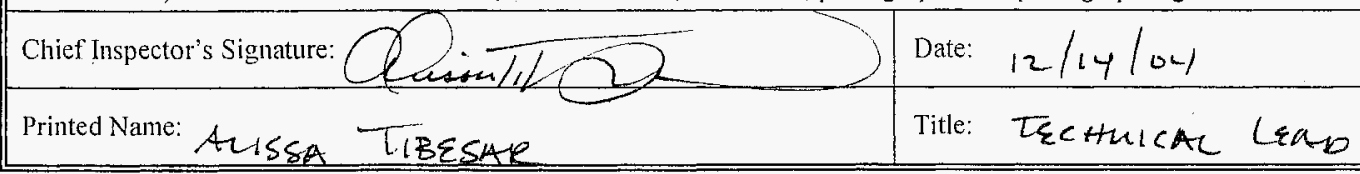


TITLE RCRA inspections

Work continued from Page 42
PROJECT NO.

BOOK NO.

43

- Minor animal burrows were backfilled by foot during inspection.

- Signs and fencing are in excellent condition.

- cover and concrete pads are in excellent condition.

1125 - Arrived at cal 92 in Area 6

5

Photos: Outside: (1) North

(2) east

(3) South (4) west

Center: (5) North (6) east

(7) South

(8) west

- walked site. wave barriers have bun repaired. Fence repairs are still pending due to recent rain. No vegetation is present on the cover. The monuments may need sulfaset, because 10 it is cracking around the brass markers. Signs are in excellent condition

1215-Arrived at CAU 112 in Area 23

- Drove site. Sighs are thin and worn and still need to be replaced. Fence is in good condition. Monuments and riprap appears to be in good condition. Miner vegetation is growing on the cover.

1230 -Headed back to office.

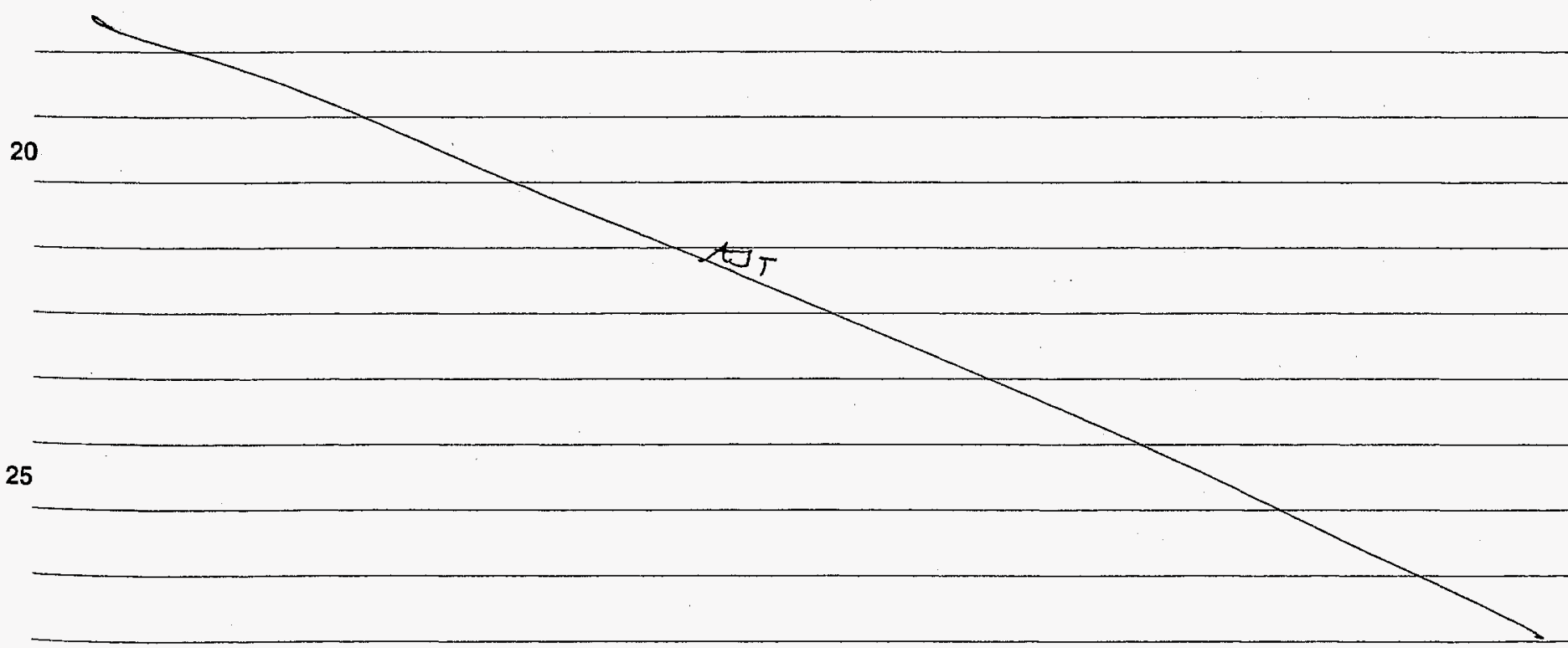

www.scientificbindery88yrs.com 


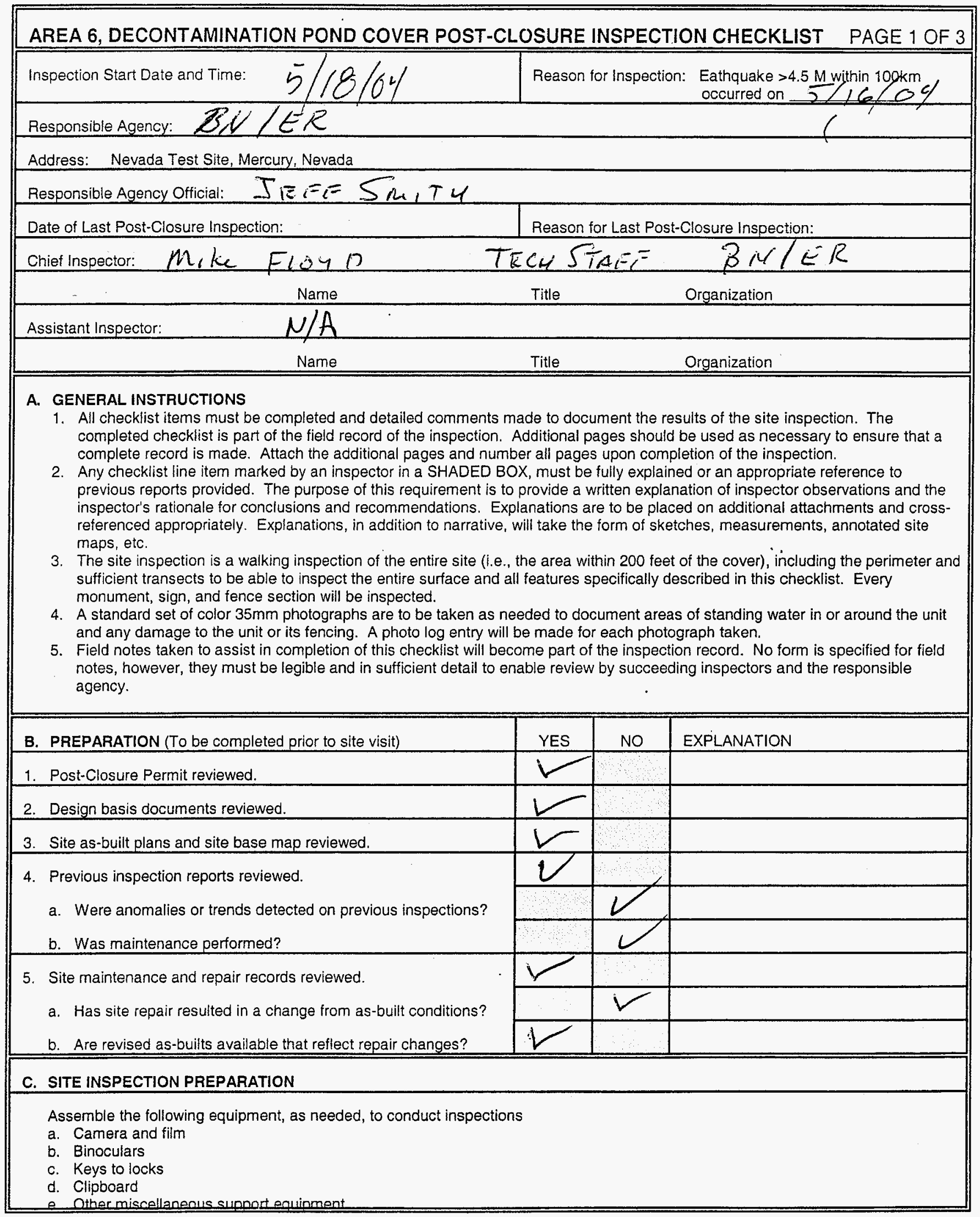




\begin{tabular}{|c|c|c|c|}
\hline $\begin{array}{l}\text { AREA } 6 \text { DECON POND POST-CLOSURE INSPECTION CHECKLIST } \\
\text { (cont.) }\end{array}$ & YES & NO & EXPLANATION PAGE 2 OF 3 \\
\hline \multicolumn{4}{|l|}{ D. SITE INSPECTION (To be completed during inspection) } \\
\hline \multicolumn{4}{|l|}{$\begin{array}{l}\text { 1. Adjacent off-site features of Area } 6 \text { Decontamination Pond Cover. } \\
\text { a. Have there been any changes in use of adjacent area? }\end{array}$} \\
\hline \multirow{2}{*}{$\begin{array}{l}\text { b. Are there any new roads or trails? } \\
\text { c. Other? }\end{array}$} & & & \\
\hline & & & \\
\hline \\
\hline \multicolumn{4}{|l|}{ a. Is there a break in the fence? } \\
\hline \multicolumn{4}{|l|}{ b. Have any posts been damaged or their anchoring weakened? } \\
\hline \multicolumn{4}{|l|}{ c. Is there evidence of erosion or digging beneath the fence? } \\
\hline \multicolumn{4}{|l|}{ d. Does the gate show evidence of tampering or damage? } \\
\hline \multicolumn{4}{|l|}{ e. Is there any evidence of human intrusion? } \\
\hline \multicolumn{4}{|l|}{ f. Is there any evidence of animal intrusion/burrowing? } \\
\hline \multicolumn{4}{|l|}{$\begin{array}{l}\text { g. Have any signs been damaged or femoved? } \\
\text { (Number of signs replaced: }\end{array}$} \\
\hline \multicolumn{4}{|l|}{ I. Other? } \\
\hline \multicolumn{4}{|l|}{ 3. Monuments and other permanent features } \\
\hline \multicolumn{4}{|l|}{$\begin{array}{l}\text { a. Have the survey or boundary monuments been defaced or } \\
\text { disturbed? }\end{array}$} \\
\hline \multicolumn{4}{|l|}{$\begin{array}{l}\text { b. Have the site markers been disturbed by man or natural } \\
\text { processes? }\end{array}$} \\
\hline \multicolumn{4}{|l|}{$\begin{array}{l}\text { c. Do natural processes threaten the integrity of any monument } \\
\text { or site marker? }\end{array}$} \\
\hline \multicolumn{4}{|l|}{ d. Other? } \\
\hline \multicolumn{4}{|l|}{ 4. Area 6 Decontamination Pond RCRA Cover } \\
\hline \multicolumn{4}{|l|}{ a. Is there evidence of settling? } \\
\hline \multicolumn{4}{|l|}{ b. Is there cracking? } \\
\hline \multicolumn{4}{|l|}{ c. Is there evidence of erosion on the cover (wind or water)? } \\
\hline \multicolumn{4}{|l|}{ d. Is there evidence of animal burrowing? } \\
\hline \multicolumn{4}{|l|}{ e. Is there vegetation growing on the cover? } \\
\hline \multicolumn{4}{|l|}{ f. Is there standing water on the cover? } \\
\hline g. Other (including trash, debris, etc. within fenced area)? & & & \\
\hline
\end{tabular}




\begin{tabular}{|l|l|l|l|}
\hline $\begin{array}{l}\text { AREA } 6 \text { DECON POND POST-CLOSURE INSPECTION CHECKLIST } \\
\text { (cont.) }\end{array}$ & YES & NO & EXPLANATION \\
\hline
\end{tabular}

5. Photo Instructions

Photograph(s) are to be taken as needed to document areas of standing water in or around unit and any damage to the unit or its fencing. A photo log will be prepared for each photo taken.

6. Photo Documentation
a. Have photos been taken?
b. Has a photo log been prepared for each picture taken?
c. Number of pictures taken: (\$ photos taken)
d. Other?

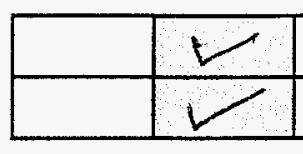

\section{E. FIELD CONCLUSIONS}

1. Is there an imminent hazard to the integrity of the Area 6 Decontamination Pond Cover? (Immediate report required)

Person/Agency to whom report made:

\begin{tabular}{|l|l|l|}
\hline 2. Are more frequent inspections required? & \\
\hline 3. Are existing maintenance/repair actions satisfactory? & & \\
\hline 4. Is other maintenance/repair necessary? & & \\
\hline
\end{tabular}

5. Field conclusions/recommendations: Site found to be in good condution, no issues as concerns

\section{F. CERTIFICATION}

I have conducted an inspection of the Area 6 Decontamination Pond Cover at the NTS in accordance with the procedures of the PostClosure Permit (including the Post-Closure Plan) as recorded on this checklist, attached sheets, field notes, photo logs, and photographs.

Chief Inspector's Signature




$$
\begin{aligned}
& \text { TITLE } \\
& \text { Work continued from Page__ MSE FRAINING }
\end{aligned}
$$

103

$5 / 18 / 04$ A.6 Decom Pand EnRtheuake zaspecrom

A-6 Decon Pond Cau 92 was Fouded to

-Be in qood Condhtion ard ouly Recomal scueduled Insiecteus THE InTEGRTY of THK CAPleover is mithed unchong od.

Dever wlkerbiside if working - No vegization 10 On CAP/COVER.
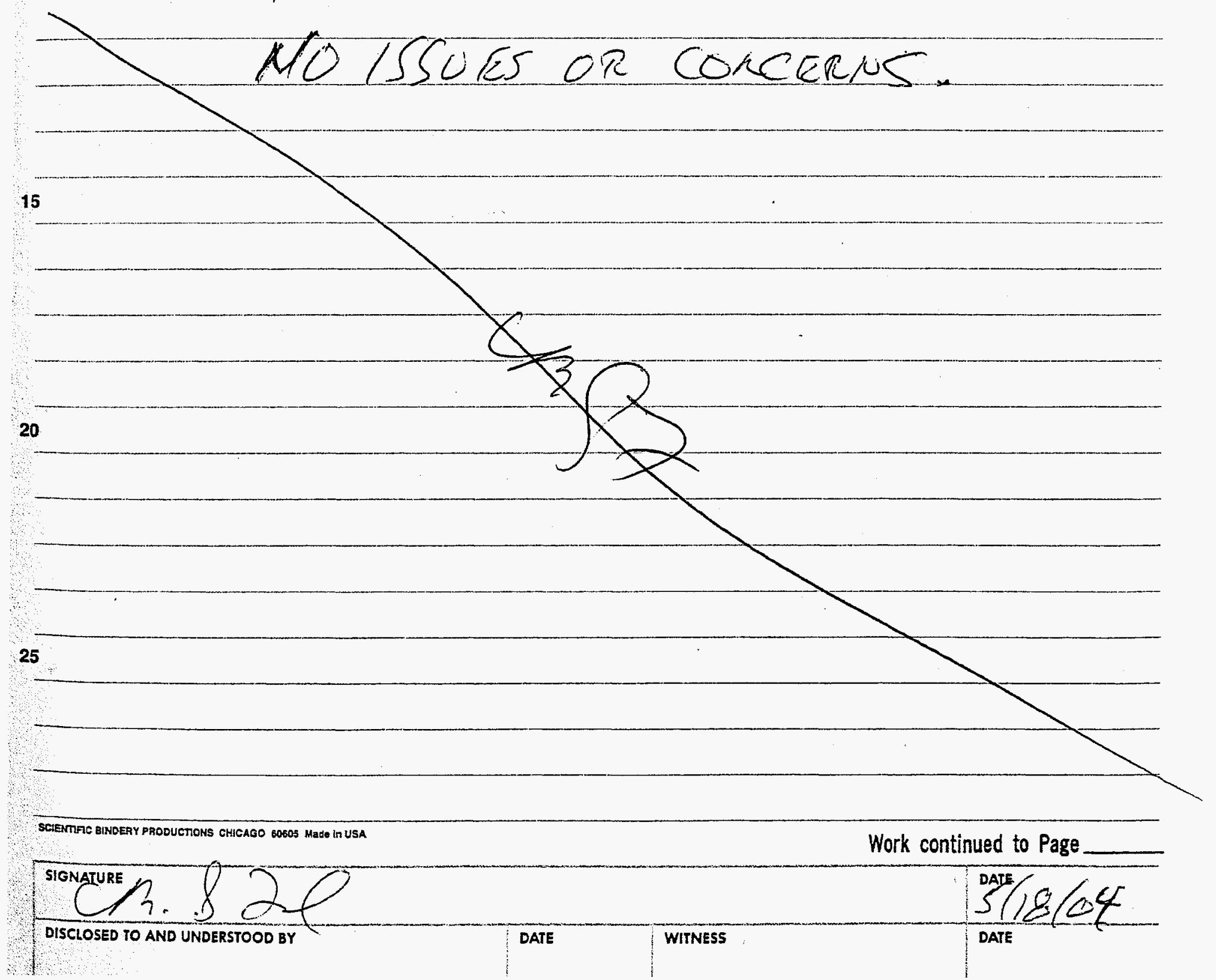


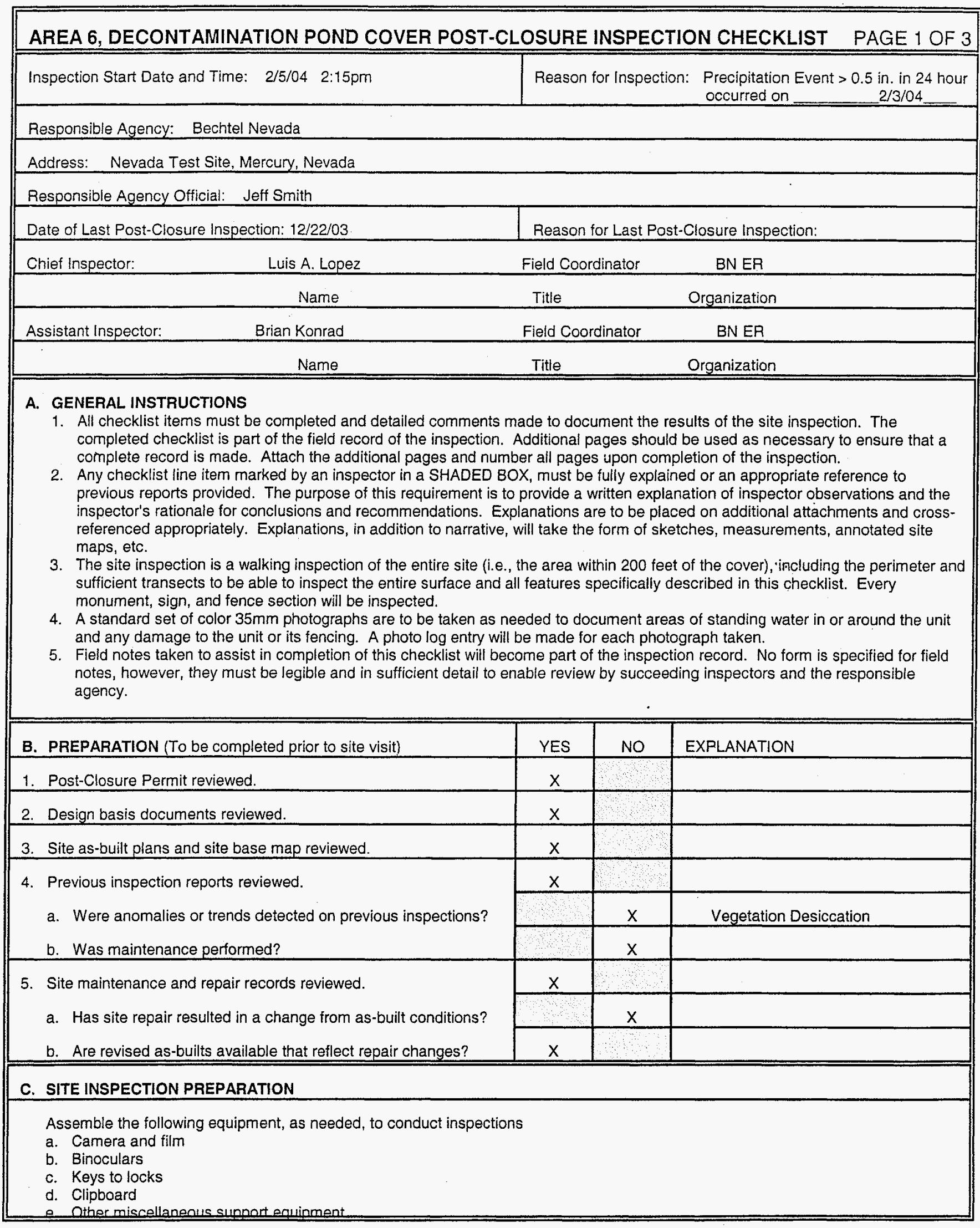




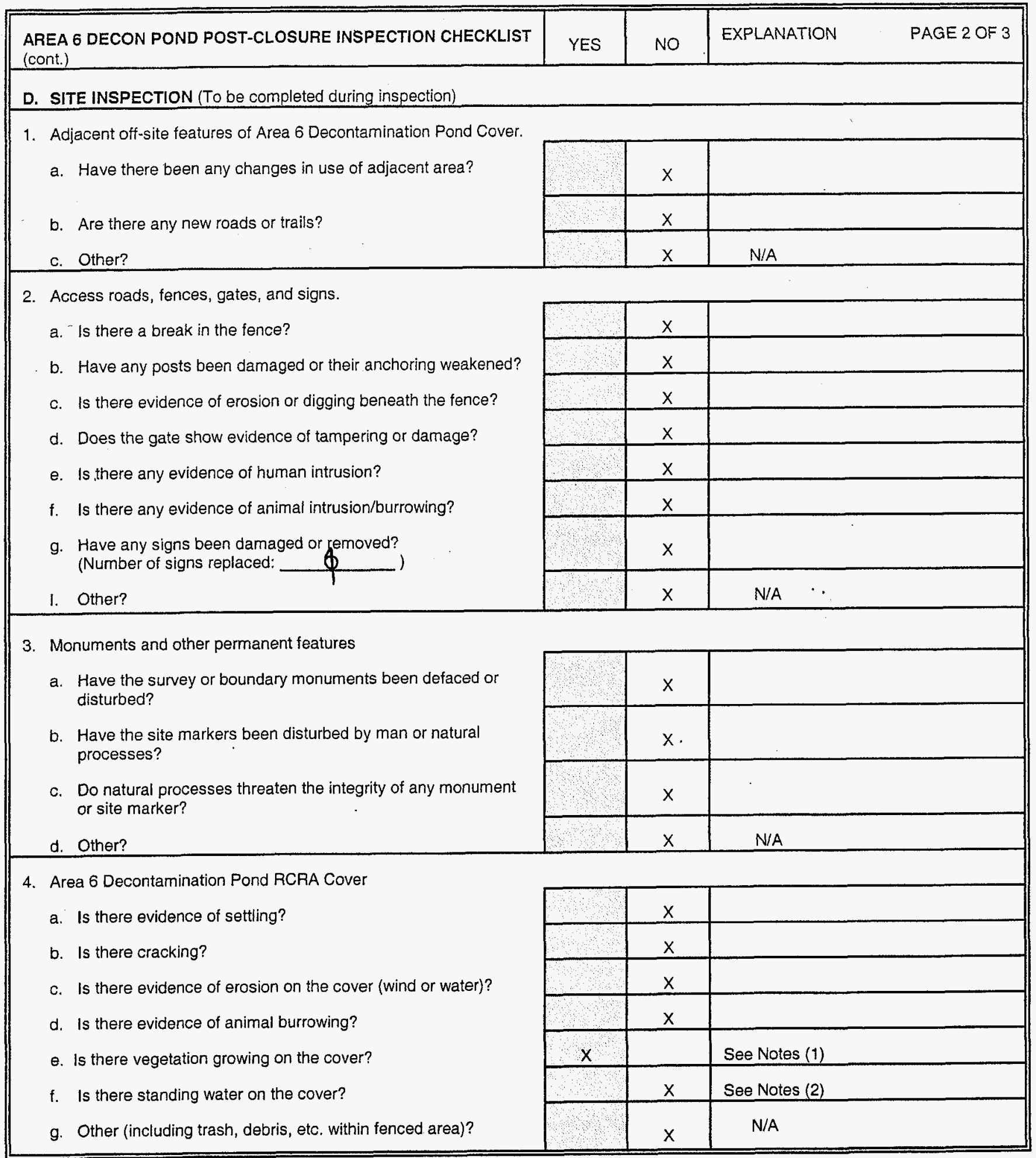




\begin{tabular}{|l|l|l|l|}
\hline $\begin{array}{l}\text { AREA } 6 \text { DECON POND POST-CLOSURE INSPECTION CHECKLIST } \\
\text { (cont.) }\end{array}$ & YES & NO & EXPLANATION \\
\hline
\end{tabular}

5. Photo Instructions

Photograph(s) are to be taken as needed to document areas of standing water in or around unit and any damage to the unit or its fencing. A photo log will be prepared for each photo taken.

6. Photo Documentation

a. Have photos been taken?

b. Has a photo log been prepared for each picture taken?

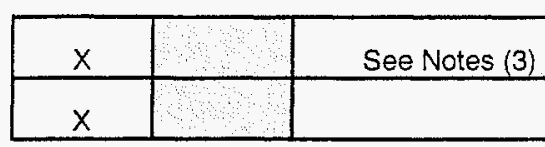

c. Number of pictures taken: $\quad 3$ photos taken)

d. Other?

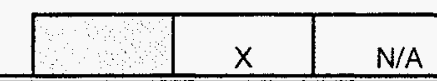

\section{E. FIELD CONCLUSIONS}

1. Is there an imminent hazard to the integrity of the Area 6 Decontamination Pond Cover? (Immediate report required)

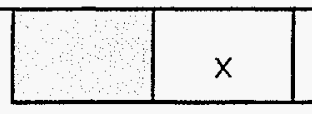

Person/Agency to whom report made:

2. Are more frequent inspections required?

3. Are existing maintenance/repair actions satisfactory?

4. Is other maintenance/repair necessary?

See Notes (4)

5. Field conclusions/recommendations:

Notes:

(1) Vegetation has grown on cover, however it is dormant and dried.

(2) No standing water was noted on the cover. However, standing water was noted along the perimeter of fence.

(3) Photo \#1-From Southwest corner (gate); Photo \#2-From Sotheast corner; Photo \#3-From Northeast corner.

(4) Herbicice will be applied prior to next quarterly inspection.

\section{F. CERTIFICATION}

I have conducted an inspection of the Area 6 Decontamination Pond Cover at the NTS in accordance with the procedures of the PostClosure Permit (including the Post-Clggure Plan) as recorded on this checklist, attached sheets, field notes, photo logs, and photographs.

\begin{tabular}{|l|l|l|}
\hline Chief Inspector's Signature & Pate 2/5/04 \\
\hline
\end{tabular}


PROJECT NO. CAY $q 2$

21

TITLE

Work continued from Page N/A
BOOK NO. Nit

Thuristany 2/5/04

Coth 92: Decontamination Pond Facility CAS 06-05-02: Decutamination Pond

Ana 6 , wis

BN Members: Luis Lopez (FC), Brian Hon rad (FC), Andrew Lacey (FOM)

10 BN Visitor 3! NOWE

MLSA/NDEP VIGIlS: NONE

Equipment: one vehicle

15 Weather: $35^{\circ} \mathrm{F}$, winds $10-15 \mathrm{mph}$, mostly sunny

Scope: Person precipitation triggered inspection Q CAM 92 $1: 45$ m - Left Hg or can 92

20

Tailgate surety Topics: Slipsttring/Fars, cord stress, Ecelsuow, signs / porto / Fane

2:15.Amived @ CAM 92

- Commenced site cualkdowo

- Did not notice any pounding water; everything seems good.

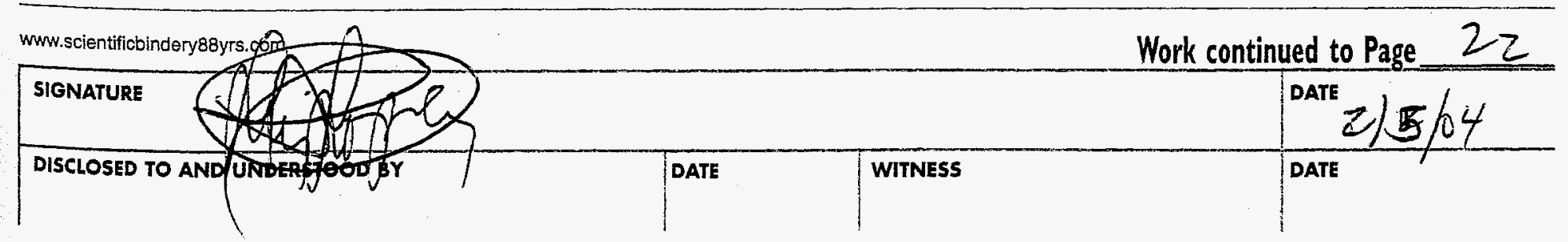


22 PROJECT NO. CAM 92 BOOK NO.

TITLE

Work continued from Page 21

- photographs taken in the following Directions.

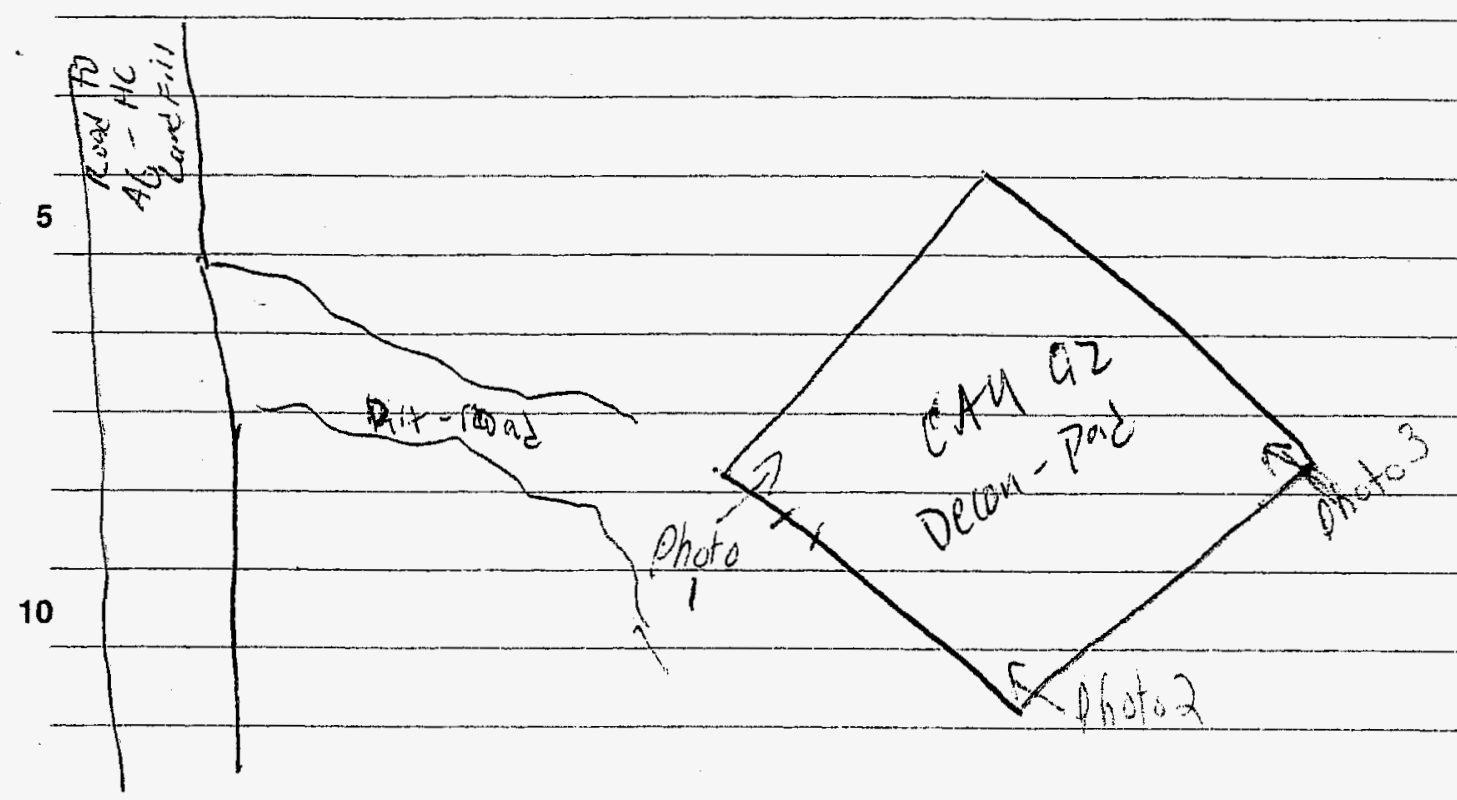

2:27 - Finisher rain tumpecrion

- Lev x lo l coxa cos and then headed yak do Hz 15

4:30- Arrive o $\mathrm{Hg}$.

20

25

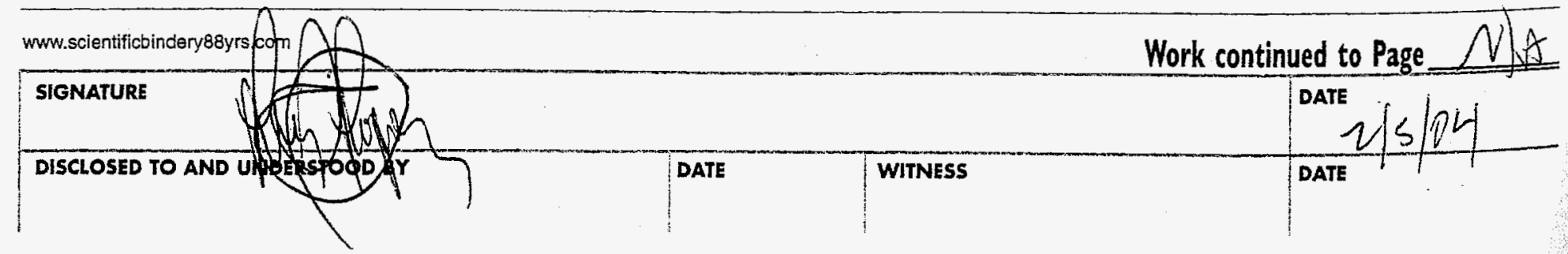





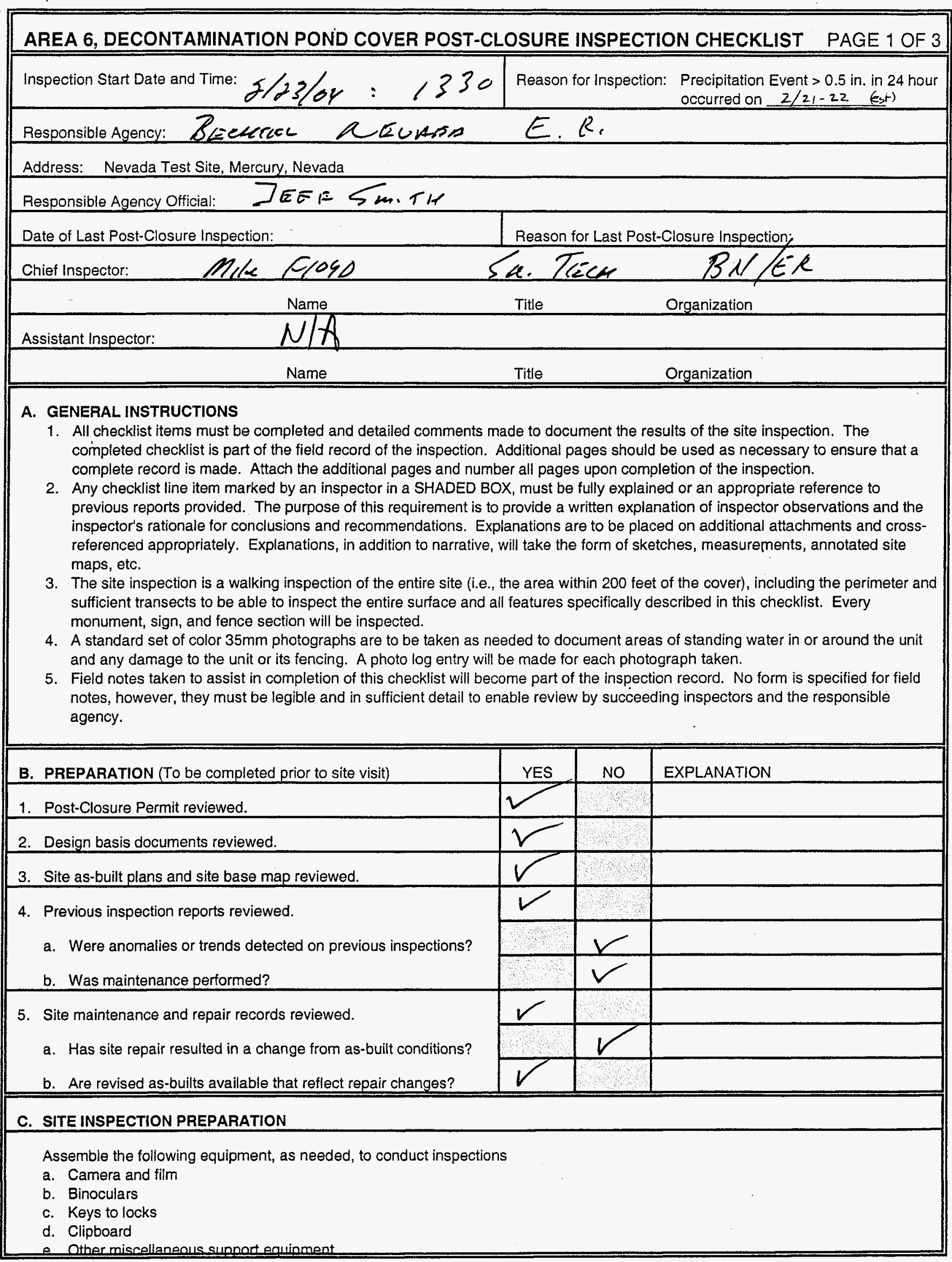




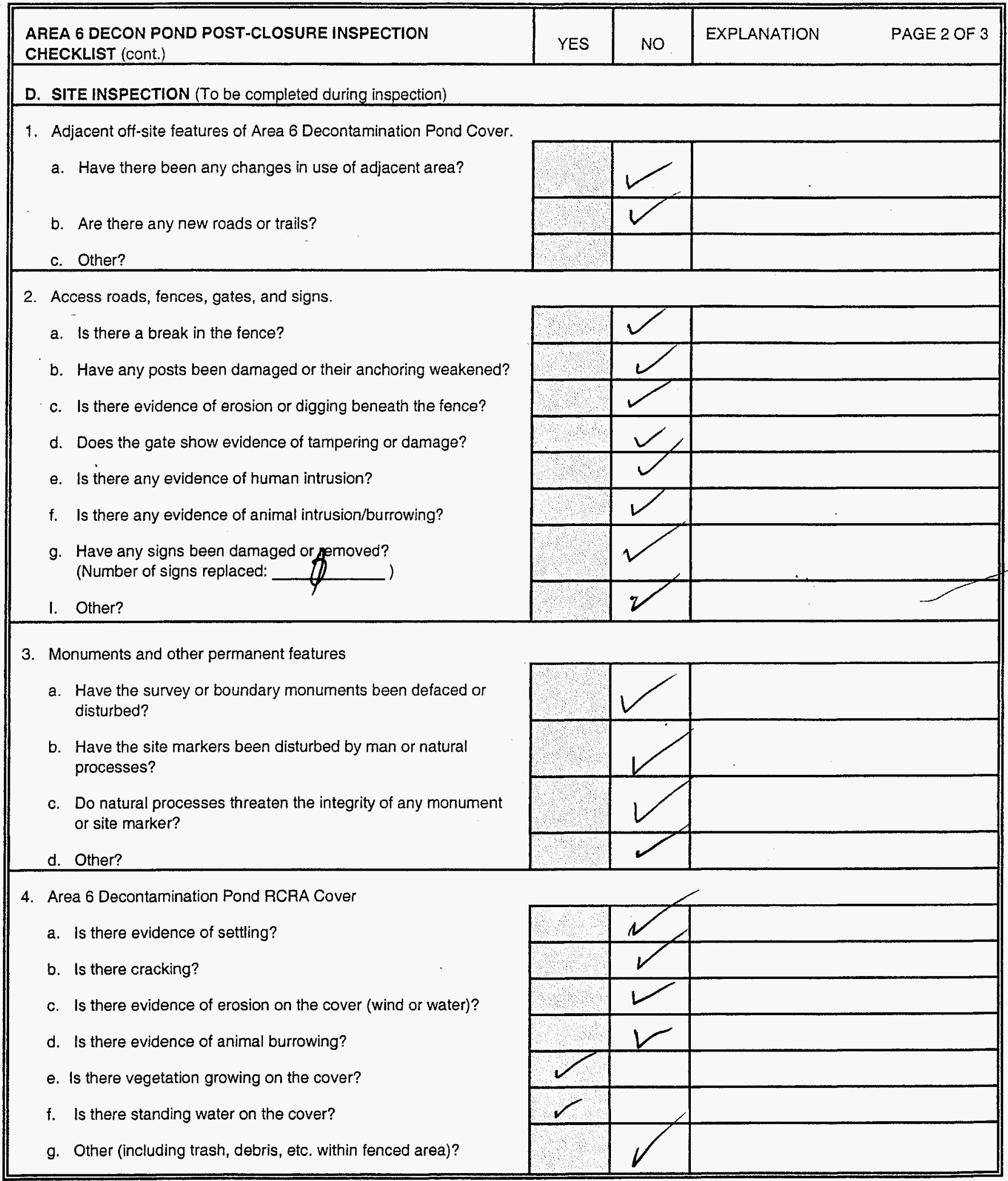




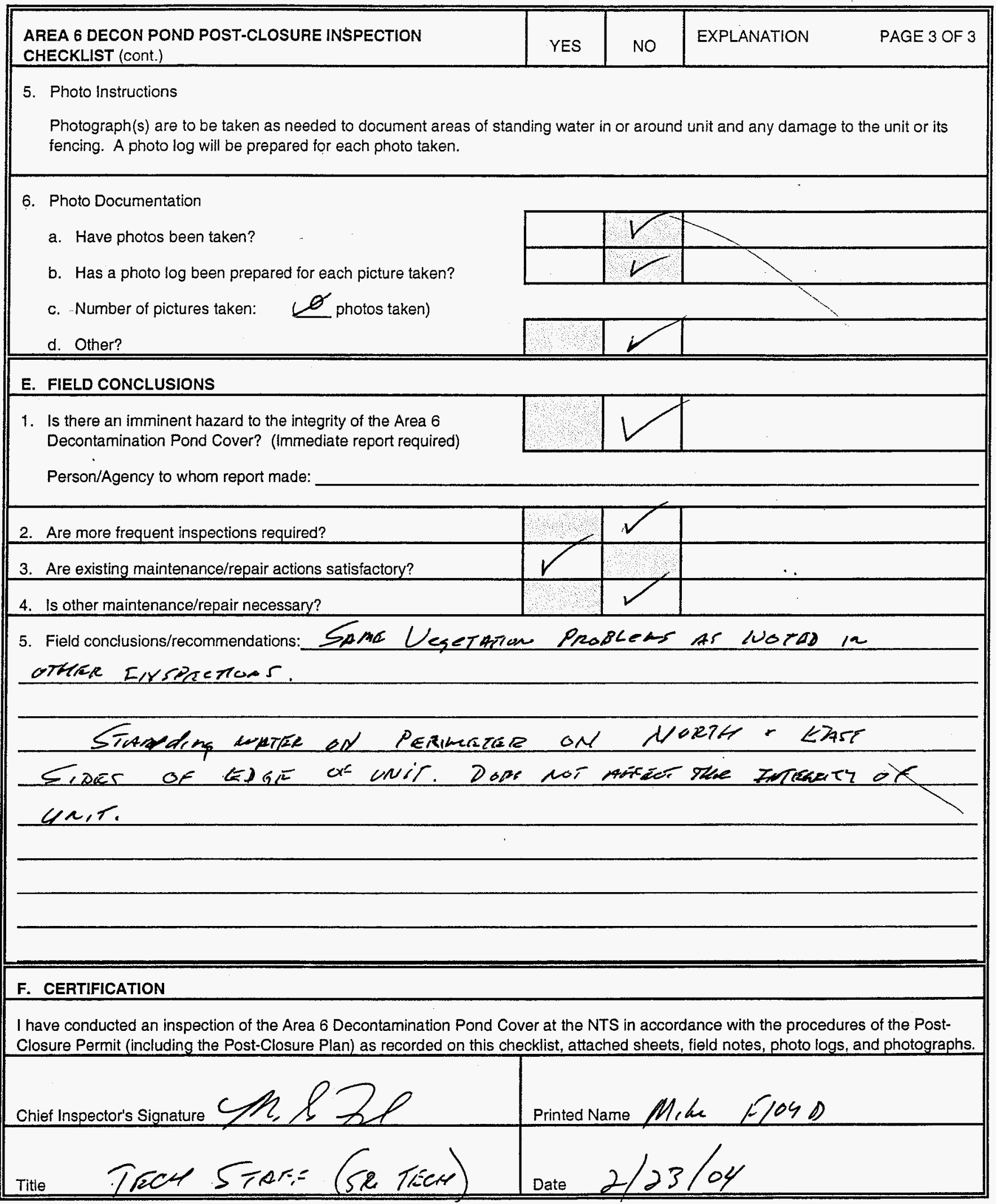


90 TITLE

Work continued from Page

PROJECT NO.

BOOK NO.

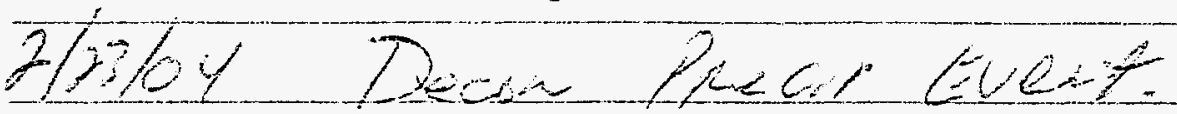

CAP Q?

5 AG Deer to ind

1. Vequerw as hared w the Jusperom Mores

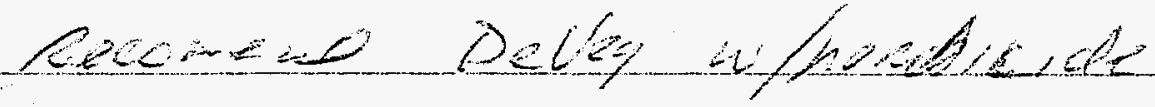

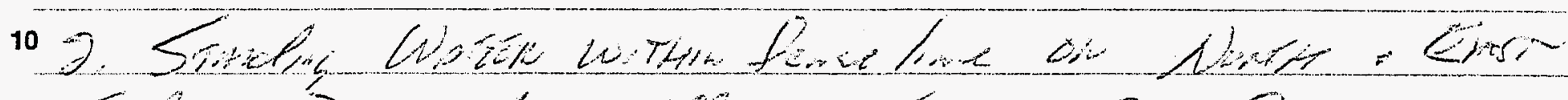
Filler, Dear Ret affect Integers of un et

15

20

25

SCIENTIFiC BINDERY PRODUCTONS CHICAGO 60005 Made in USA

Work continued to Page

SIGNATURE

$$
\sum_{\text {Date }}^{\text {DATE } j / 0 j}
$$

DISCLOSED TO AND UNDERSTOOD BY

DATE

WITNESS 


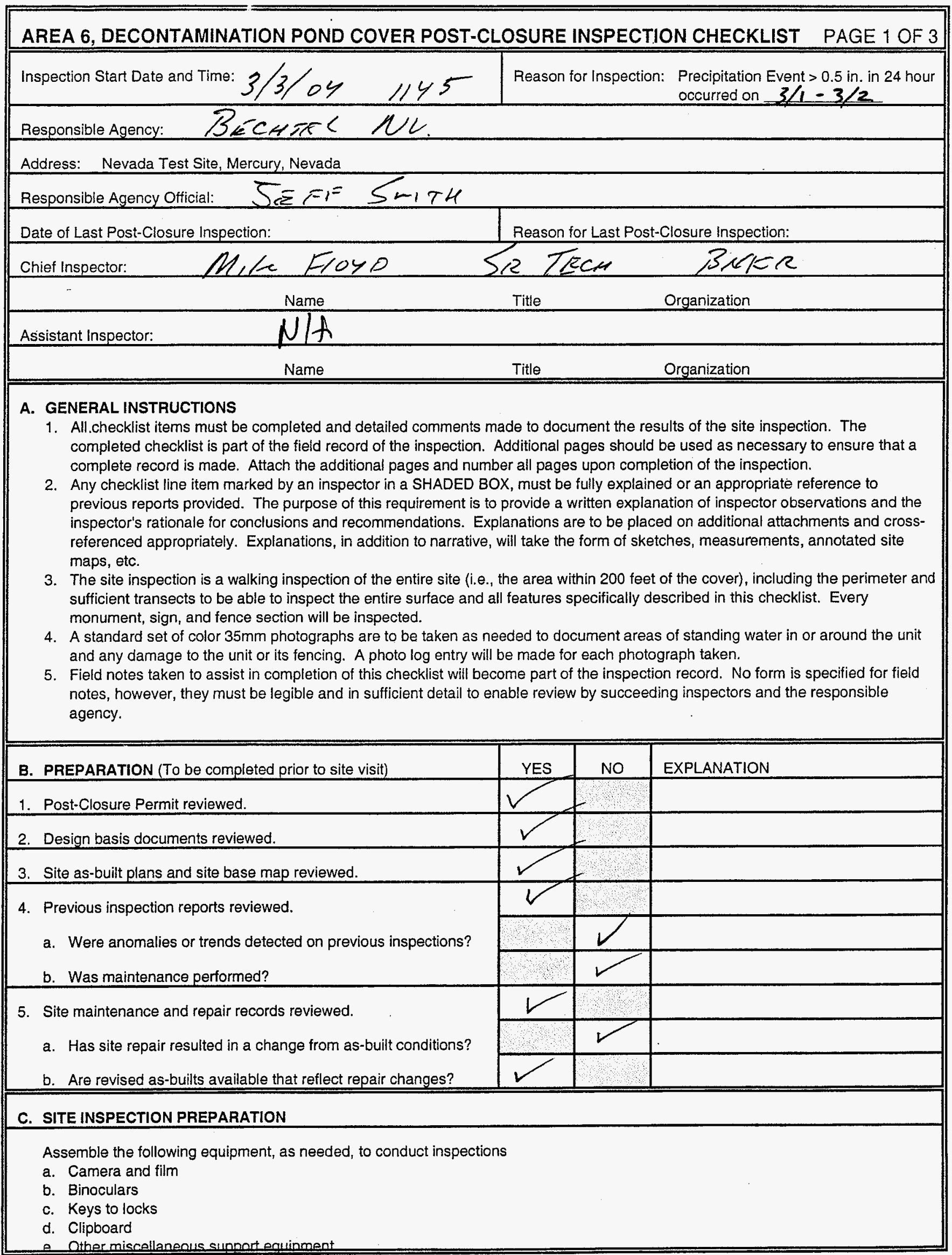




\begin{tabular}{|l|l|l|l|l|}
\hline $\begin{array}{l}\text { AREA G DECON POND POST-CLOSURE INSPECTION } \\
\text { CHECKLIST (CONT.) }\end{array}$ & YES & NO & EXPLANATION PAGE 2 OF 3 \\
\hline
\end{tabular}

D. SITE INSPECTION (To be completed during inspection)

1. Adjacent off-site features of Area 6 Decontamination Pond Cover.

a. Have there been any changes in use of adjacent area?

b. Are there any new roads or trails?

c. Other?

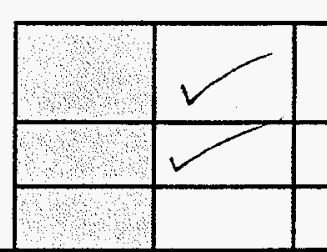

2. Access roads, fences, gates, and signs.

a. Is there a break in the fence?

b. Have any posts been damaged or their anchoring weakened?

c. Is there evidence of erosion or digging beneath the fence?

d. Does the gate show evidence of tampering or damage?

e. Is there any evidence of human intrusion?

f. Is there any evidence of animal intrusion/burrowing?

g. Have any signs been damaged orgemoved? (Number of signs replaced: $\phi^{\text {emoved? }}$

I. Other?

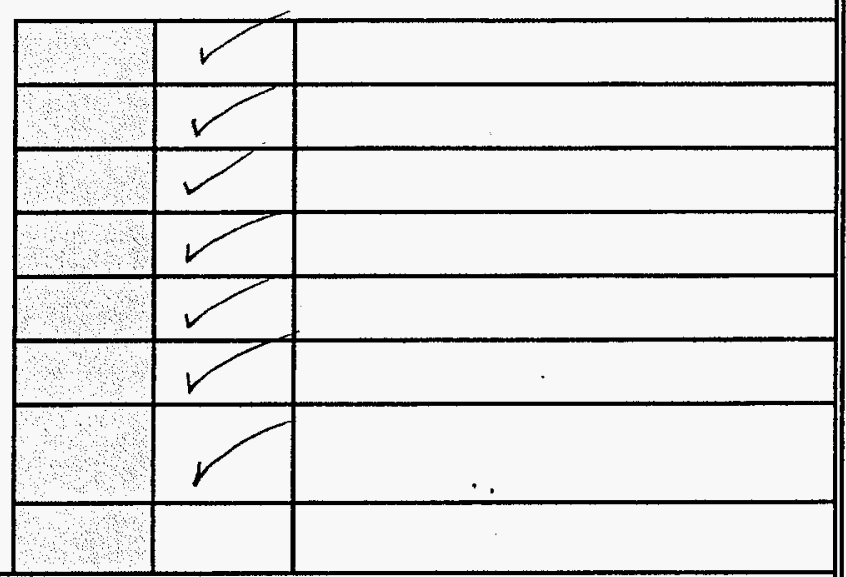

3. Monuments and other permanent features

a. Have the survey or boundary monuments been defaced or disturbed?

b. Have the site markers been disturbed by man or natural processes?

c. Do natural processes threaten the integrity of any monument or site marker?

d. Other?

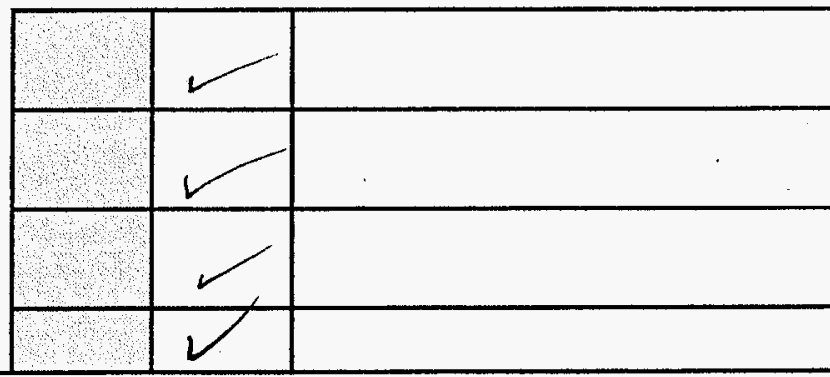

4. Area 6 Decontamination Pond RCRA Cover

a. Is there evidence of settling?

b. Is there cracking?

c. Is there evidence of erosion on the cover (wind or water)?

d. Is there evidence of animal burrowing?

e. Is there vegetation growing on the cover?

f. Is there standing water on the cover?

g. Other (including trash, debris, etc. within fenced area)?

SHOuLd not AFiECT THR unit

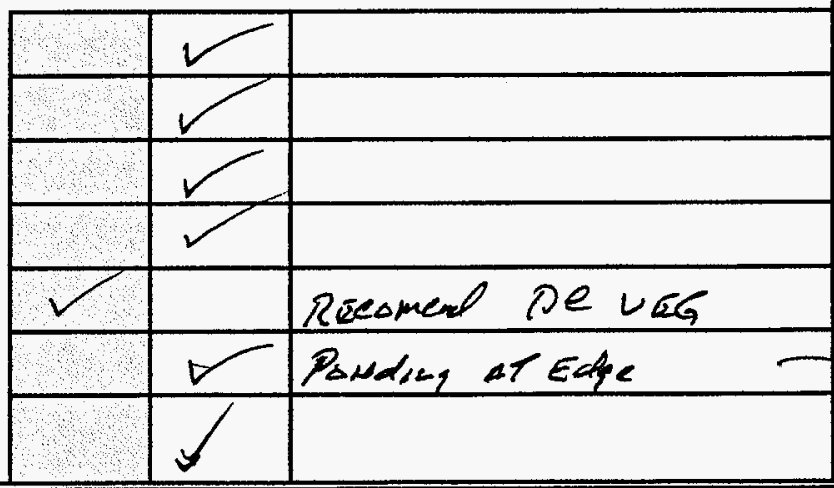




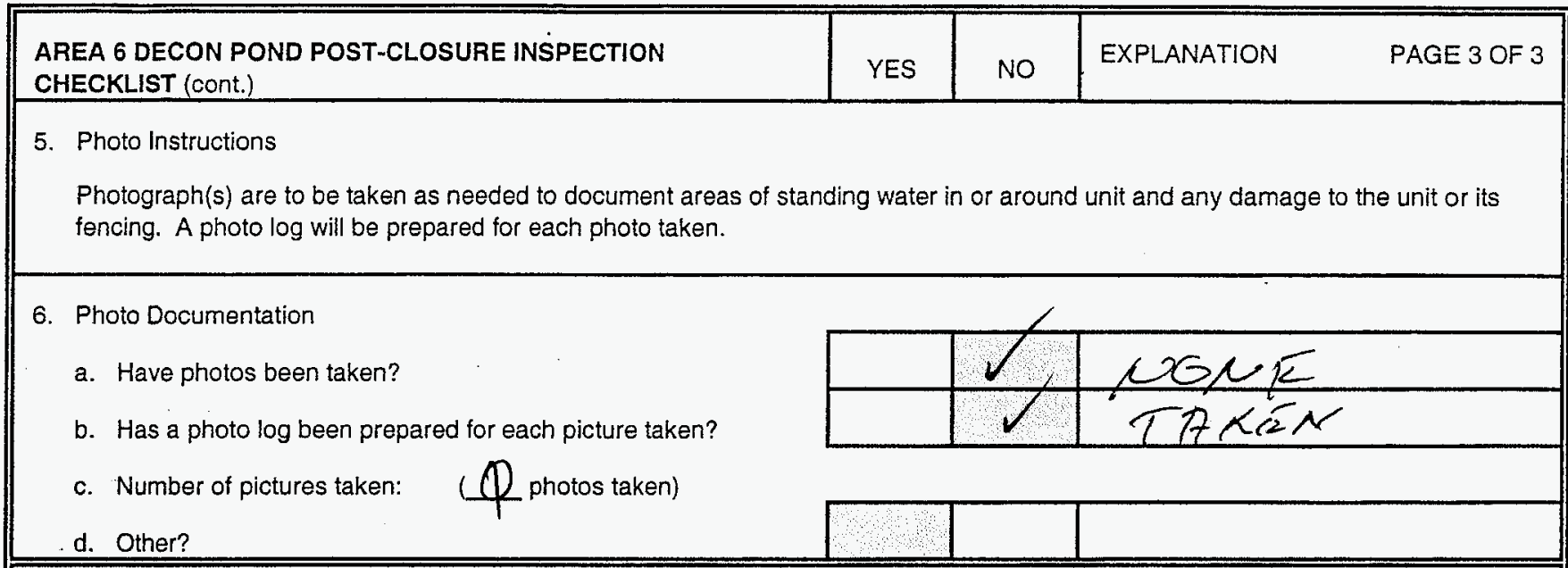

E. FIELD CONCLUSIONS

1. Is there an imminent hazard to the integrity of the Area 6 Decontamination Pond Cover? (Immediate report required)

Person/Agency to whom report made:

2. Are more frequent inspections required?

3. Are existing maintenance/repair actions satisfactory?

4. Is other maintenance/repair necessary?

5. Field conclusions/recommendations: ET APPEARS THAT THE WAT WAS in Good overall Condition, ALTHOUAR THE PRY LAKE Bed war full. THEe Surrounding. AReAs wine to

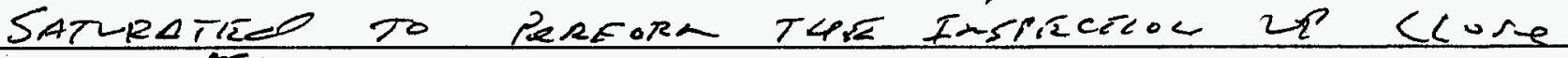
For Sanity Concerns. pHis uni Fencing Sisur, and wart Barrens, All Alpizak to Be

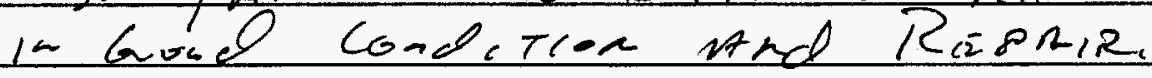

F. CERTIFICATION

I have conducted an inspection of the Area 6 Decontamination Pond Cover at the NTS in accordance with the procedures of the PostClosure Permit (including the Post-Closure Plan) as recorded on this checklist, attached sheets, field notes, photo logs, and photographs.

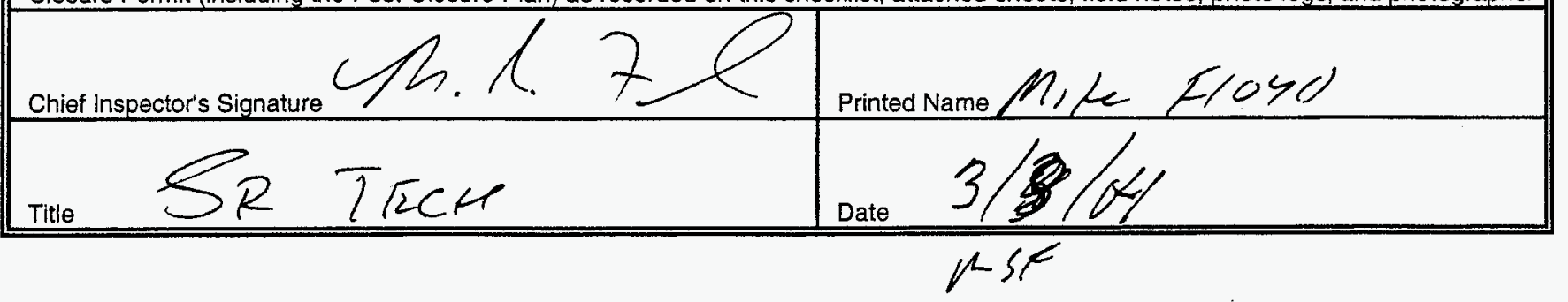


TITLE

Work continued from Page __ CAC 92
PROJECT NO.

BOOK NO.

$3 / 3 / 0.4$

93

Decen Pond Plackir Fusplaction.

Tr. Selacenw Bunison

TL Mike F104D

5

VISITOR STEFAM DUKe

EQune. NKA

10 Wrathar: Cool Ccome wind?

Scorr: Pizroinm Precur Euspuction

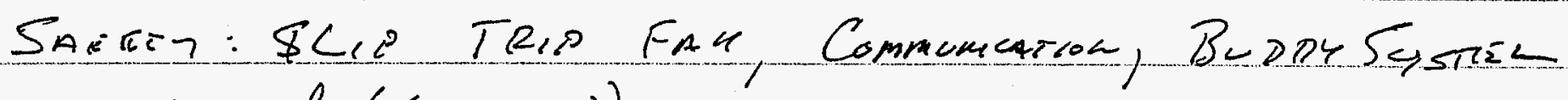
15 coirt Gavend (Satuatitio)

1145: araive at Site w/stzina- Duce kid found That THa CAY 92 DECON Pond whS TF WET. 20 To enter on the accass road. Fron wart herieases The Cag lever was in goel condifir. WAva Barain wite in soud cundition. Fencie's Aad Sigur wene Found To Be in jood Conditier.

25

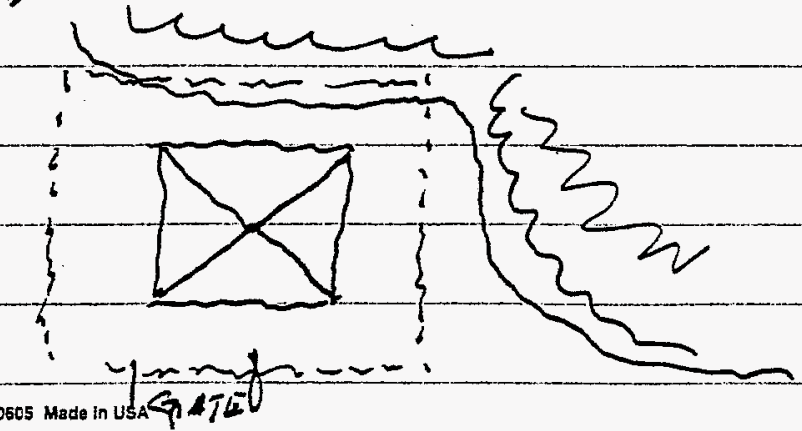

SCIENTITC EINDERY PRODUCTIONS CHICAGO 60605 Made in USA $5 / 4 T$

Work continued to Pageq5

SIGNATURE

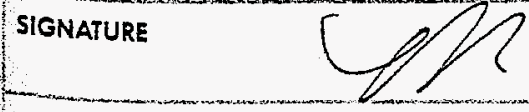

DISCLOSED TO AND UNDERSTOOD BY

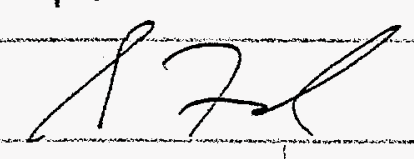

DATE

WITNESS

DATE

DATE 
TITLE

PROJECT NO.

95

Work continued from Page__ CAC 92 Cont.

BOOK NO.

THE UNT WAS Found TO BE in wHet APPGAREA TL Be Gond Condition, ACTHOUGA IT war found THat THE DRY Lake Whee Foll of Watkr (Sec Drawing 2 93). ON THE SOUTh Sids of THE Unit water was APPAOW 1-3 FEET from Fence line on East Side water was what ARranged TuBe at on Beyond THK

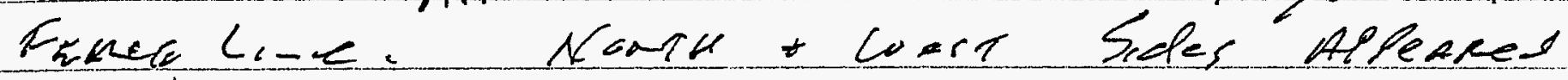
10 To Be day Bur very Serer

15

$20^{\circ}$

25

SCIENTIFIC BINDERY PRODUCTiONS CHICAGO 60605 Made in USA

SIGNATURE

DISCLOSED TO AND UNDERSTOOD BY
Work continued to Page Dafs/3/04

DATE

WITNESS

DATE 



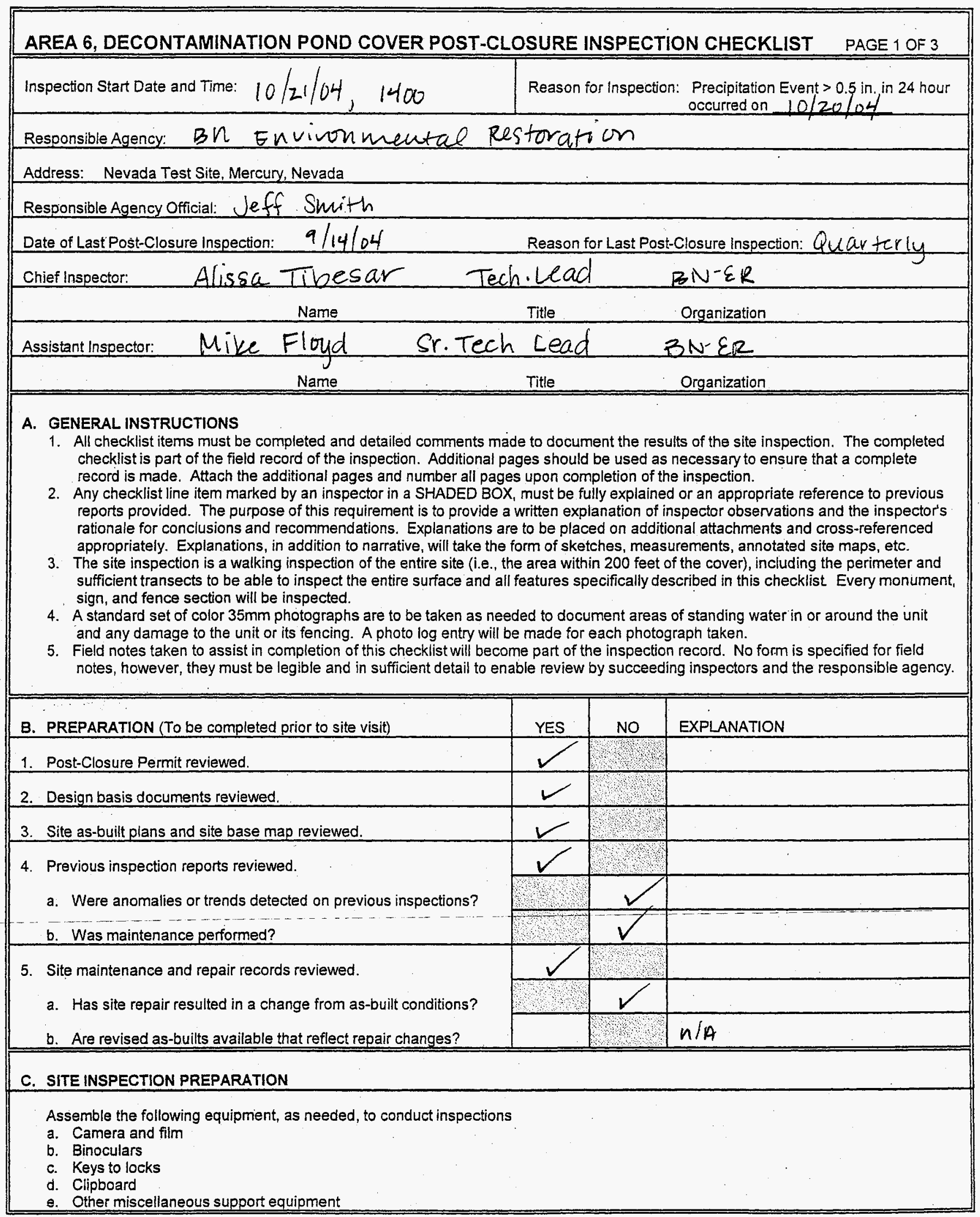




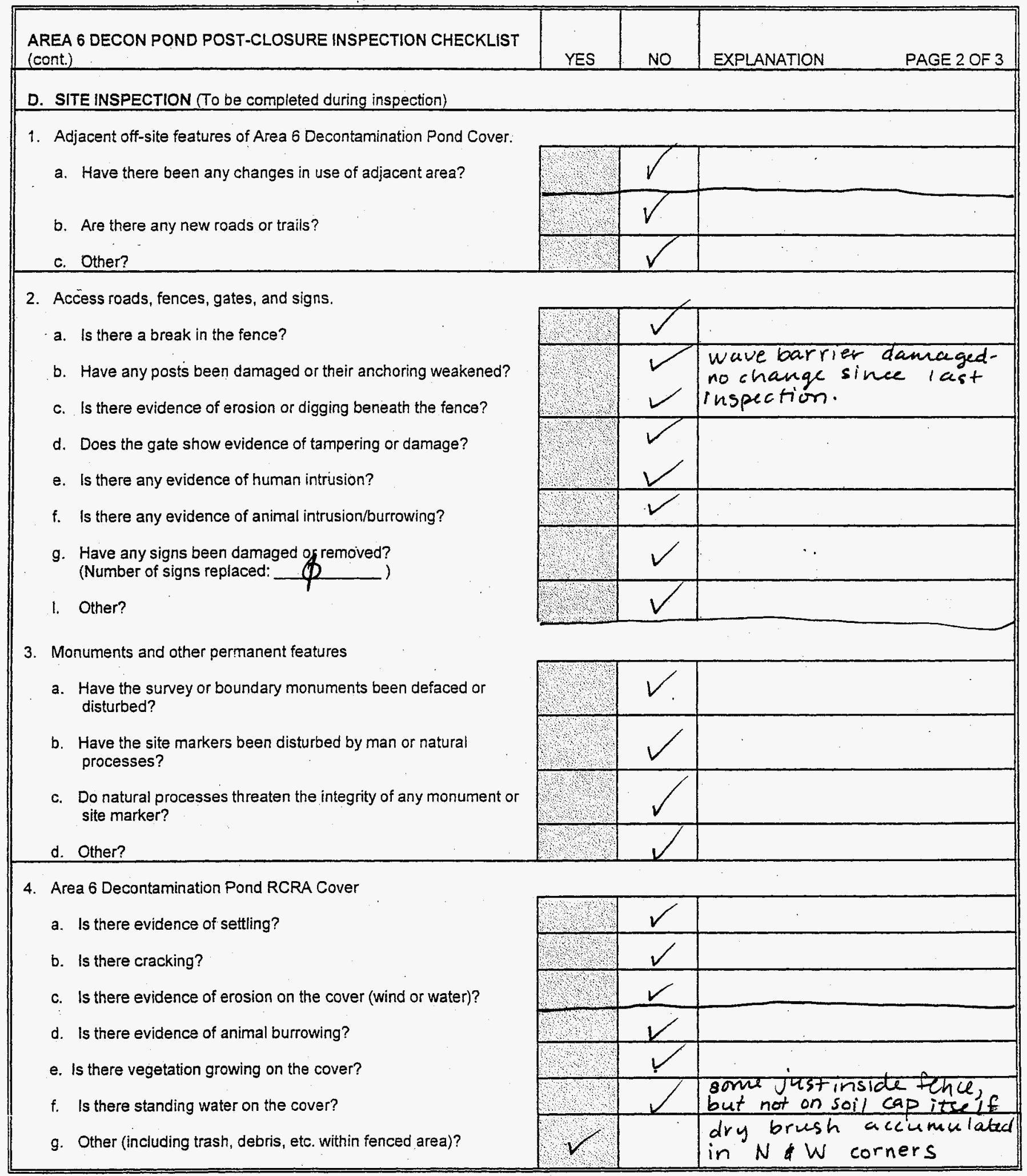




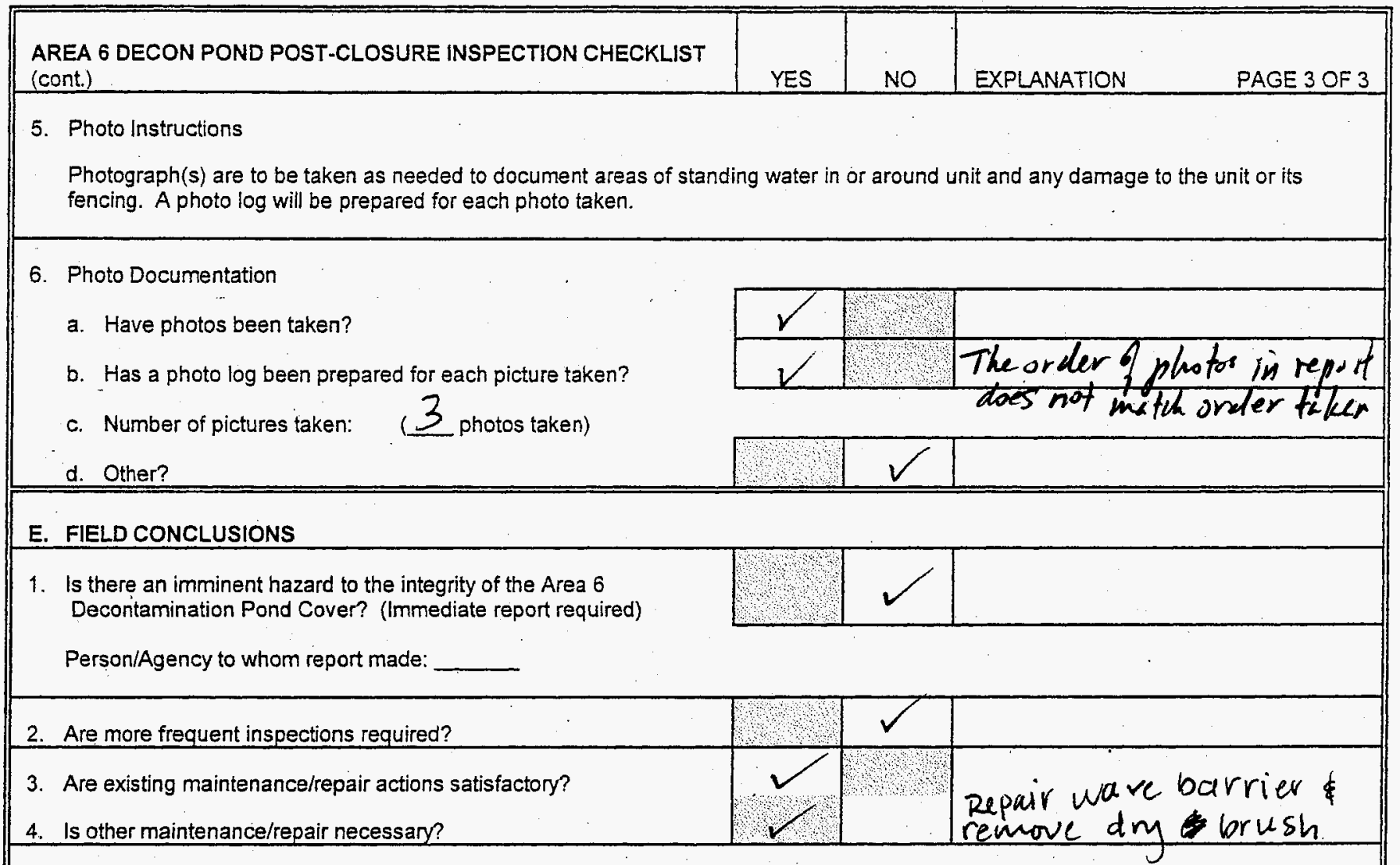

5. Field conclusions/recommendations:

The unit is in good condition. The precipitation event has not impacted the integrity of the whit. No standing water was on the soil cover.

\begin{tabular}{l} 
F. CERTIFICATION \\
I have conducted an inspection of the Area 6 Decontamination Pond Cover at the NTS in accordance with the procedures of the Post- \\
Closure Perantit (including the Post-Clesure Plan) as recorded on this checklist, attached sheets, field notes, photo logs, and photographs. \\
\hline Title Tech. Lead
\end{tabular}


24

PROJECT NO.

TITLE CAL 92 -Precip. Inspection

BOOK NO.

Work continued from Page $N / A$

$10 / 21 / 04$

Personell-Mike Floyd, Alissa Tibesar

visitors - None

Equipment - None

5 Weather - cloudy, cold,

Sow- Perform inspection of CAU 92-A-6. Decor Pond Facility

1:50- Departed Mercury for Area 6

2:10 -Arrived at CAM 92

- Fence, signs, cover- no change

- Some pounding noted just inside the fence, but not on the corer itself

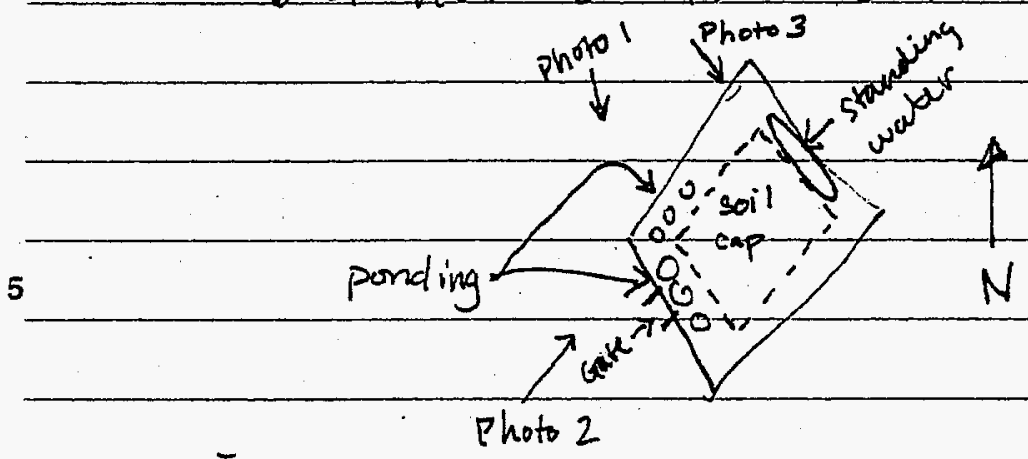

- Wave barrier still needs repair -no charge since last inspection.

- dry brush accumulation in North \& west corners no change since last inspection

- The precipitation event has not affected the integrity of the unit.

2:30 -Departed for Mercury

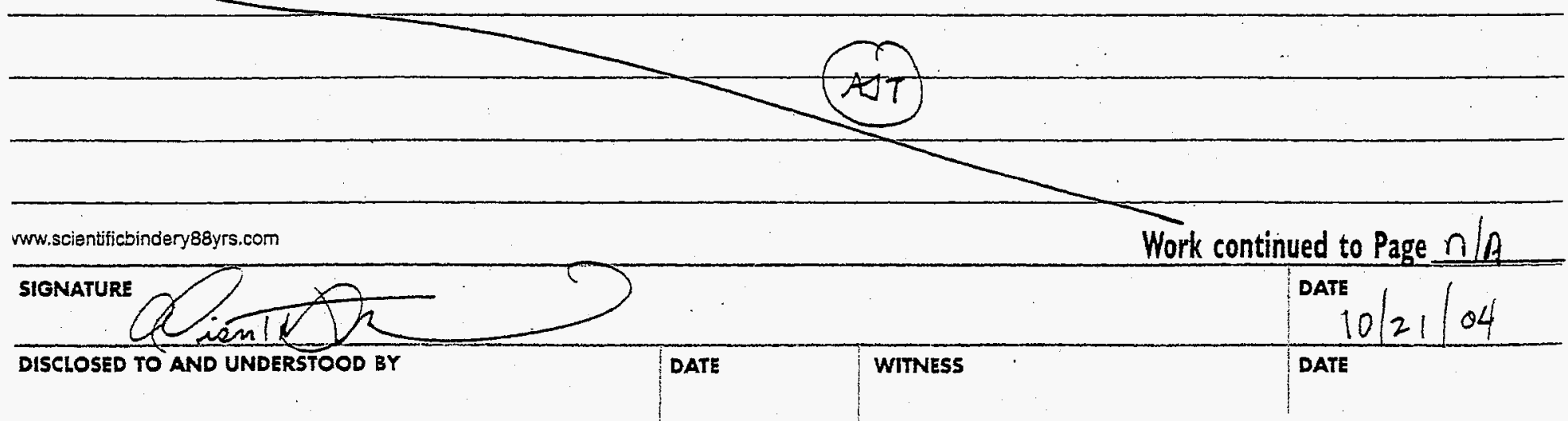




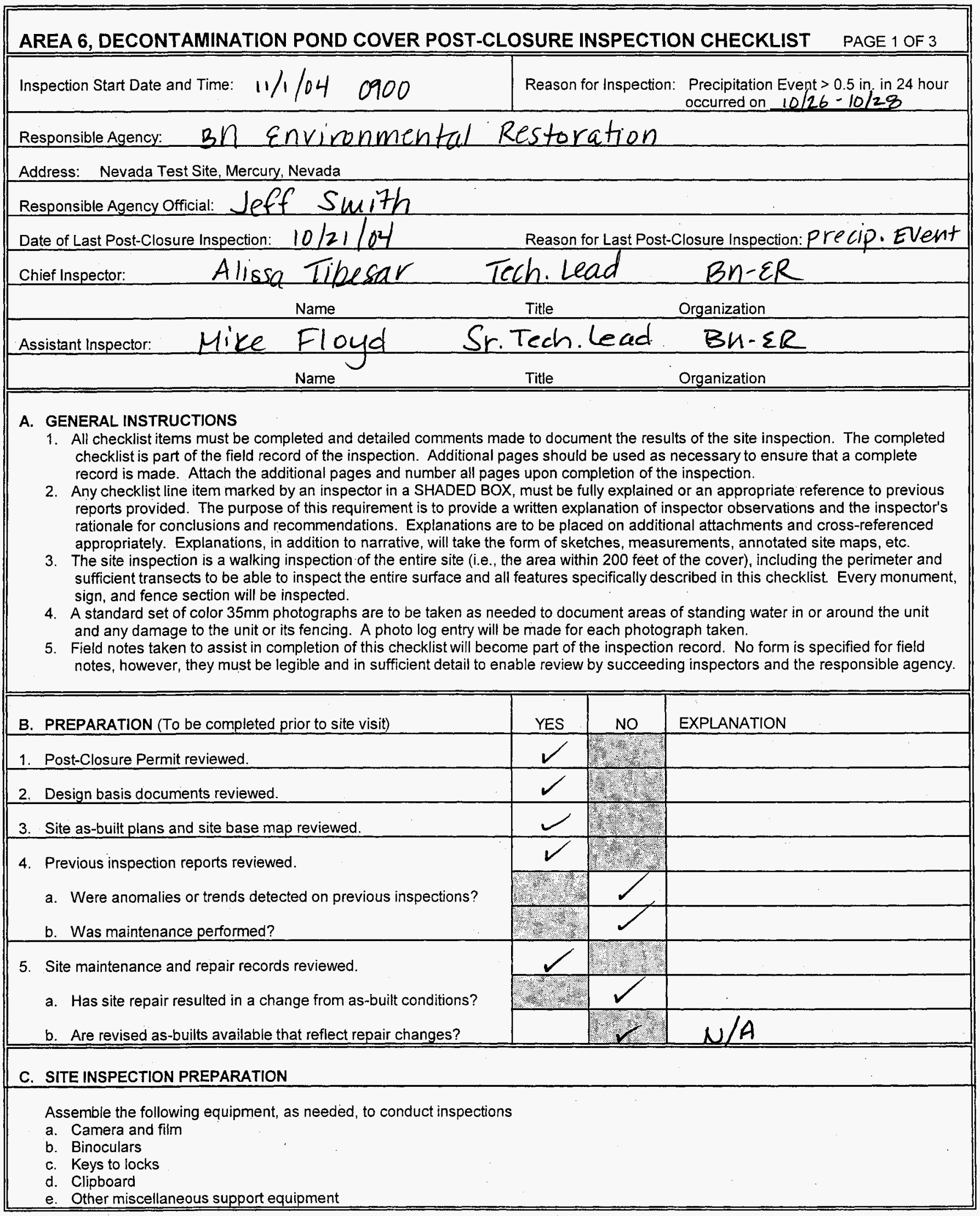




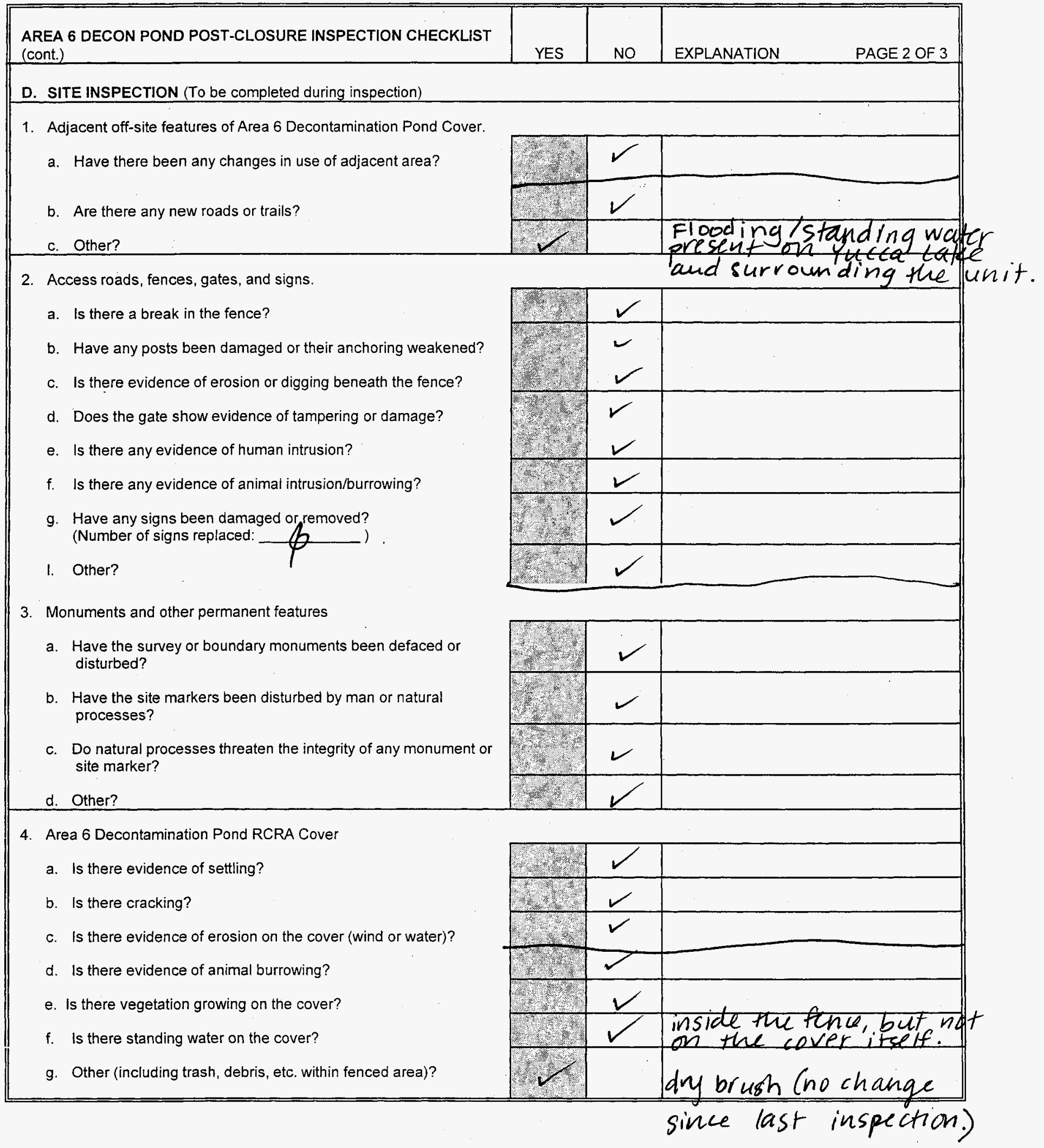


AREA 6 DECON POND POST-CLOSURE INSPECTION CHECKLIST (cont.)

5. Photo Instructions

Photograph(s) are to be taken as needed to document areas of standing water in or around unit and any damage to the unit or its fencing. A photo log will be prepared for each photo taken.

6. Photo Documentation

a. Have photos been taken?

b. Has a photo log been prepared for each picture taken?

c. Number of pictures taken:

d. Other?

E. FIELD CONCLUSIONS

1. Is there an imminent hazard to the integrity of the Area 6 Decontamination Pond Cover? (Immediate report required) Person/Agency to whom report made:

2. Are more frequent inspections required?

3. Are existing maintenance/repair actions satisfactory?

4. Is other maintenance/repair necessary?

5. Field conclusions/recommendations:

There was flooding/standing water around the unit, but not on the soil cover itself. The precipitation event has not affected the integrity of the unit.

F. CERTIFICATION

I have conducted an inspection of the Area 6 Decontamination Pond Cover at the NTS in accordance with the procedures of the PostClosure Permit (including the Post-Closure Plan) as recorded on this checklist, attached sheets, field notes, photo logs, and photographs.

\begin{tabular}{|l|l|}
\hline & ALISSA TIBESTi \\
\hline Title Inspector's Signature & Printed Name \\
\hline
\end{tabular}


TITLE CAUl 92 Precip.inspection

Work continued from Page $N / A$
PROJECT NO. BOOK NO.

29

$11 / 1 / 04$

CAL 92. Area 6 Recon Pond Facility

Personell-Mike Floyd, Alissa Tibesar (TLS)

visitors -none

5 Equipment -None

weather cold, clear

Sow -Perform inspection of CAU 92

9:00. Arrived at CAU 92

10

15

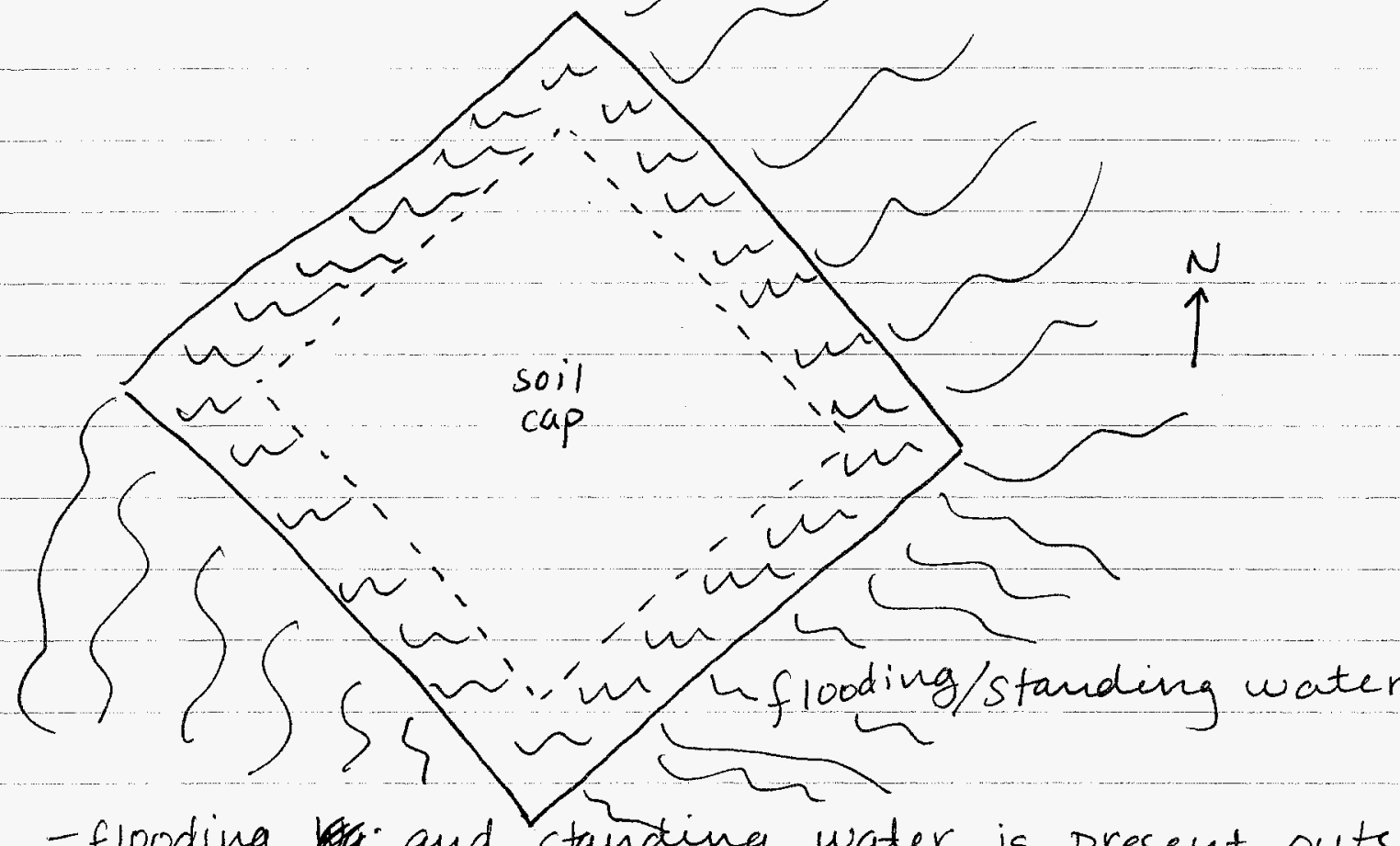

20

- flooding and standing water is present outside the fence on three sides of the unit (all except NW side)

- standing water is present inside the fence, but not on the soil cap itself.

- No change in the condition of the fence, signs, monomer 25

- No change in brush accumulation since last inspection

- The precipitation event has not affected the integrity of the unit.

- 7 photos were taken of the cover.

www.scientificbindery88yrs.com

Work continued to Page N/A

SIGNATURE

DATE
$n / 1 / 04$

WITNESS

DATE 


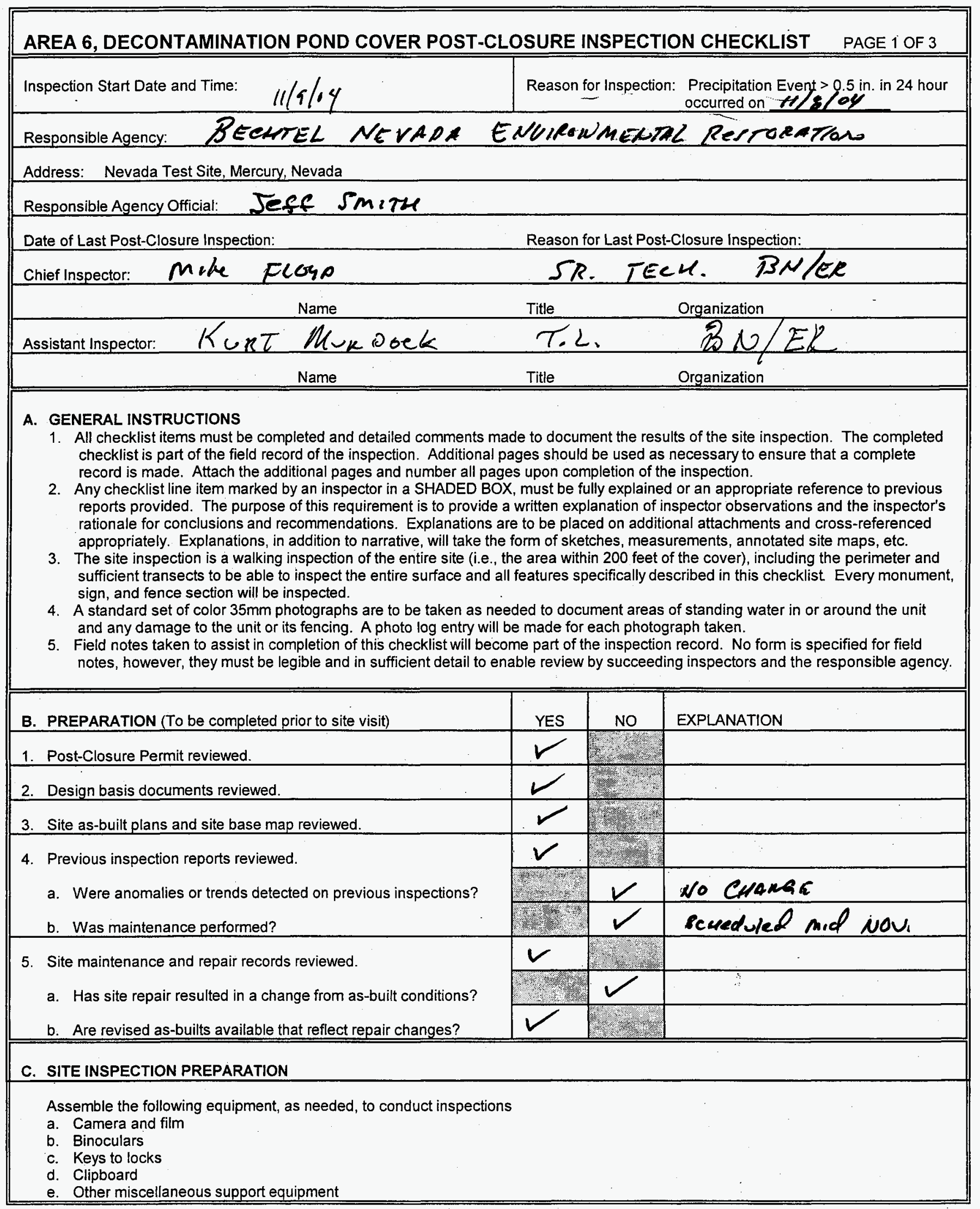




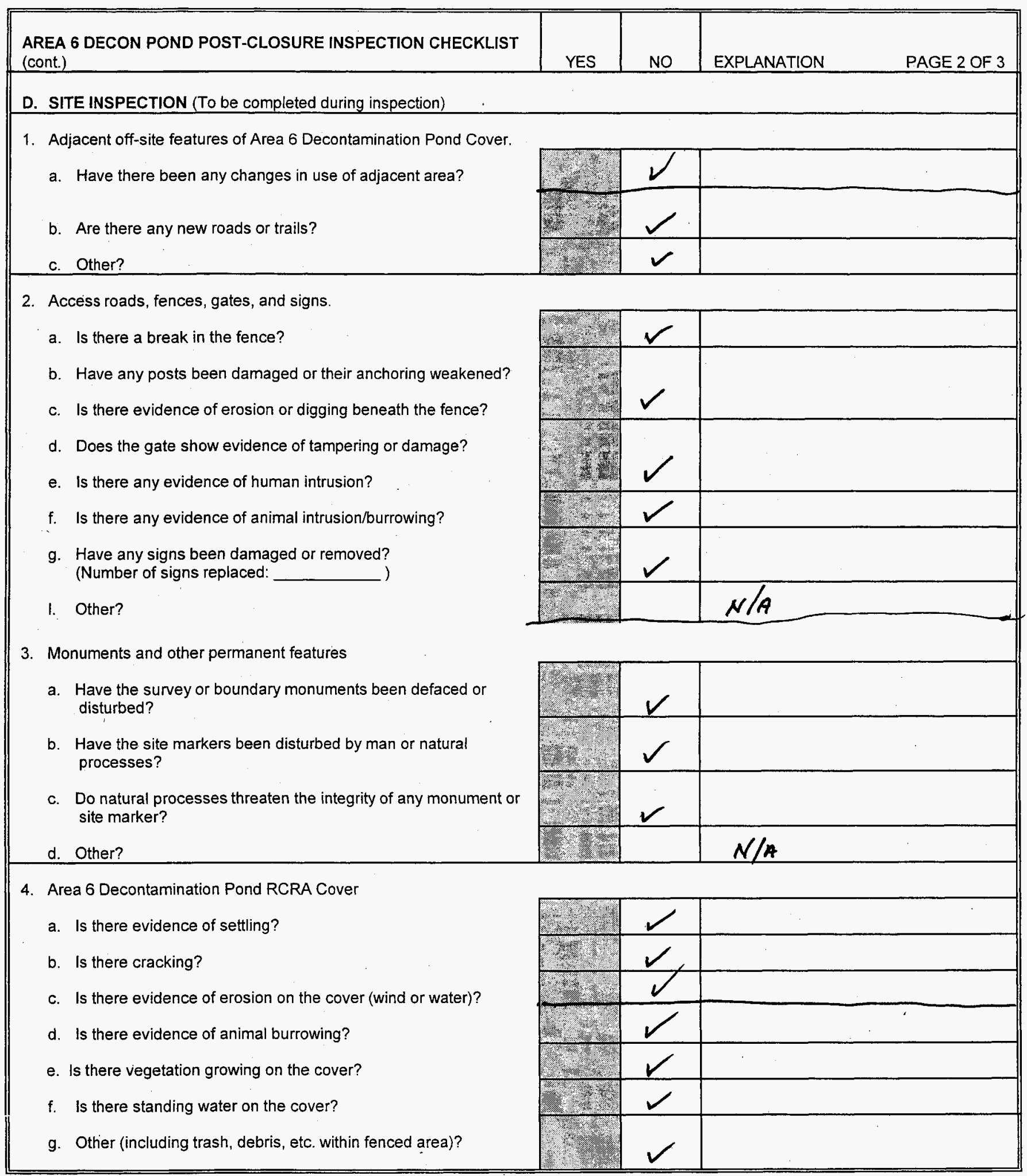




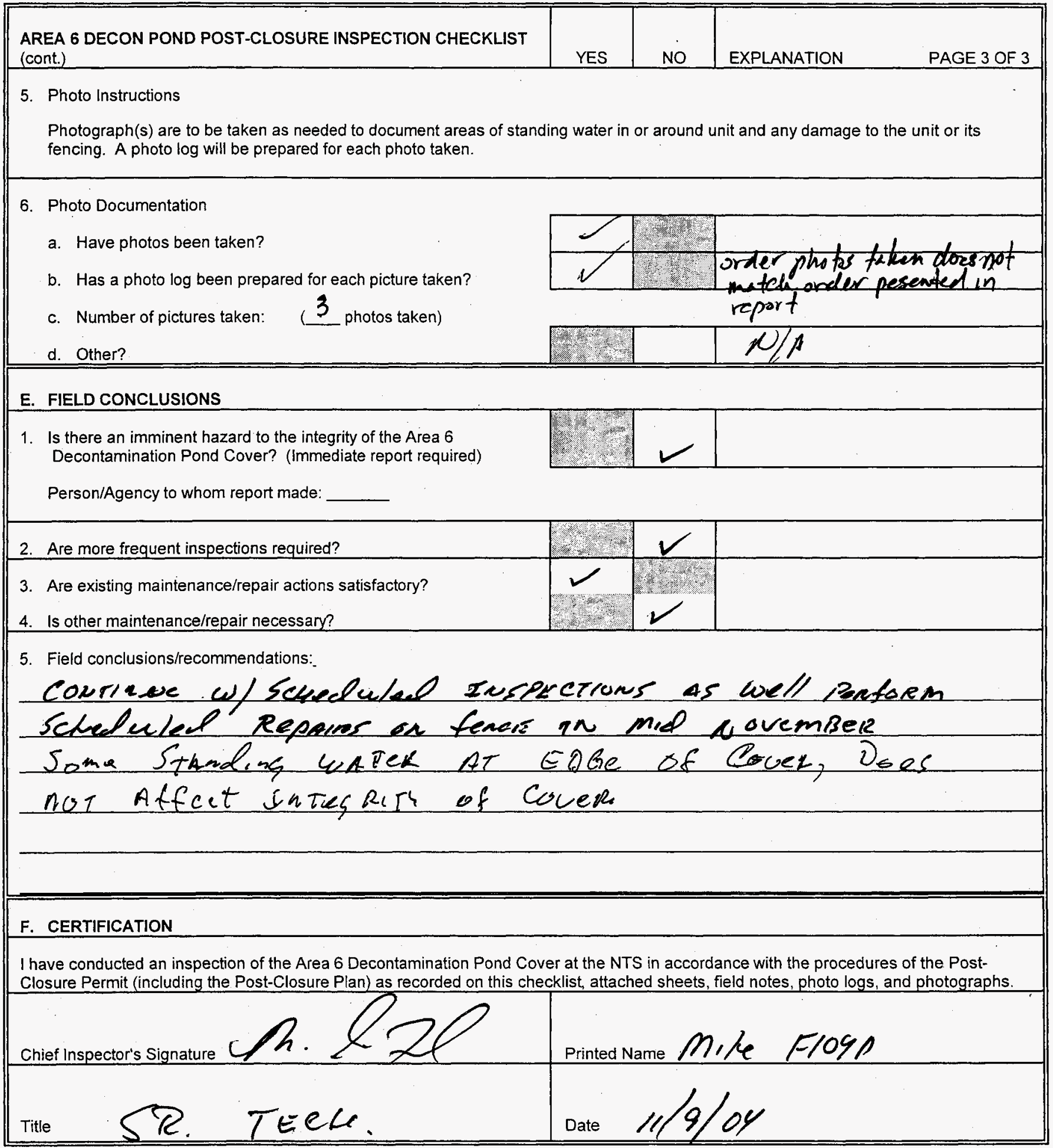


TITLE
Work continued from Page

PROJECT NO.

BOOK NO.

Weather

$60^{\circ}$

Tuesday November $9^{74}, 2004$ Cloud u Area 6 CAl 92 CAS 06-05.02 wet

Precis Event on 11-8-or

5 Safety topic: Slip/trip/Fall, muddy driving cone., buddy System, watch for Biological Hay.

Personnel

$2 T L$ Runt Murdoch

Mike Floyd

- Scope: Perform C AU 92 precipitation inspection

Visitors: vane

Equipment: None

15 2:25 Amie at cAl 92

- Note: Standing water around edge of Cap

mi - - - See photo -will not affect the cap.

- Fence: good condition besides where repair was ahead needed.

20

- Signs in place, good condition.

- Gates: locked

3:00 leave site

25

www.scientificbindery88yrs.com

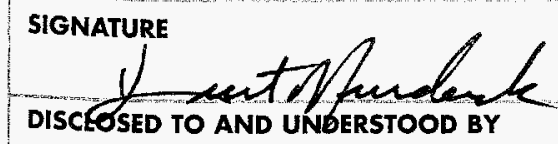

Work continued to Page

DATE

11-9-OY 


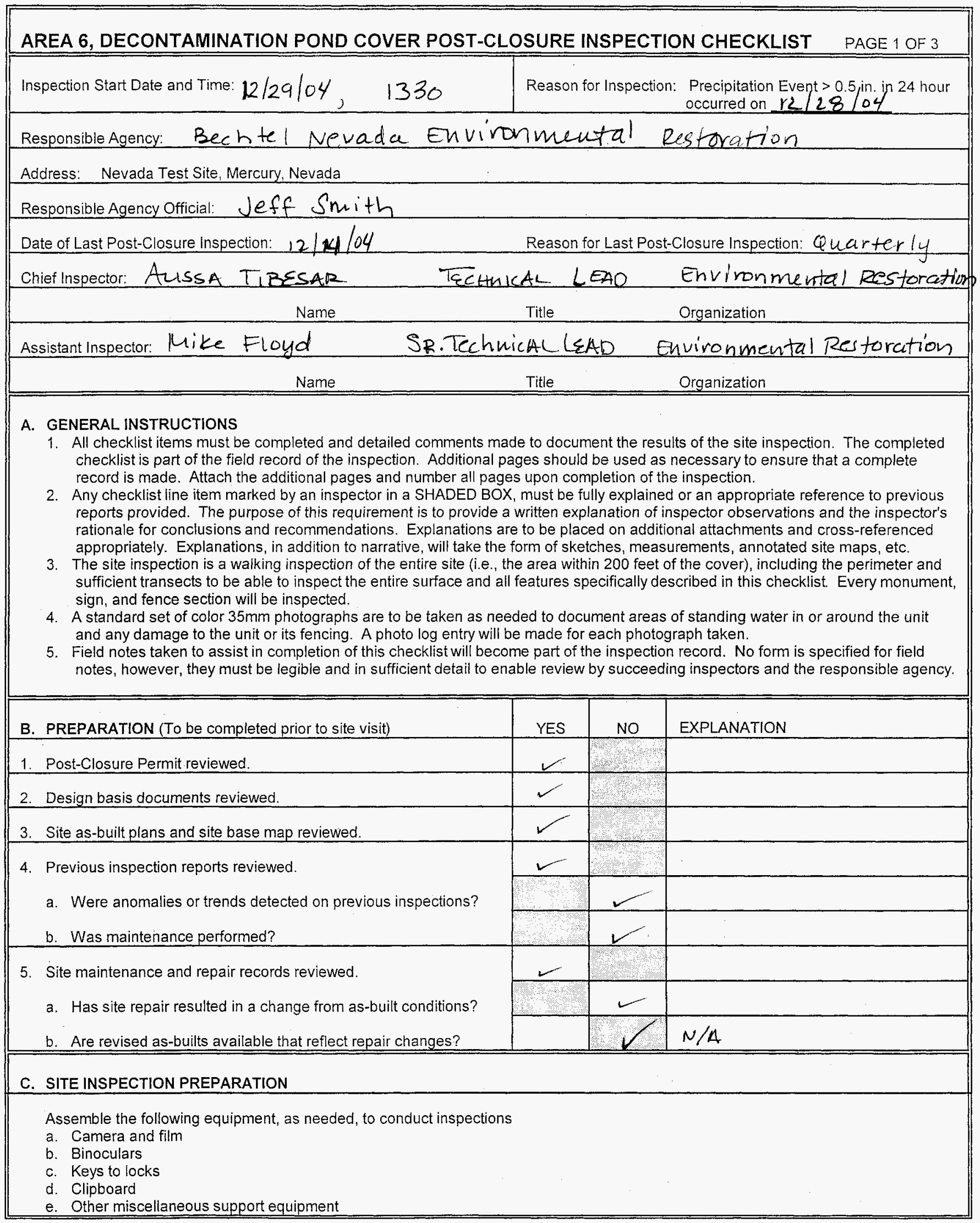




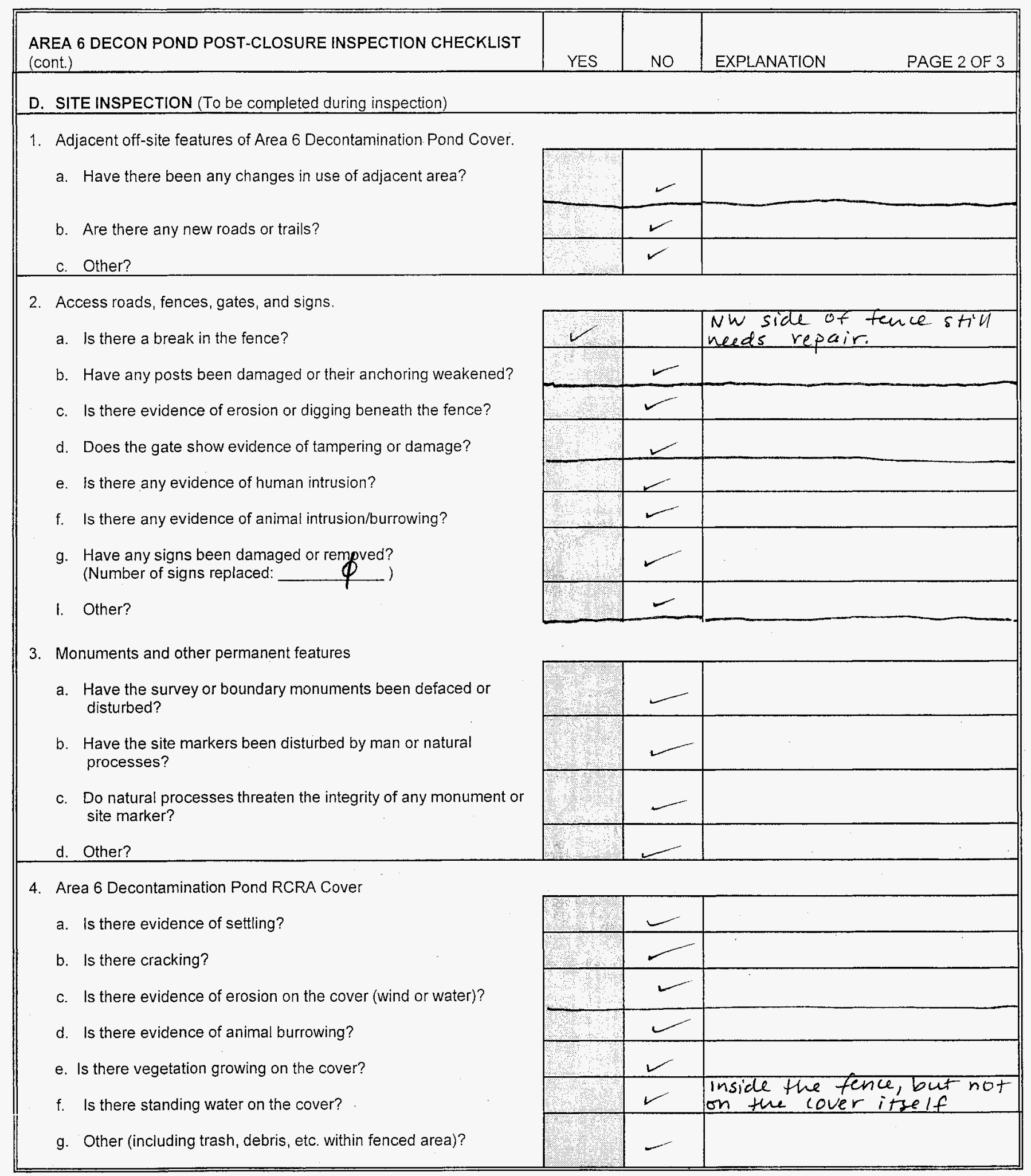




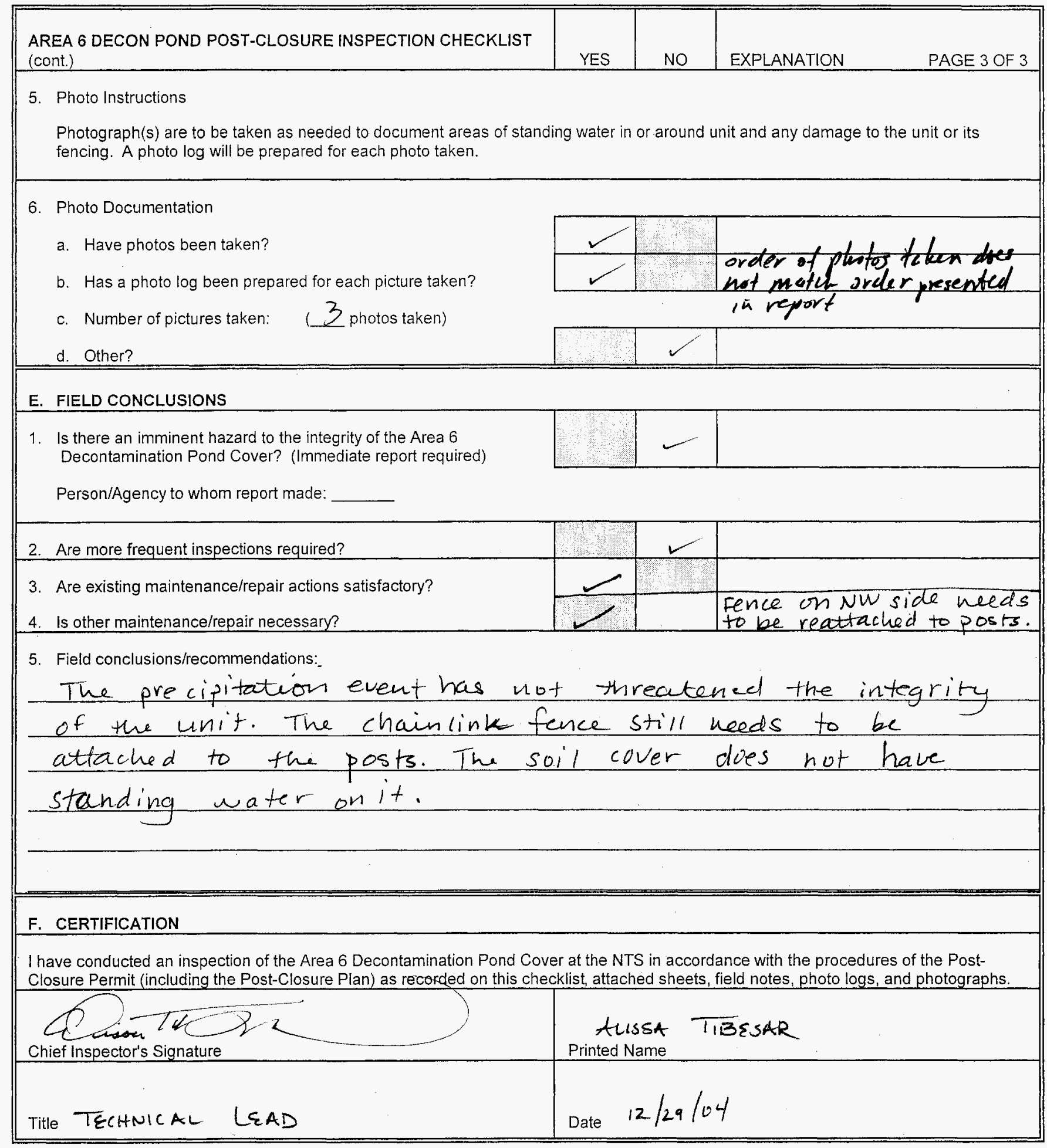


46

PROJECT NO. BOOK NO.
TITLE Precip Inspection CAU 92

Work continued from Page $\mathrm{N} / \mathrm{A}$

$12 / 29 / 04$

Personnel- AlisSa Tibrsar (TL), MIKE FLOYD (TL)

VISITORS. NONE

EQUIPMENT - NONE

5 WEATHER -cloudy, windy, COLO, 40's

Sow -Inspect CAM 92 - Area 6 Deon Pond Facility

SAFETY TopICS - SLPS/Trips/Fall, buddy system, driving safety, communications, cold stress, Food watch, Bio Hazards

1315-Leave mercury for Area 6 , called Bird dg on soc Net to inform 0 them of our activities.

1345 - Arrived at the site.

Pounding within the fenced area, not on the soil cover itself, is present. The integrity of the unit has not been affected. The chain link fence has come away from the posts \& has worsened. It will be repaired as soon as weather permits

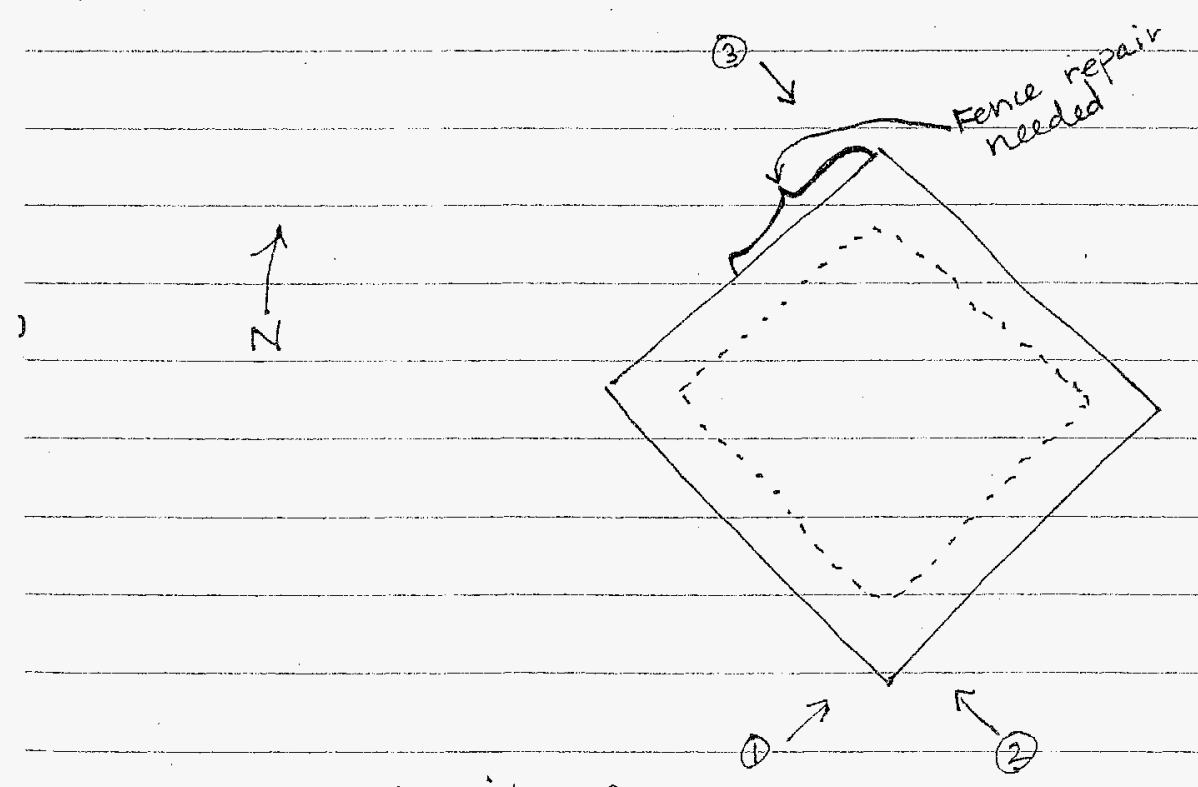

1400 - Departed site for Mercury.

www.scientificbindery88yrs.com

SIGNATURE

DISCLOSED TO AND UNDERSTOOD BY
Work continued to Page $\mathrm{M} / \mathrm{A}$

DATE $12 / 24 / 04$

WITNESS

DATE 
Post-Closure Report - CAU 92

Revision: 0

Date: March 2005

\section{APPENDIX B}

\section{PHOTOGRAPHS}


Post-Closure Report - CAU 92

Revision: 0

Date: March 2005

\section{THIS PAGE INTENTIONALLY LEFT BLANK}




\section{PHOTOGRAPH LOG}

\begin{tabular}{|c|c|c|}
\hline PHOTOGRAPH & DATE & DESCRIPTION \\
\hline 1 & $2 / 5 / 2004$ & Outside looking northeast \\
\hline 2 & $2 / 5 / 2004$ & Outside looking northwest \\
\hline 3 & $2 / 5 / 2004$ & Outside looking west \\
\hline 1 & $3 / 22 / 2004$ & Outside unit looking north \\
\hline 2 & $3 / 22 / 2004$ & Outside unit looking east \\
\hline 3 & $3 / 22 / 2004$ & Outside unit looking south \\
\hline 4 & $3 / 22 / 2004$ & Outside unit looking west \\
\hline 5 & $3 / 22 / 2004$ & Inside unit looking north \\
\hline 6 & $3 / 22 / 2004$ & Inside unit looking east \\
\hline 7 & $3 / 22 / 2004$ & Inside unit looking south \\
\hline 8 & $3 / 22 / 2004$ & Inside unit looking west \\
\hline 1 & $6 / 23 / 3004$ & Outside unit looking north \\
\hline 2 & $6 / 23 / 3004$ & Outside unit looking east \\
\hline 3 & $6 / 23 / 3004$ & Outside unit looking south \\
\hline 4 & $6 / 23 / 3004$ & Outside unit looking west \\
\hline 5 & $6 / 23 / 3004$ & Inside unit looking north \\
\hline 6 & $6 / 23 / 3004$ & Inside unit looking east \\
\hline 7 & $6 / 23 / 3004$ & Inside unit looking south \\
\hline 8 & $6 / 23 / 3004$ & Inside unit looking west \\
\hline 1 & $9 / 14 / 2004$ & Outside unit looking north \\
\hline 2 & $9 / 14 / 2004$ & Outside unit looking east \\
\hline 3 & $9 / 14 / 2004$ & Outside unit looking south \\
\hline 4 & $9 / 14 / 2004$ & Outside unit looking west \\
\hline 5 & $9 / 14 / 2004$ & Inside unit looking north \\
\hline 6 & $9 / 14 / 2004$ & Inside unit looking east \\
\hline 7 & $9 / 14 / 2004$ & Inside unit looking south \\
\hline 8 & $9 / 14 / 2004$ & Inside unit looking west \\
\hline 1 & $10 / 21 / 2004$ & Outside unit looking southeast \\
\hline 2 & $10 / 21 / 2004$ & Outside unit looking northeast \\
\hline 3 & $10 / 21 / 2004$ & Outside unit looking east \\
\hline 1 & $12 / 14 / 2004$ & Outside unit looking north \\
\hline 2 & $12 / 14 / 2004$ & Outside unit looking east \\
\hline
\end{tabular}


Date: March 2005

\begin{tabular}{|c|c|l||}
\hline PHOTOGRAPH & DATE & \multicolumn{1}{|c|}{ DESCRIPTION } \\
\hline \hline 3 & $12 / 14 / 2004$ & Outside unit looking south \\
\hline 4 & $12 / 14 / 2004$ & Outside unit looking west \\
\hline 5 & $12 / 14 / 2004$ & Inside unit looking north \\
\hline 6 & $12 / 14 / 2004$ & Inside unit looking east \\
\hline 7 & $12 / 14 / 2004$ & Inside unit looking south \\
\hline 8 & $12 / 14 / 2004$ & Inside unit looking west \\
\hline 1 & $12 / 29 / 2004$ & Outside unit looking northeast \\
\hline 2 & $12 / 29 / 2004$ & Outside unit looking northwest \\
\hline 3 & $12 / 29 / 2004$ & Outside unit looking southeast \\
\hline
\end{tabular}




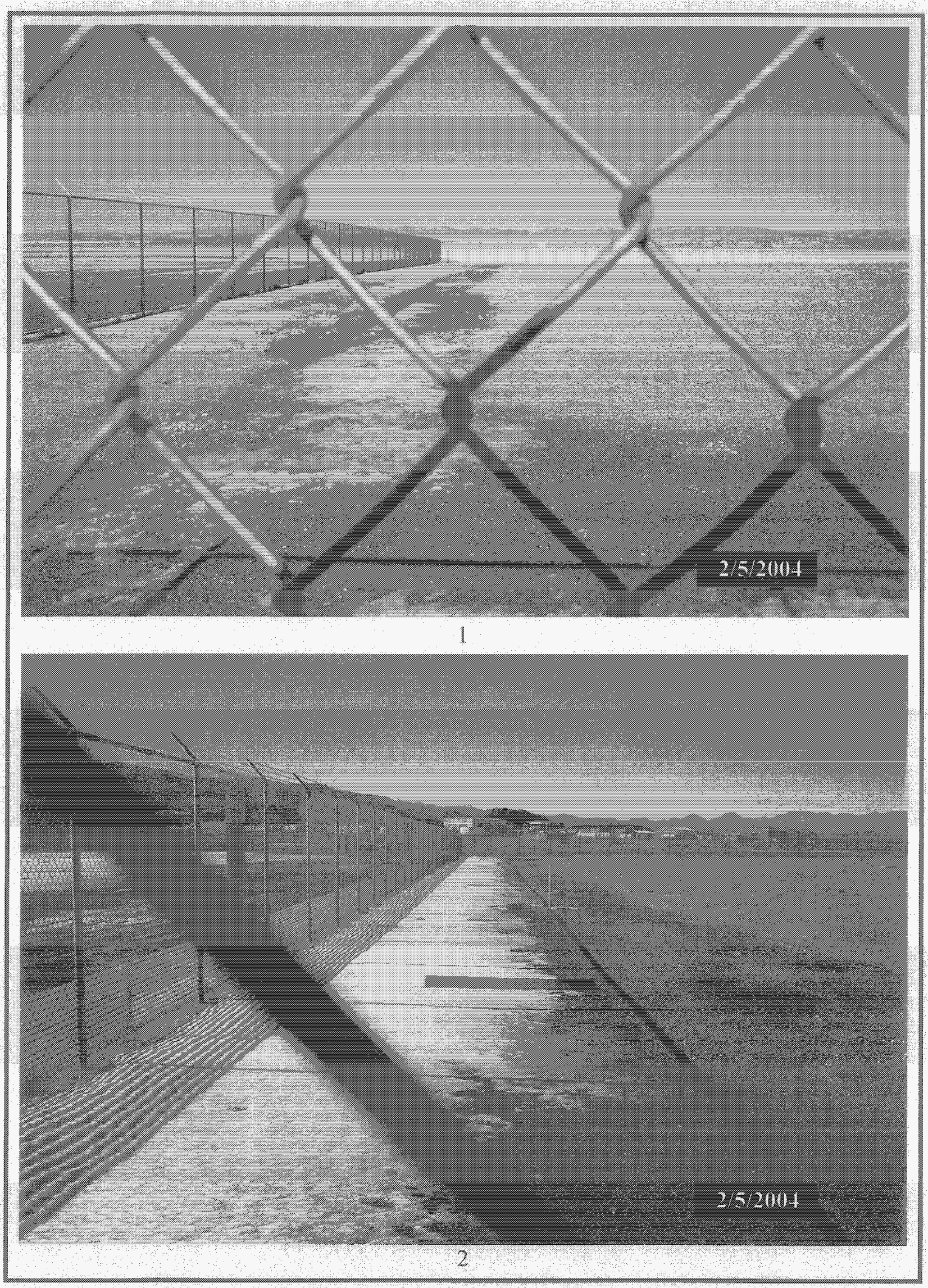


Post-Cosure Roport - CAU 92

Revision:

Wate: Mard 2005

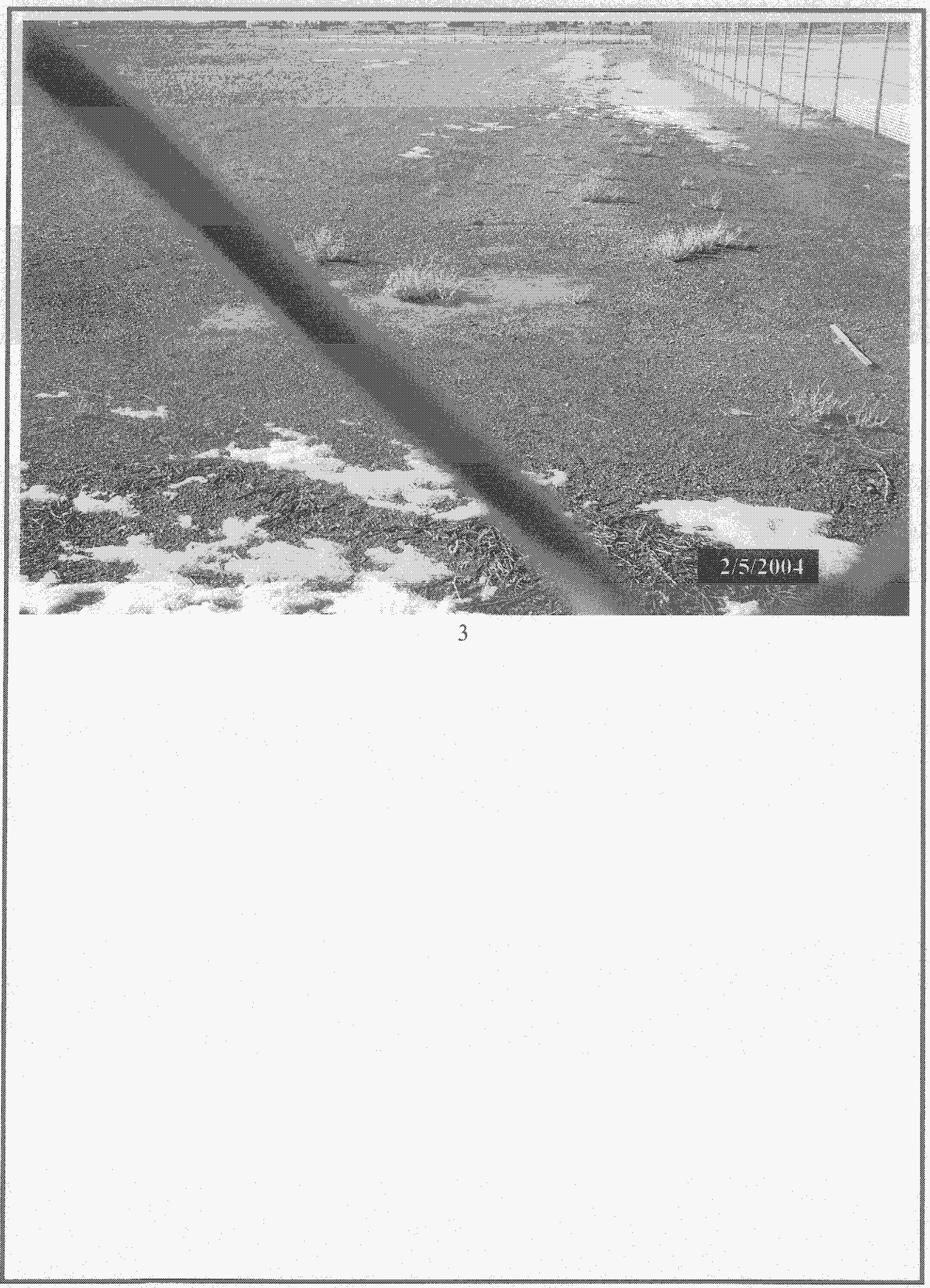


Post Closuth Rowort - CAU 92

Revision: 0

Date: Nameh 2005

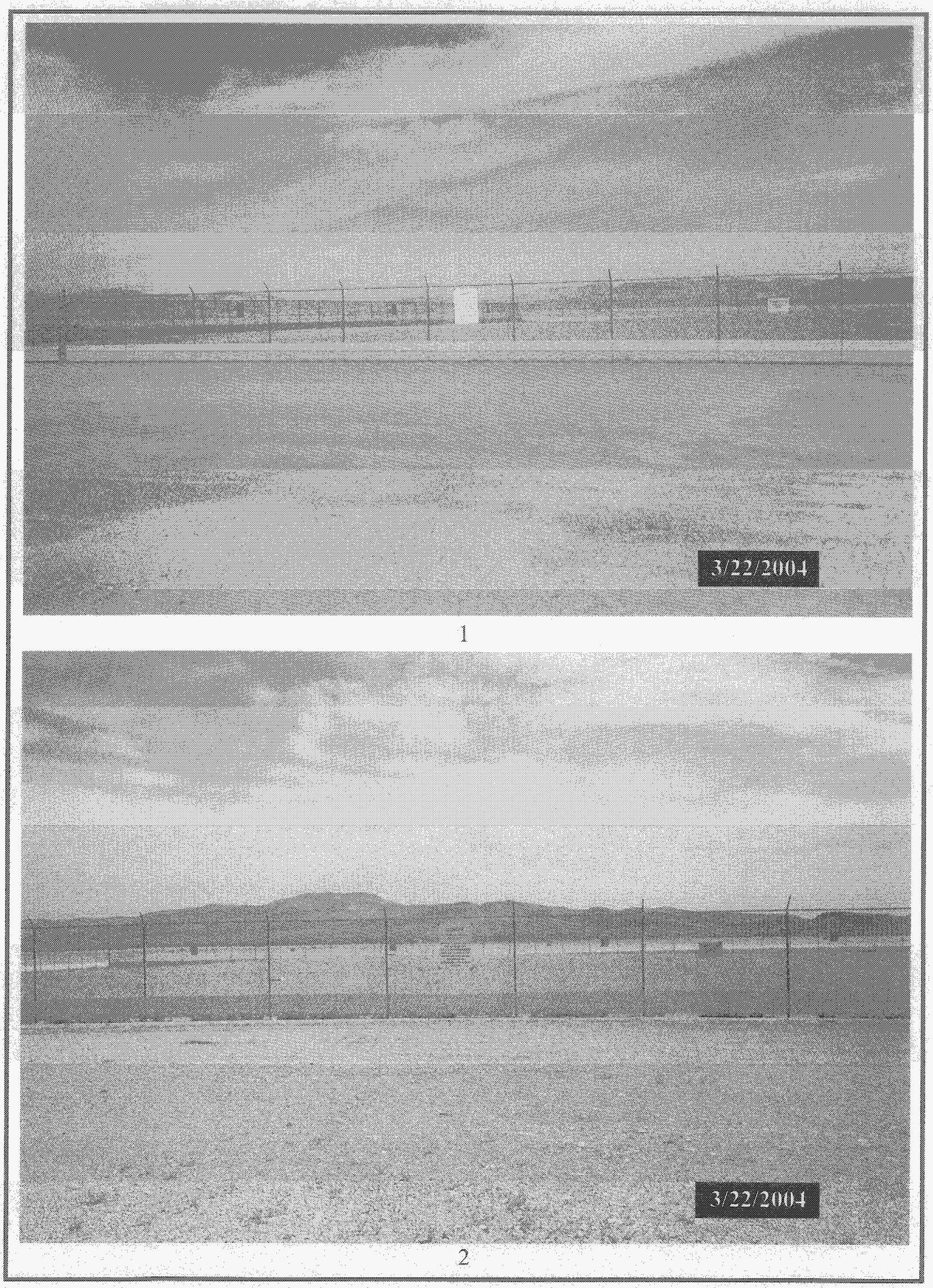


Mot-Closure Repon -. CAU S2

Revision:

Data: March 2005

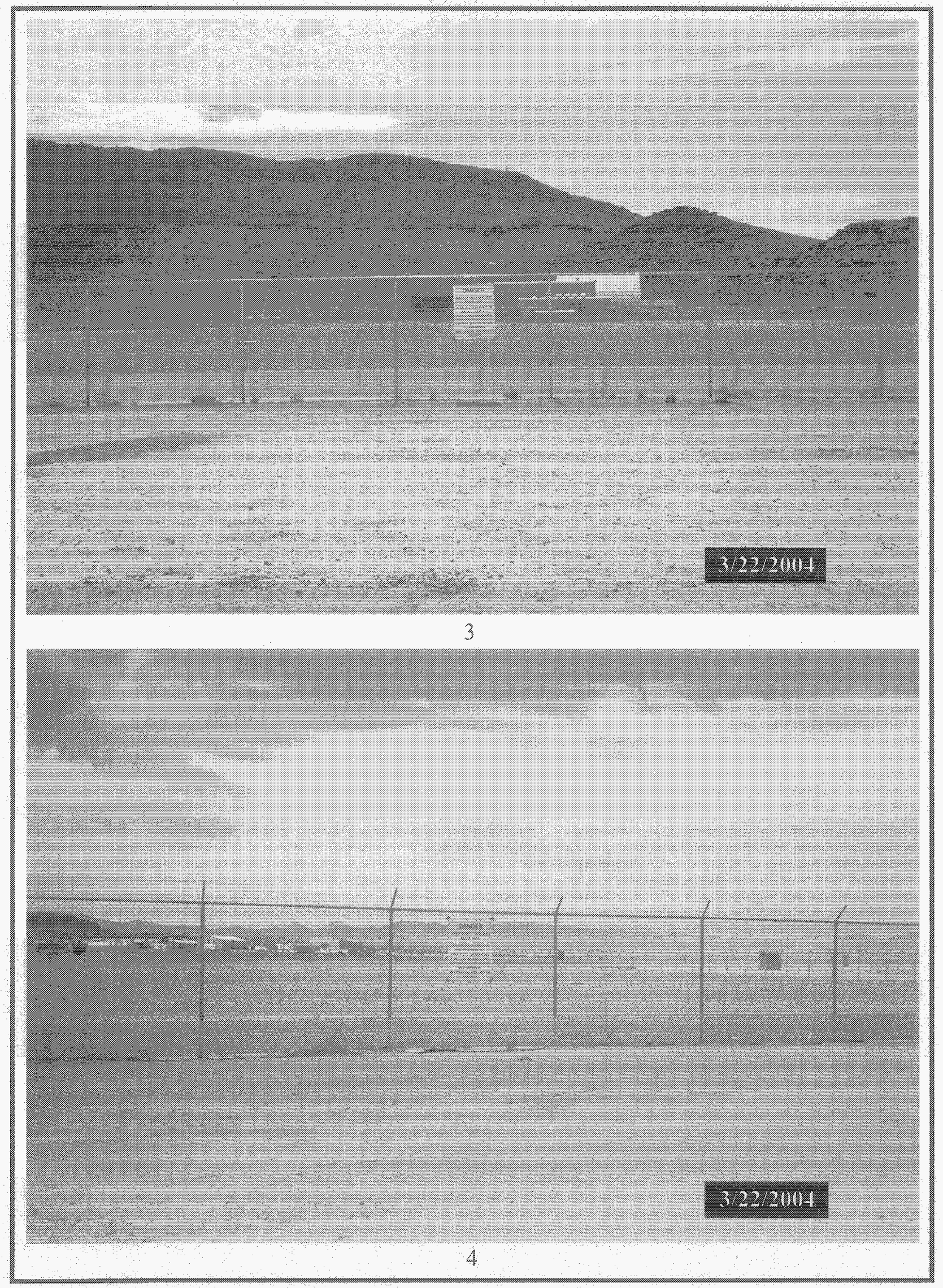




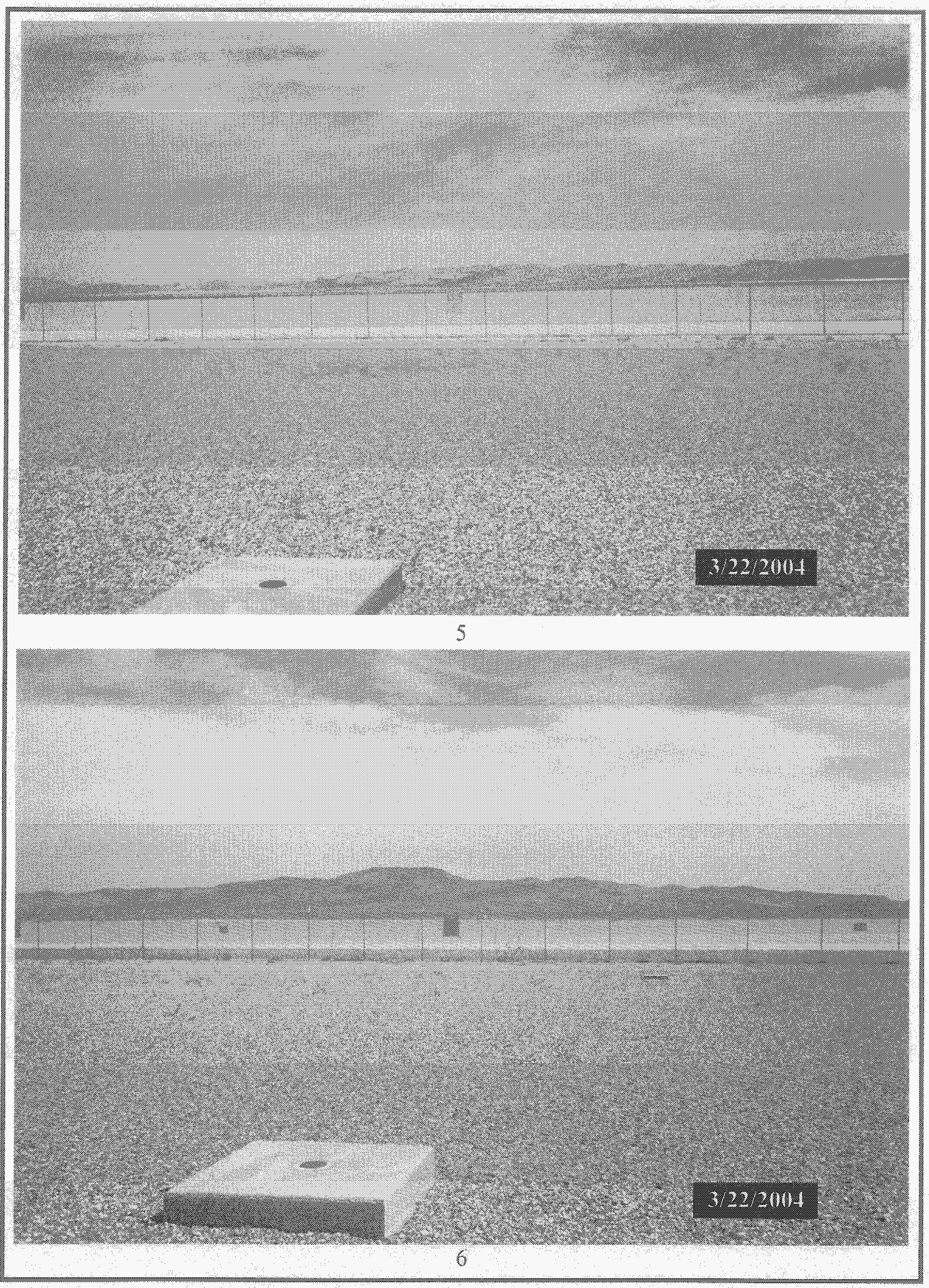




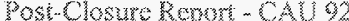

Revision: 0

Date: March 2Ws

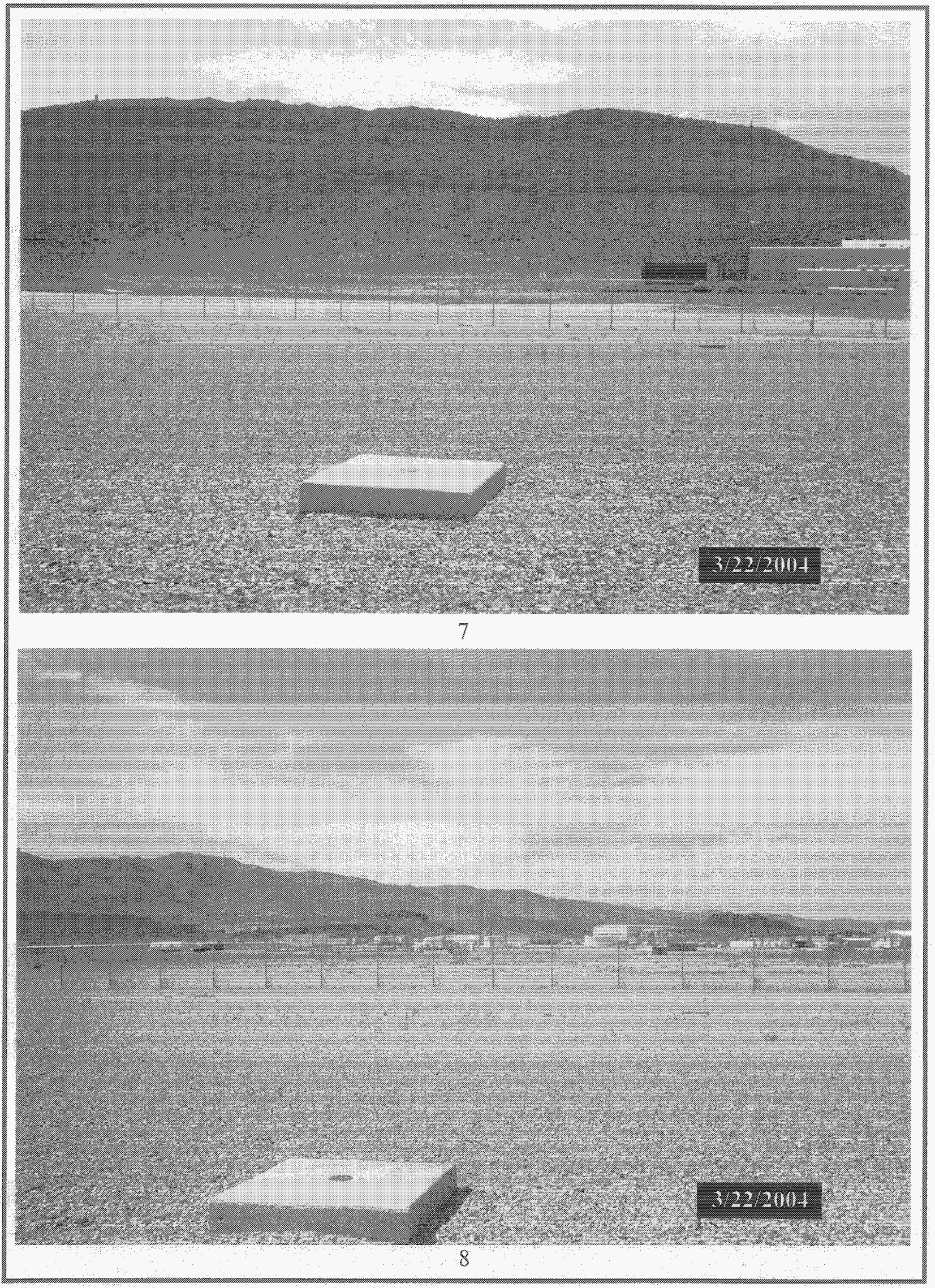




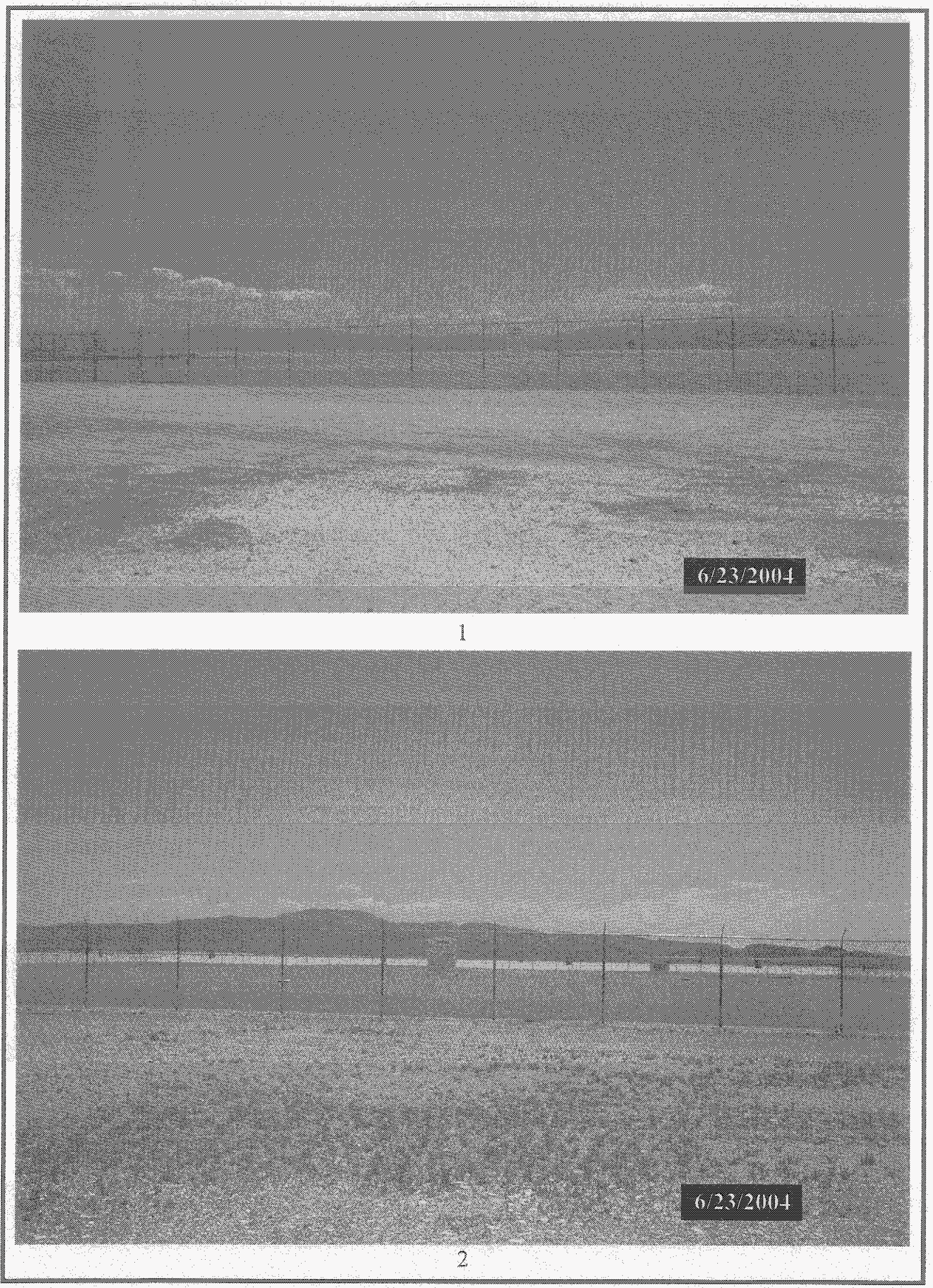




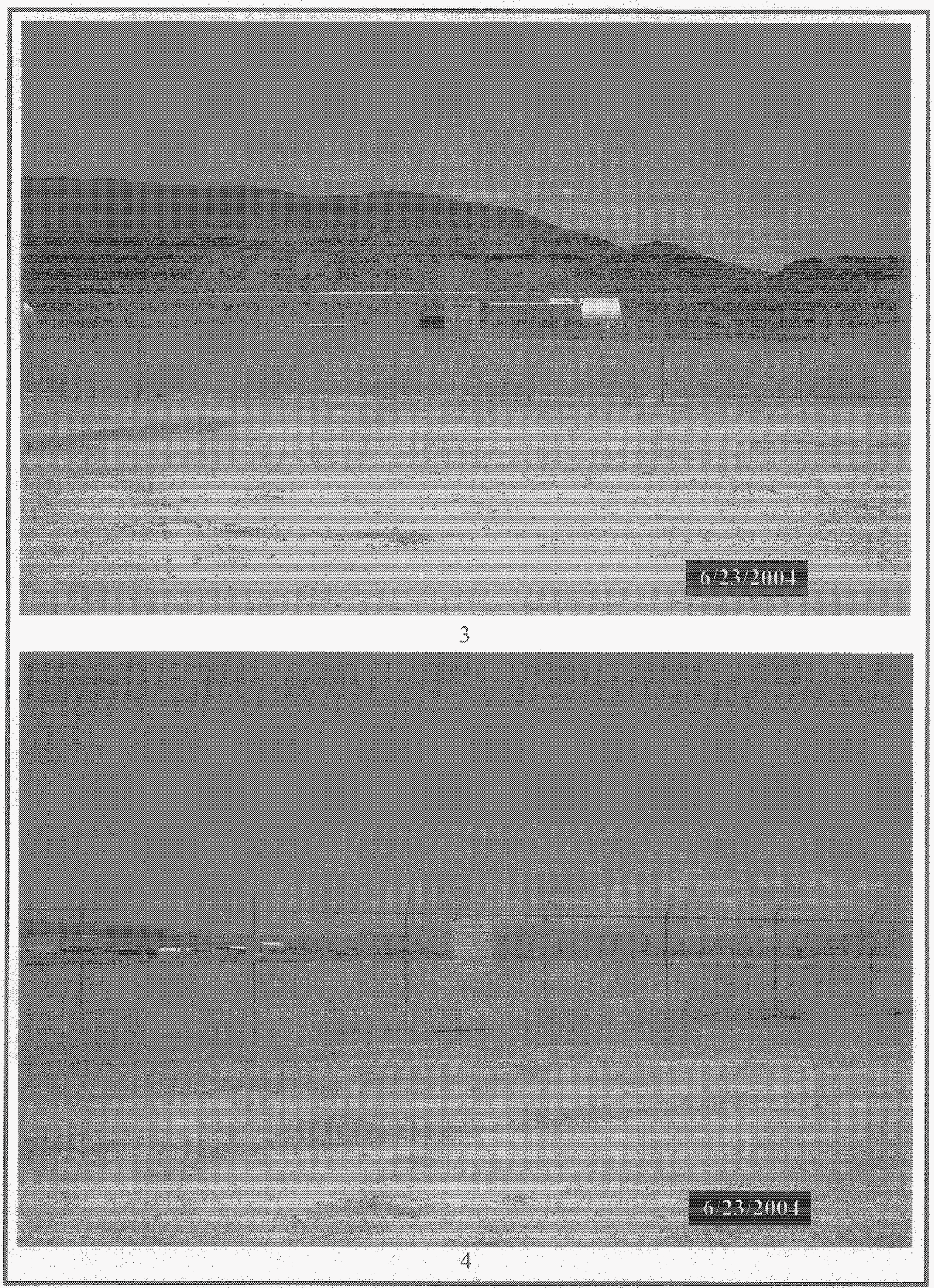


Post-Chowure Report - $\mathrm{CAU} 92$

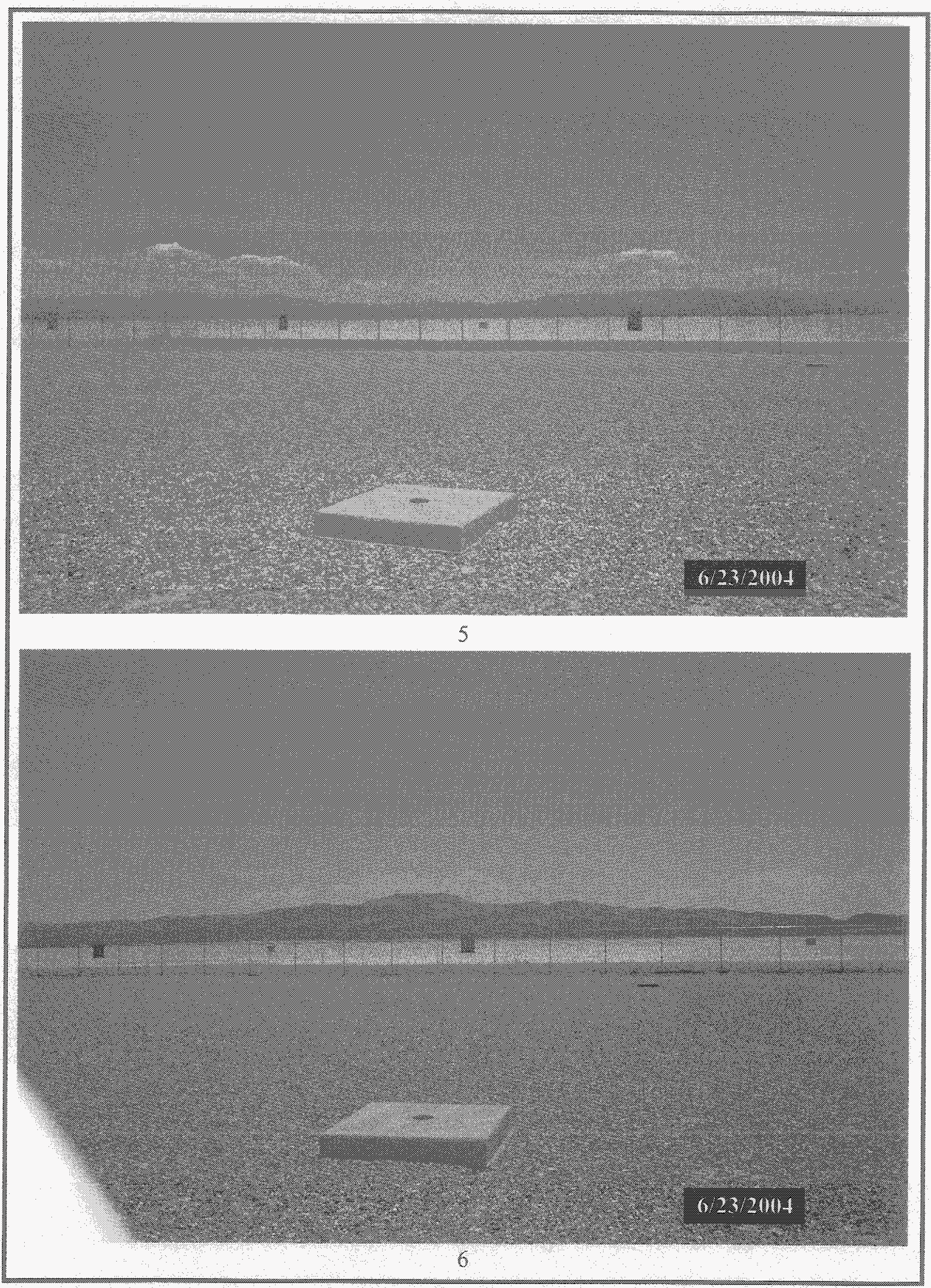




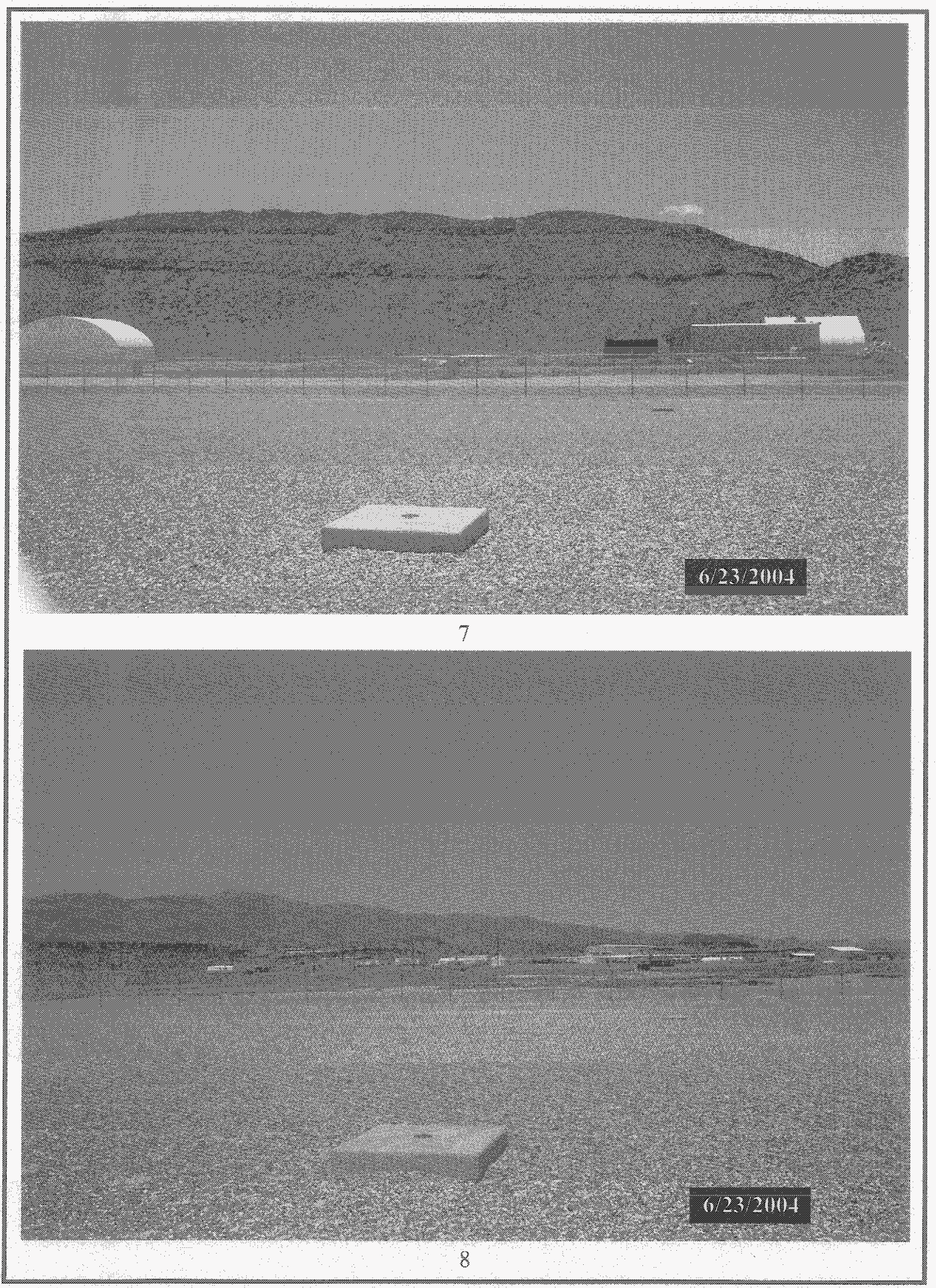



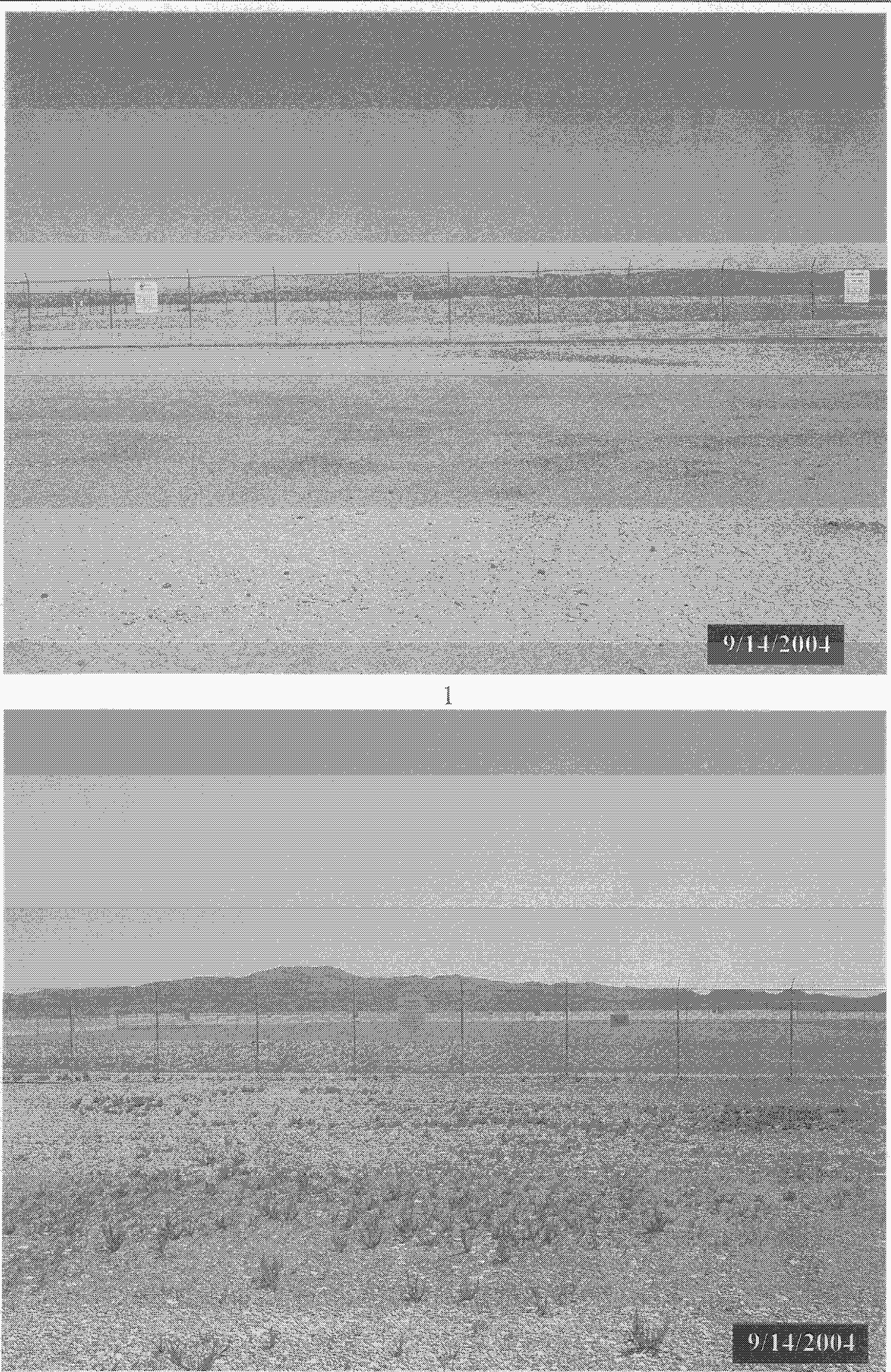
Pogt-Closure Ropor - CAU 92

Revision: 13

Date: Matren 2005
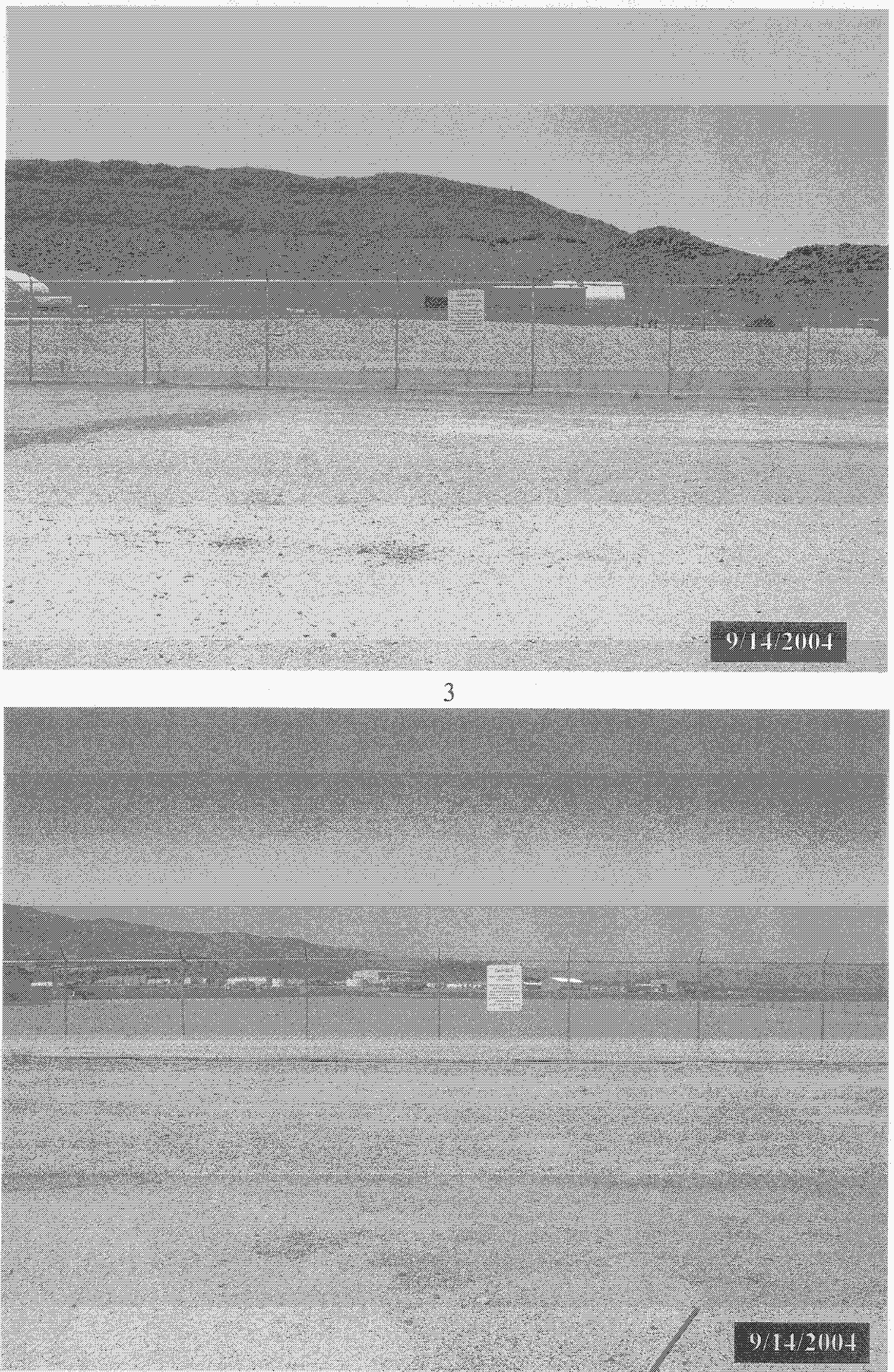


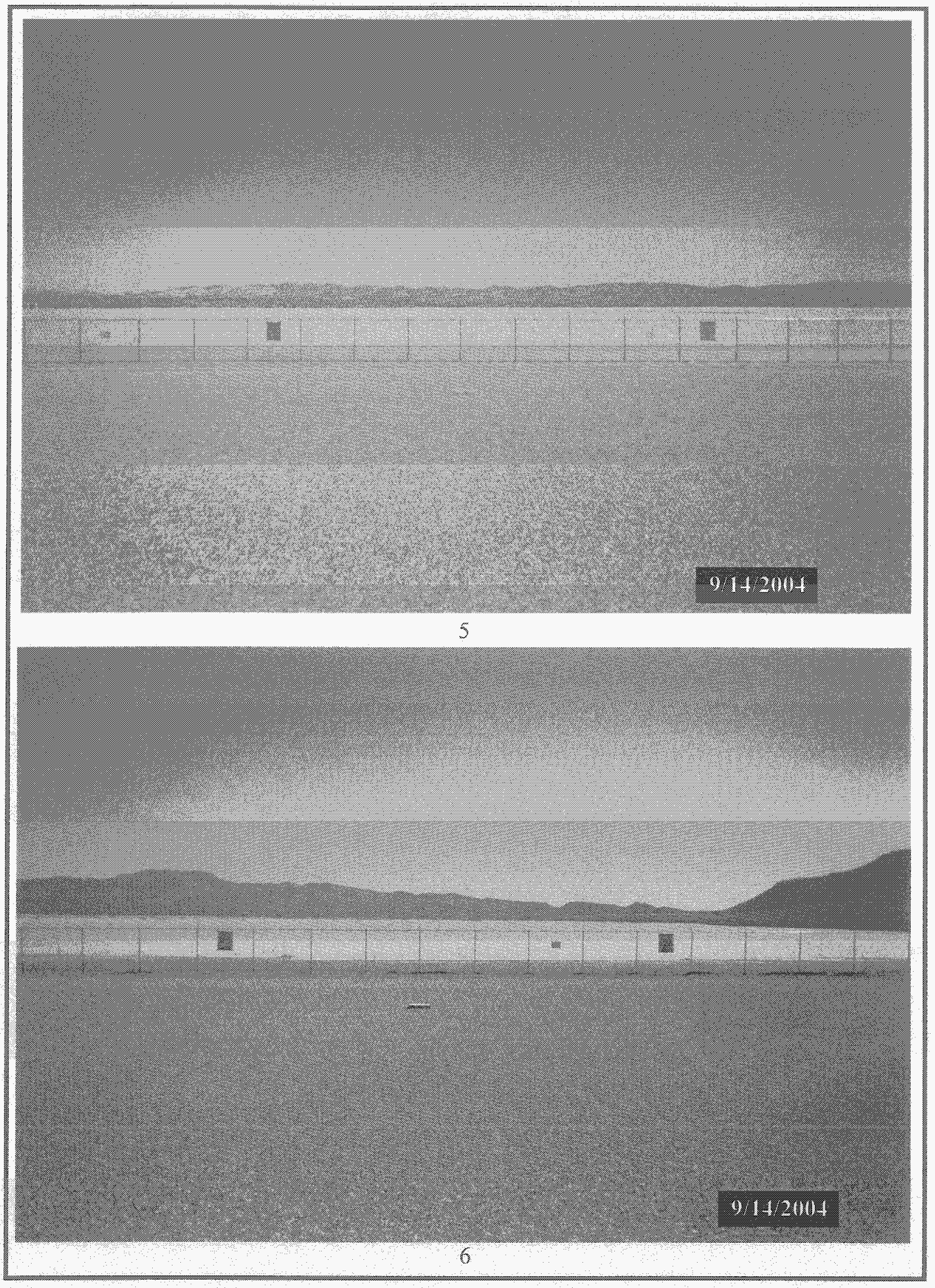


Post-Chowe Rown - CA J az

Revision:

Date: Maroh 2005
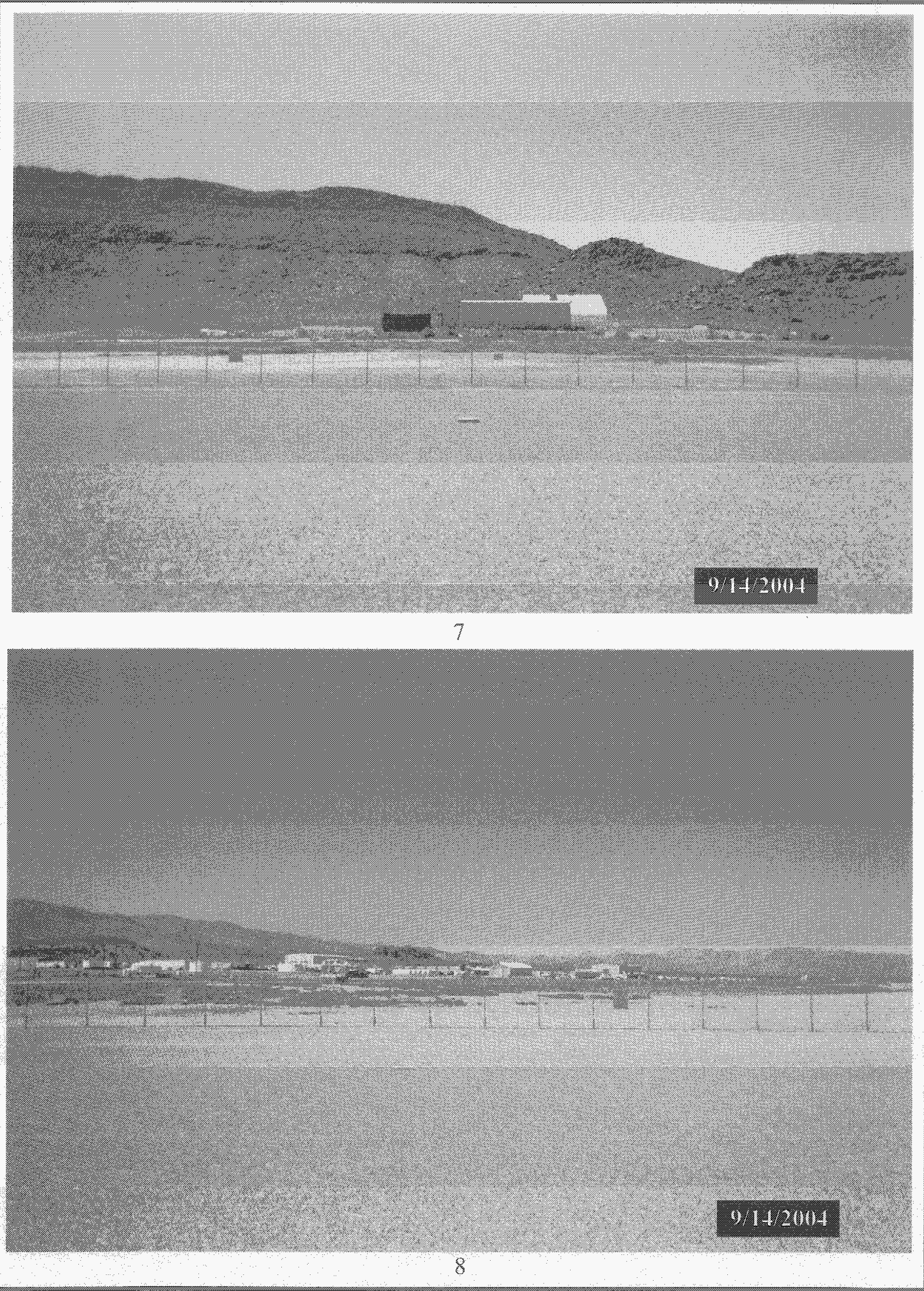


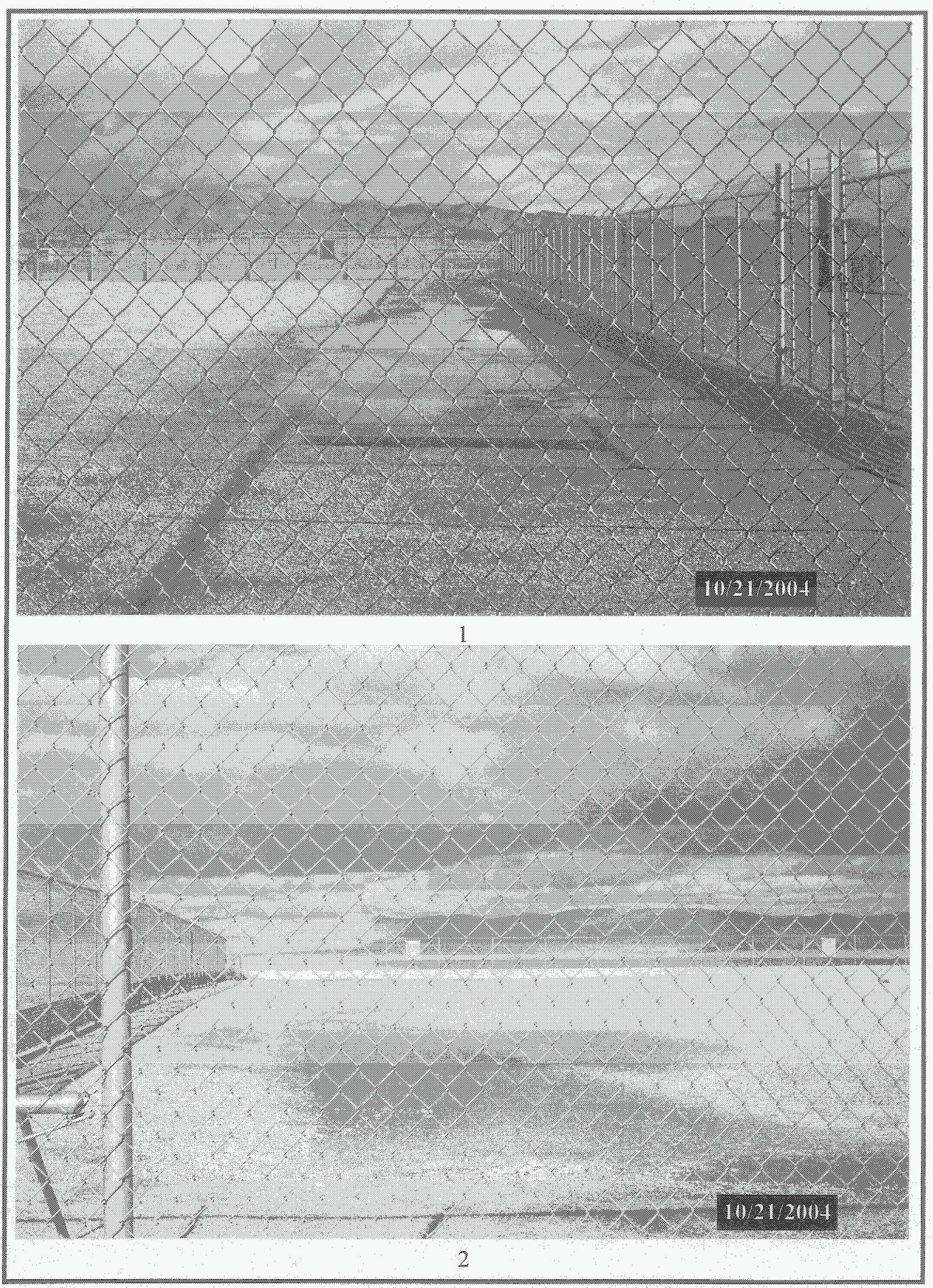


Pobt-Cosure Repor - CAU 92

Revision:

Date: March 200 s

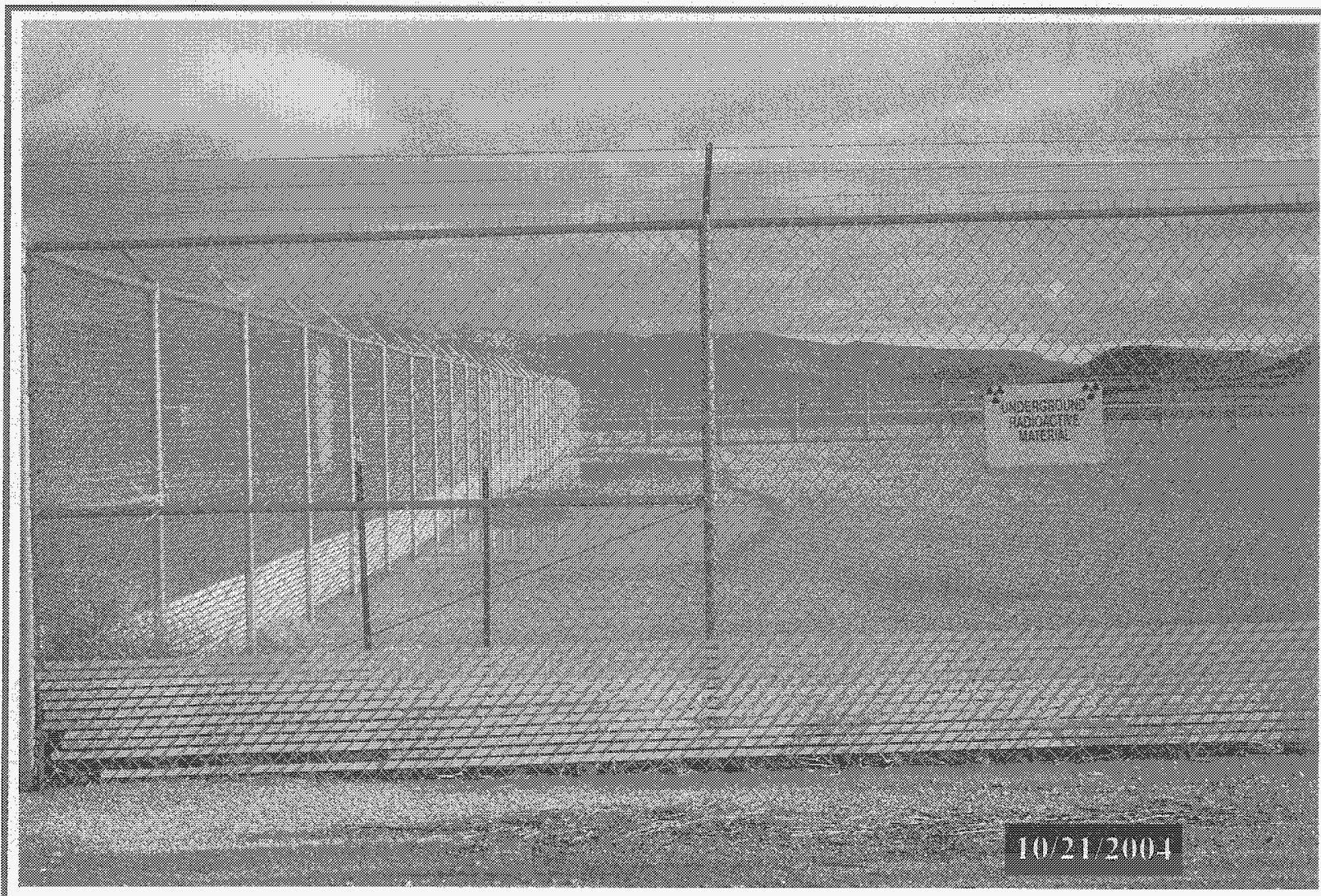




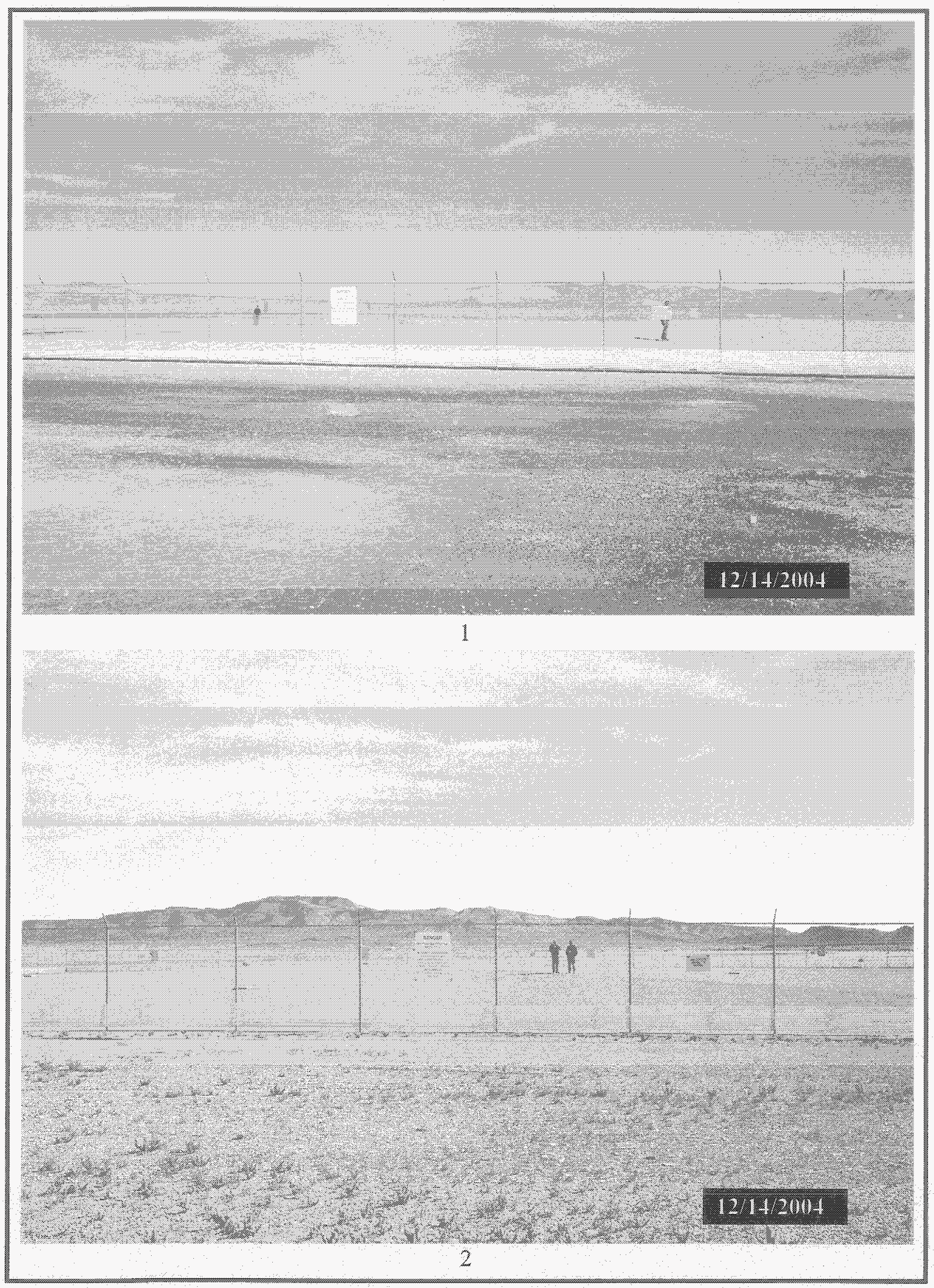


Post-Closure leport-CAU 92

Revision: 0

Date: Maren 2005

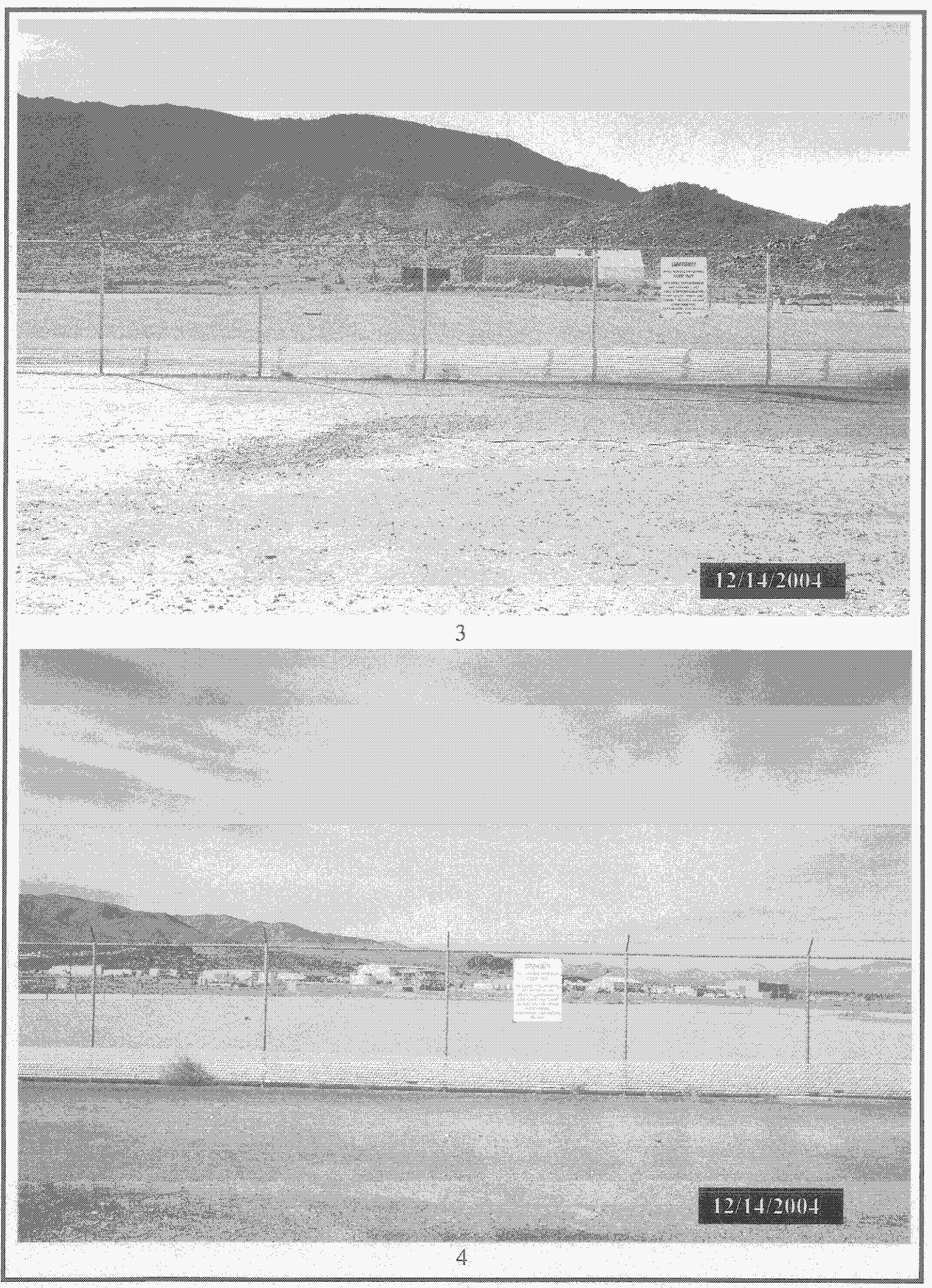




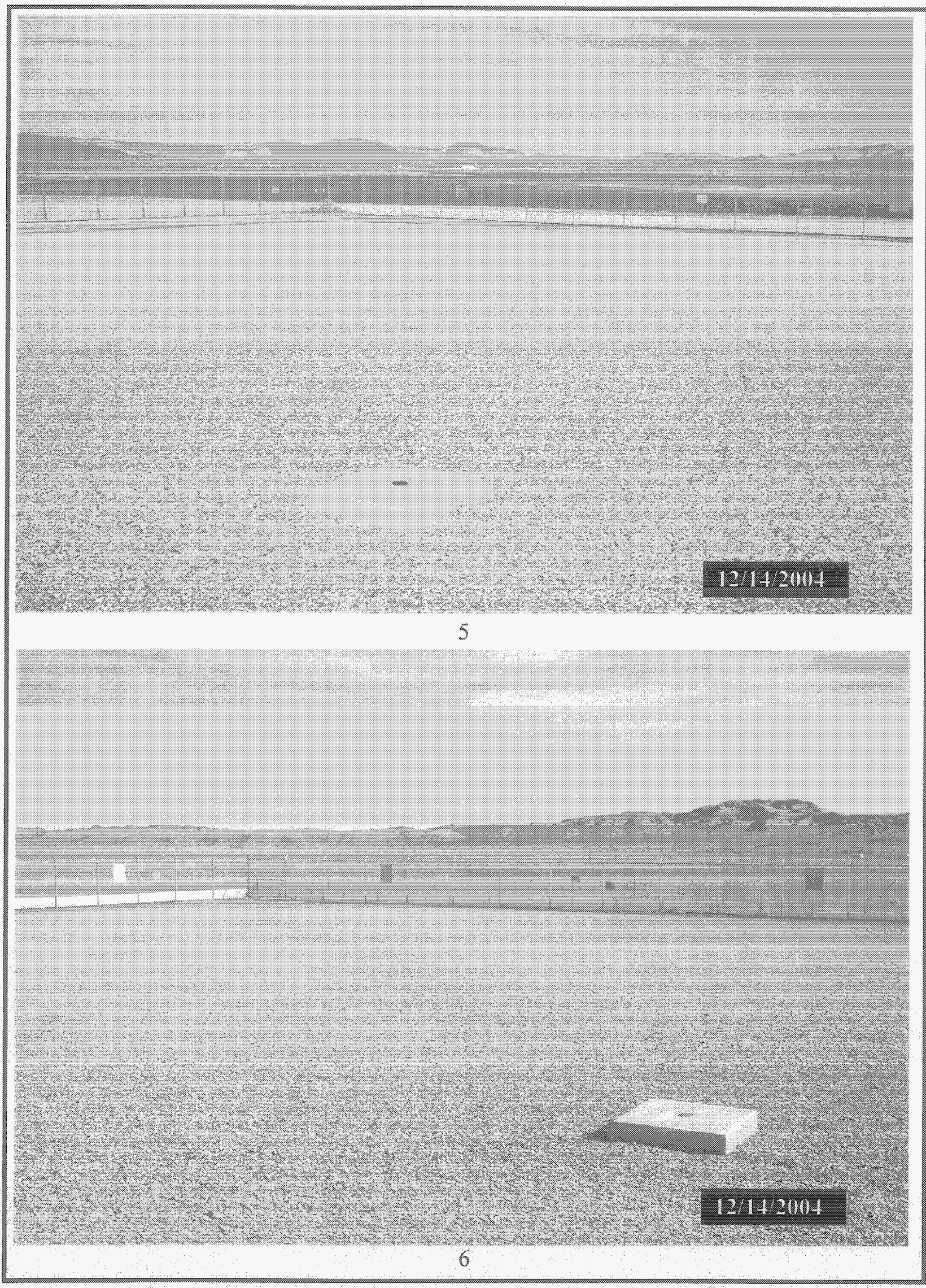




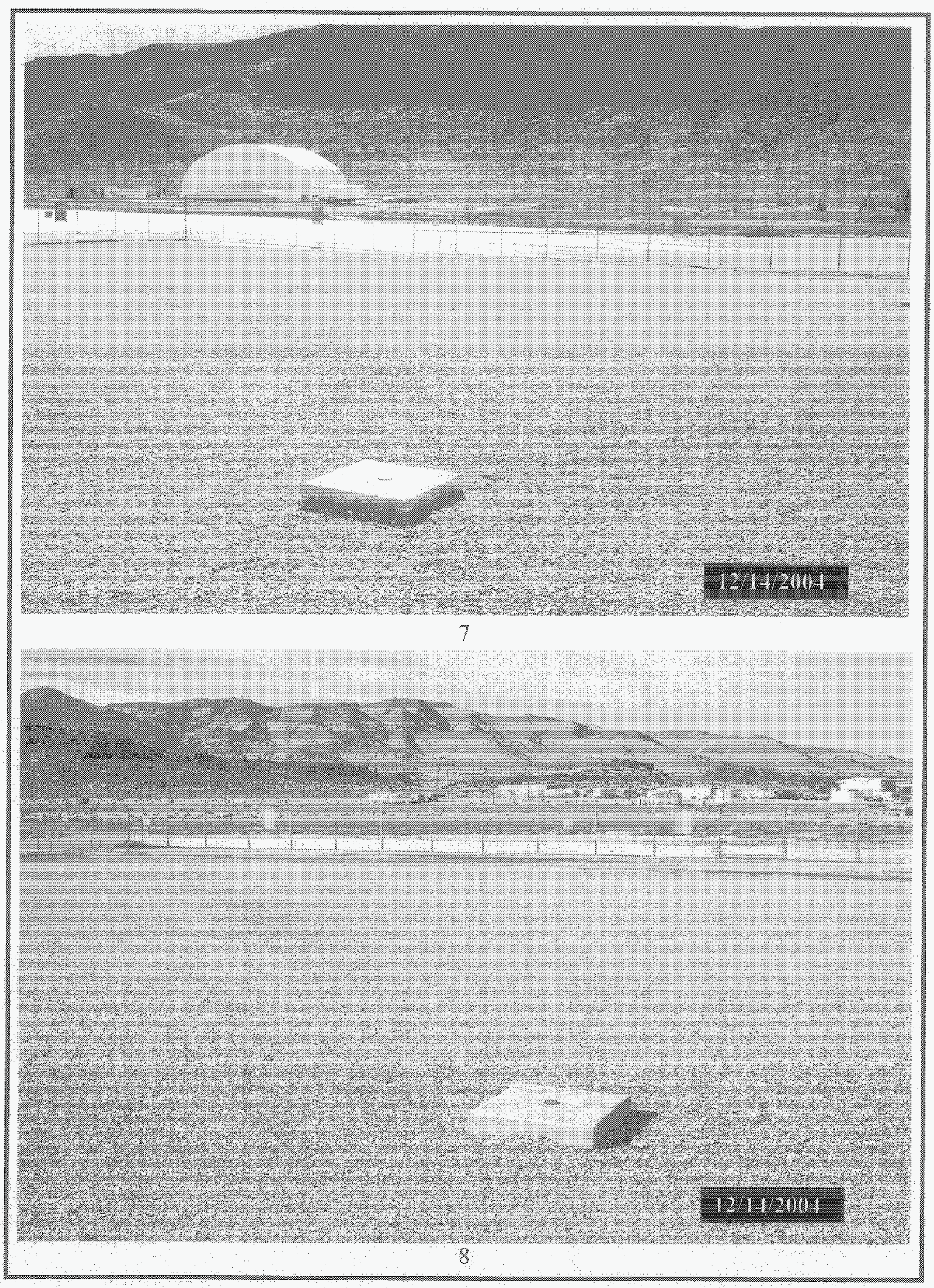




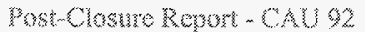

Revision:

Date March 2005

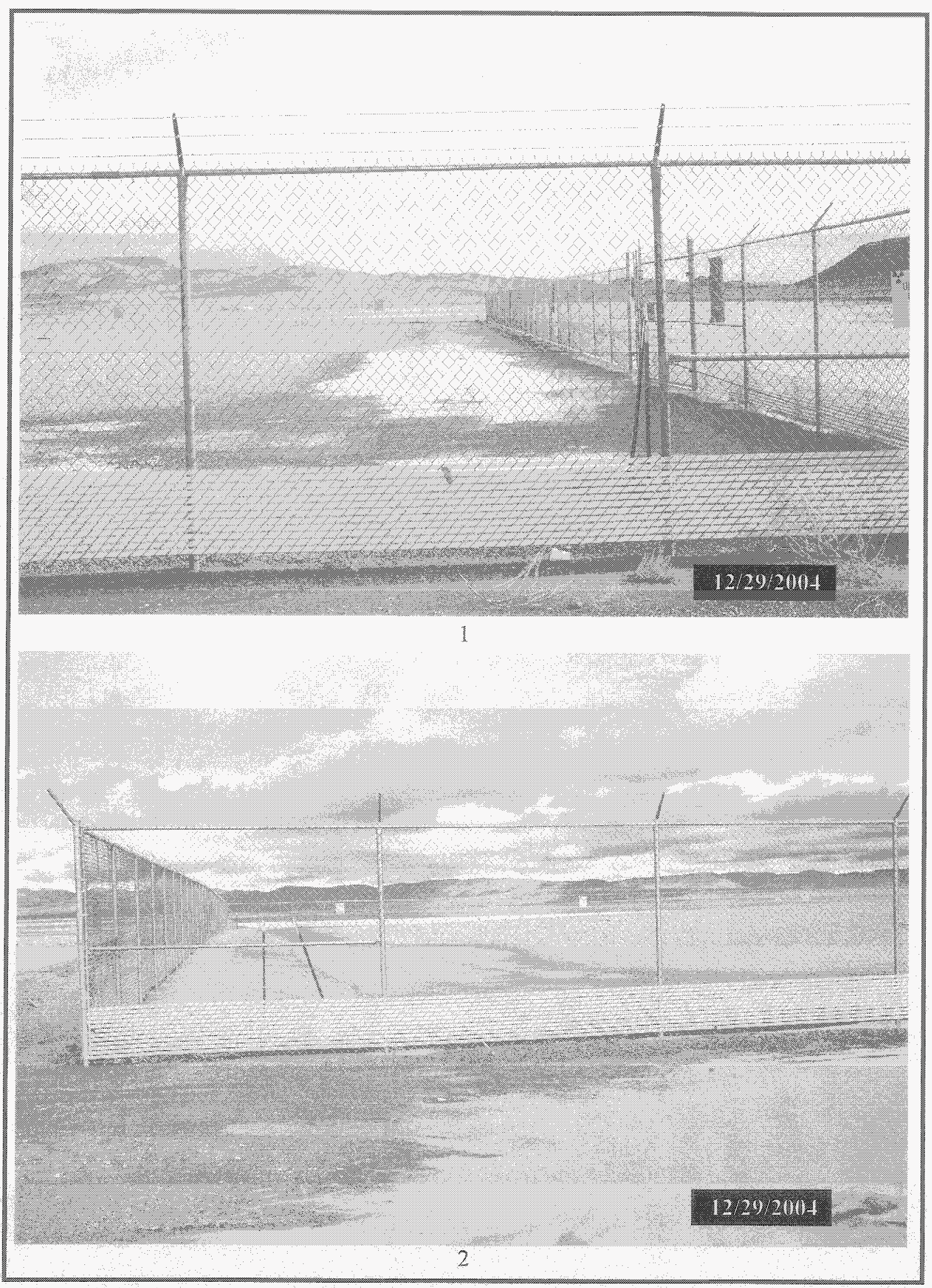


PostClosure Rapor - CAU is

Revision: 0

Wace: March 200

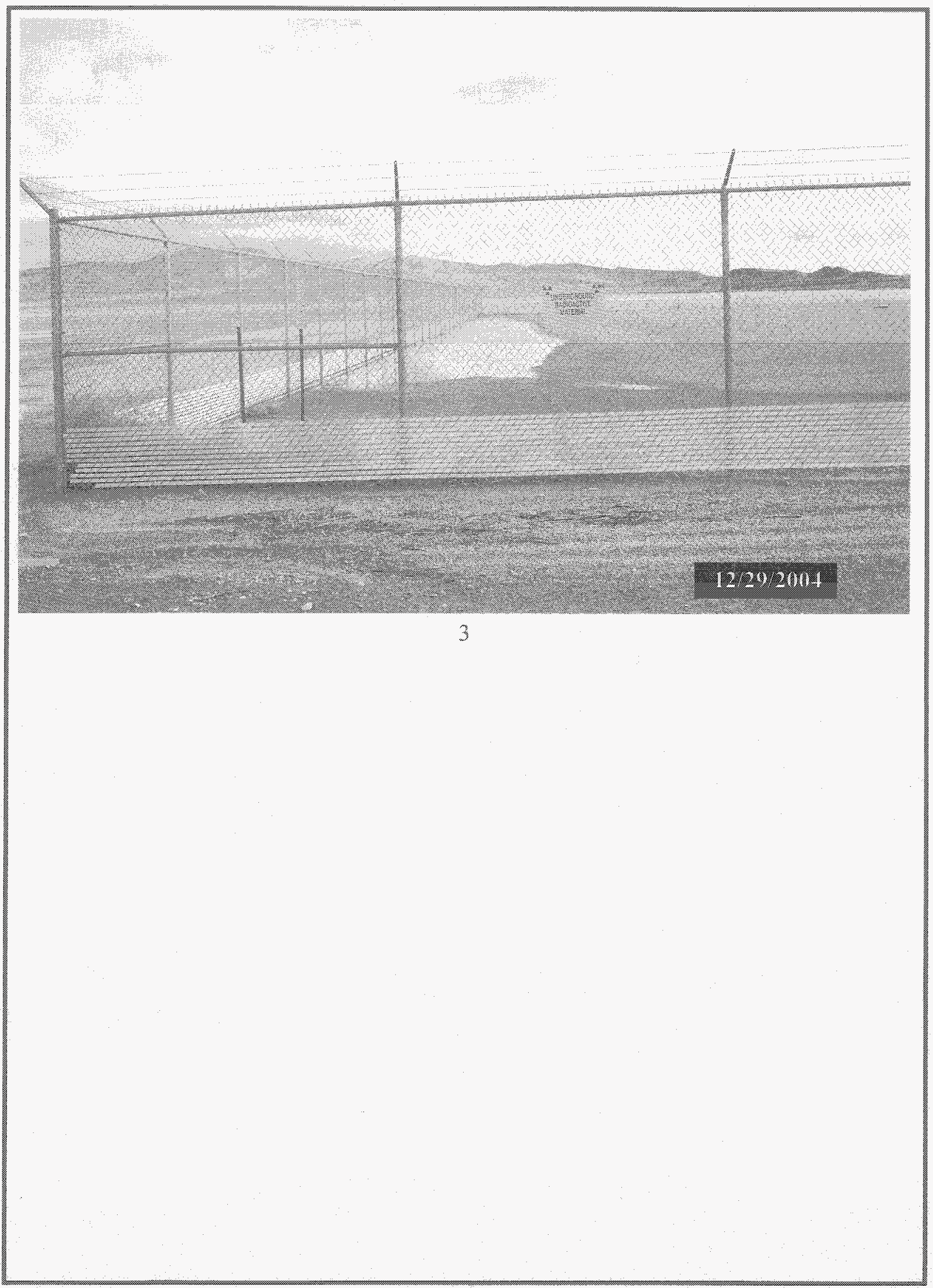


Post-Closure Report - CAU 92

Revision: 0

Date: March 2005

\section{APPENDIX C}

\section{PRECIPITATION RECORDS}


Post-Closure Report - CAU 92

Revision: 0

Date: March 2005

THIS PAGE INTENTIONALLY LEFT BLANK 


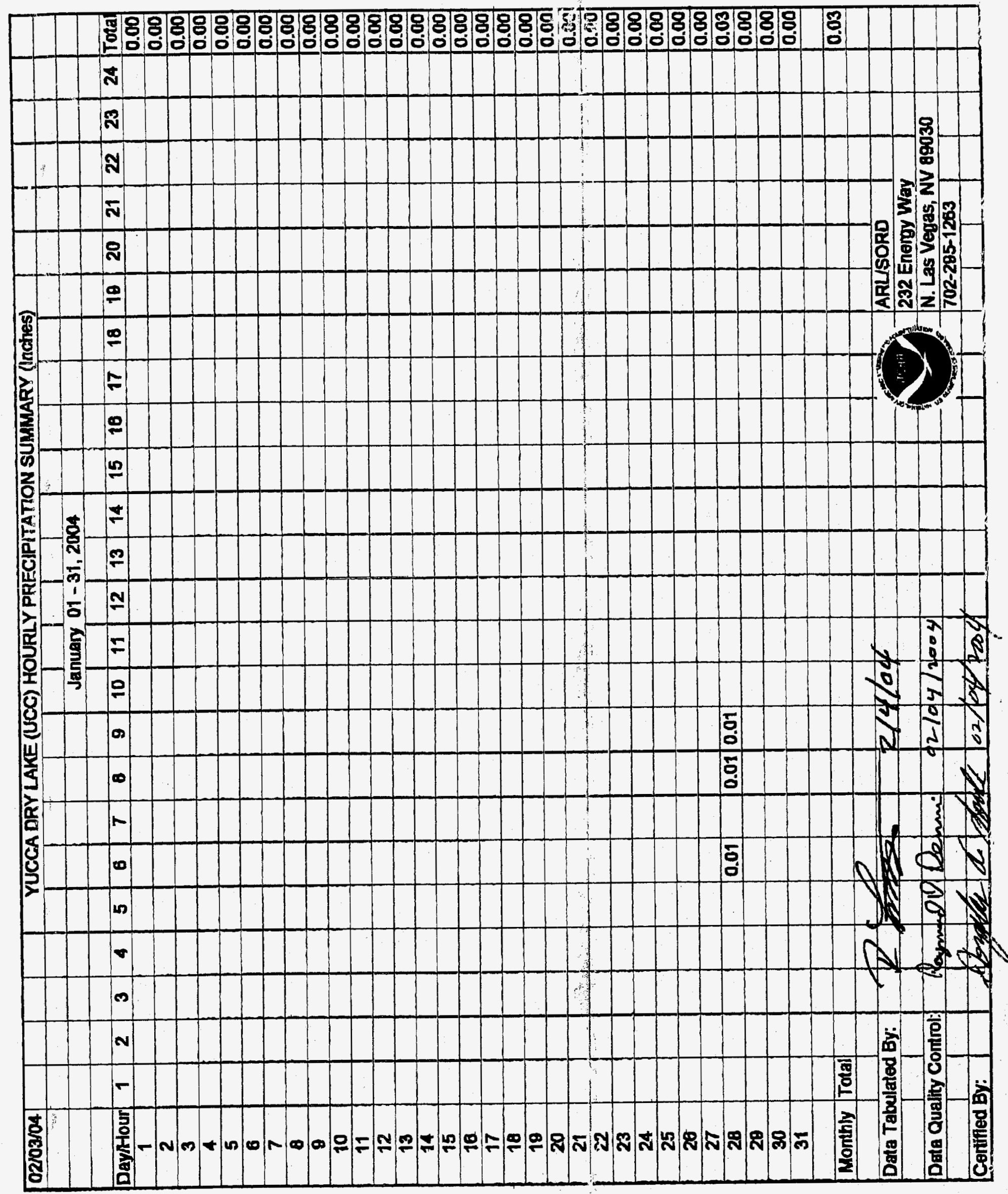




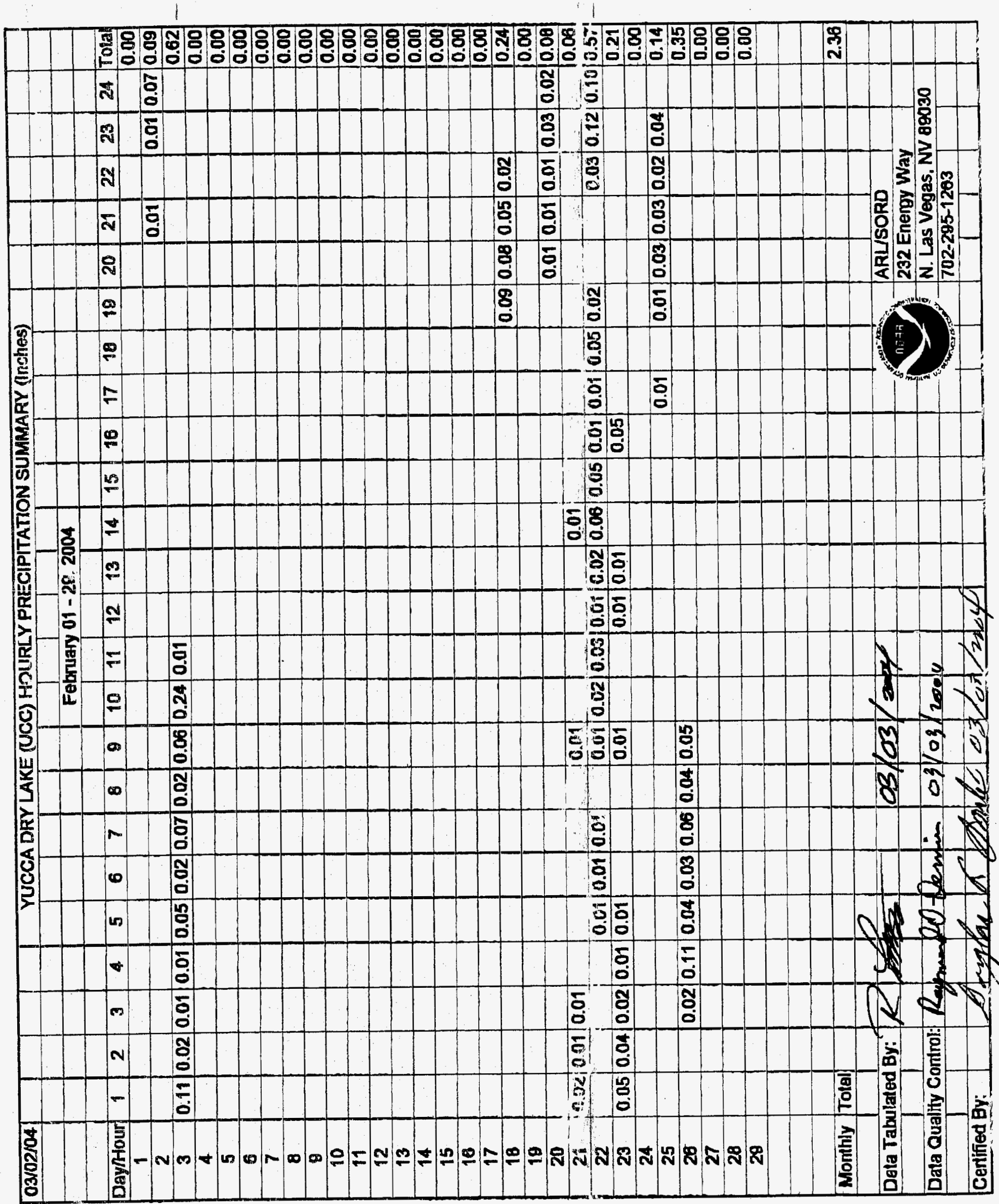

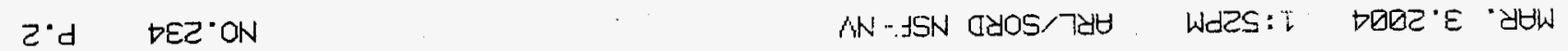




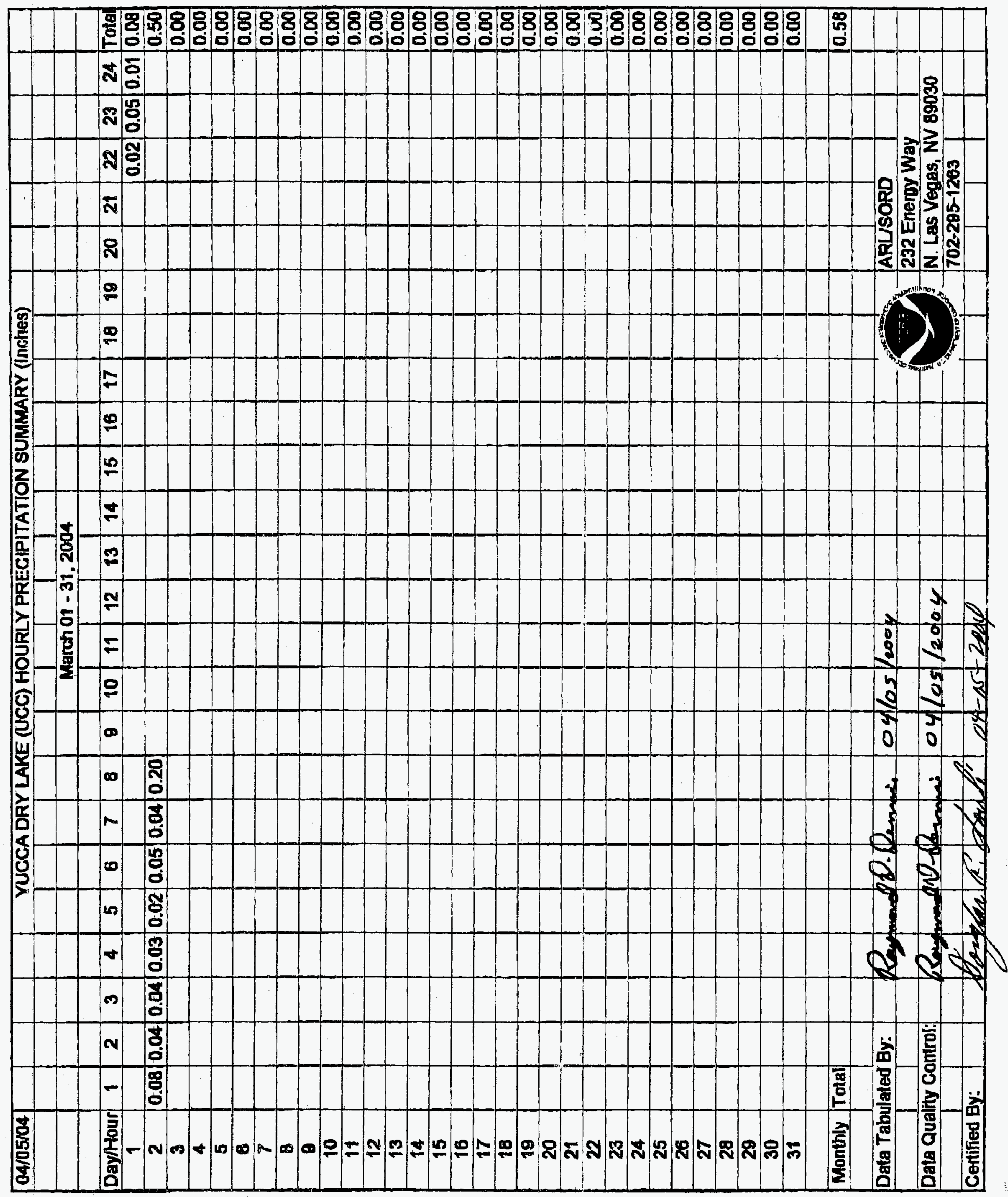




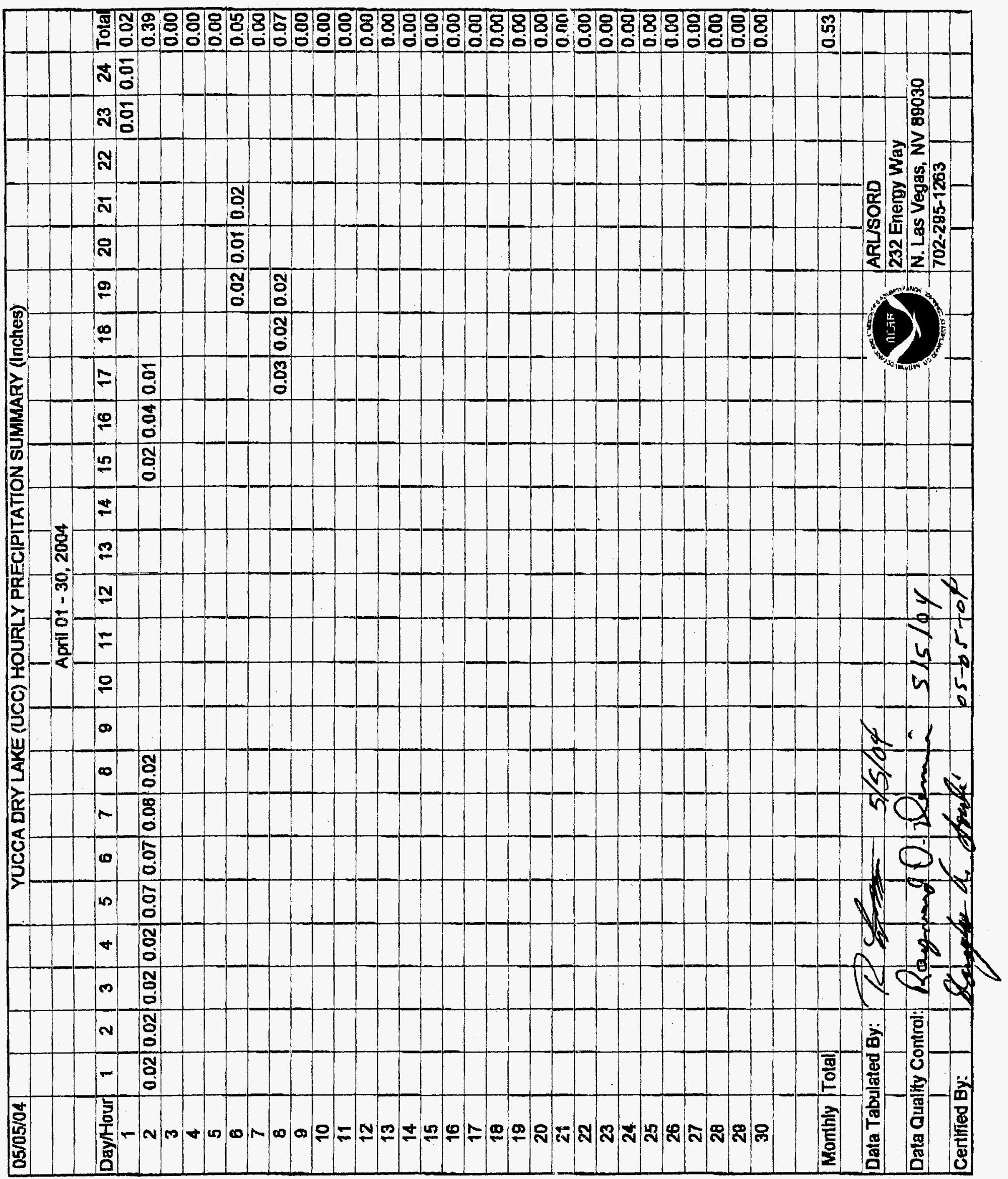




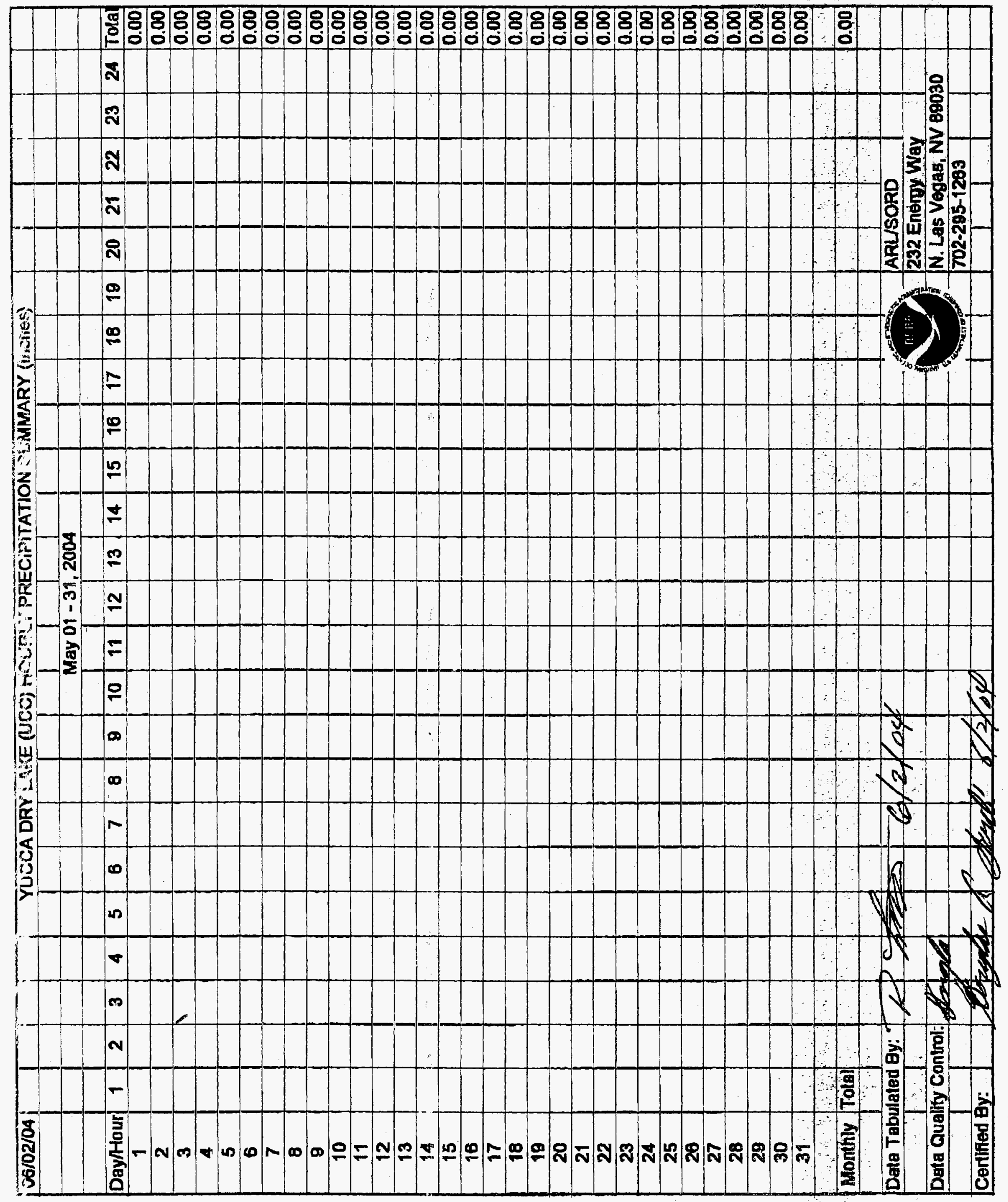




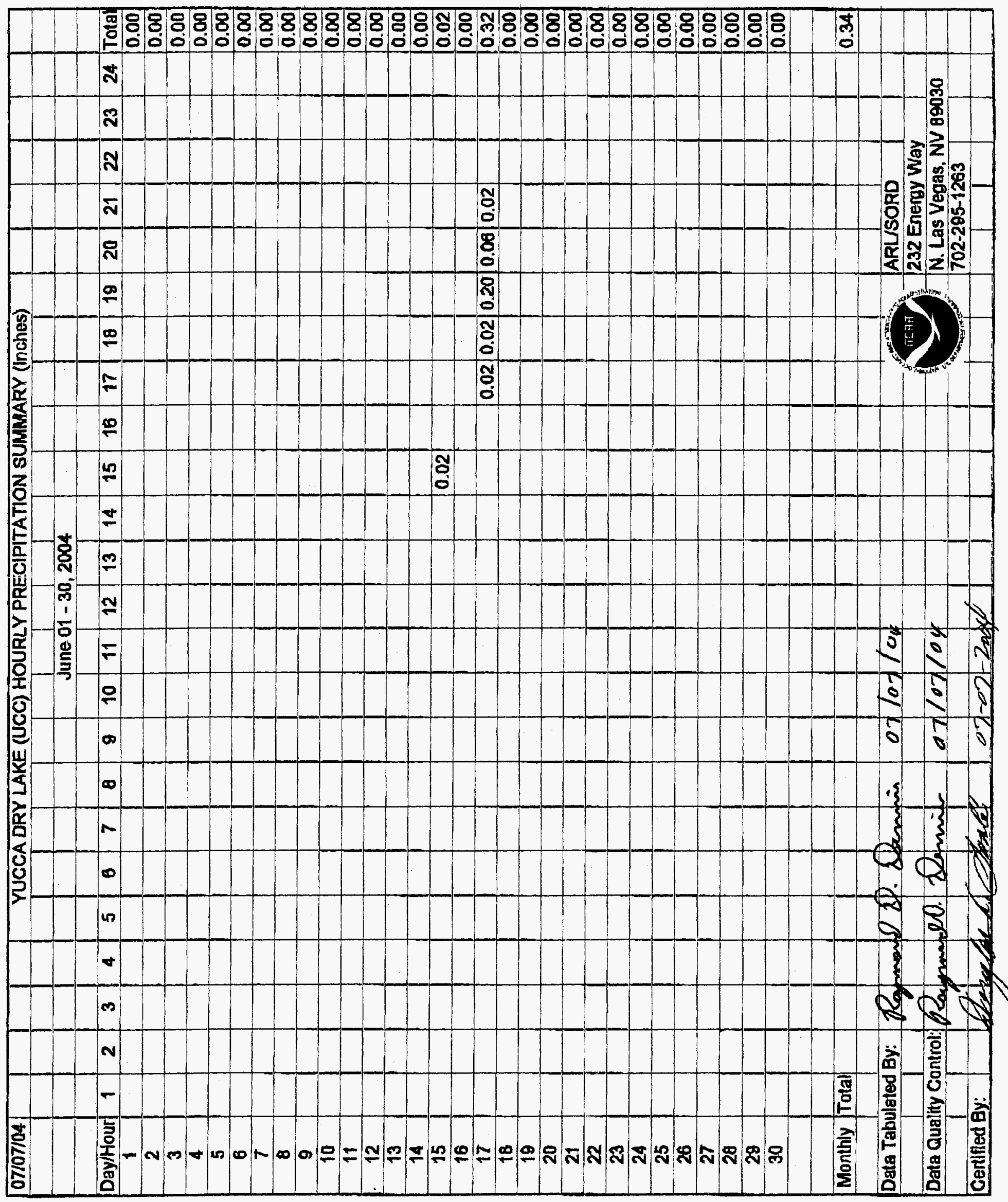




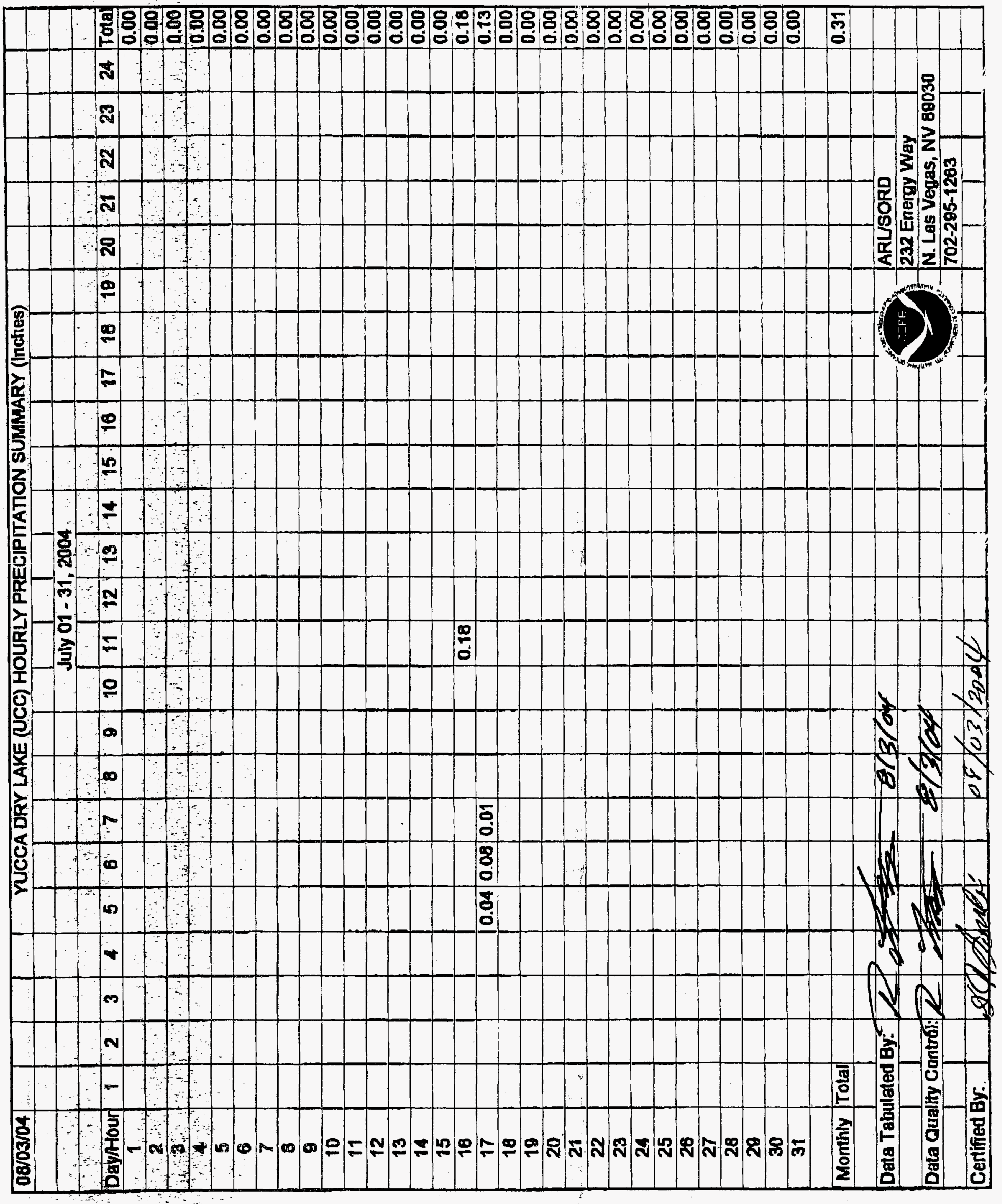




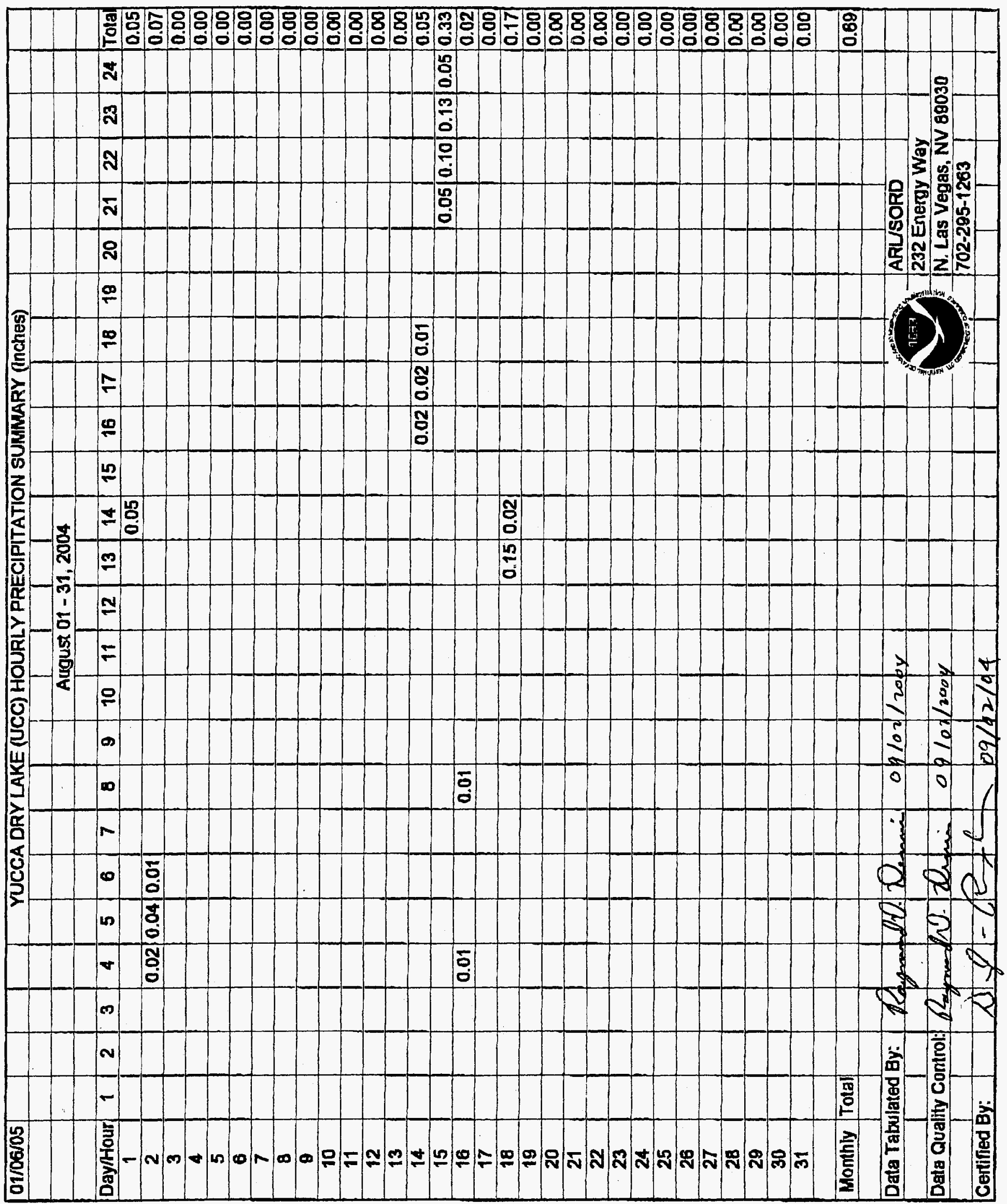




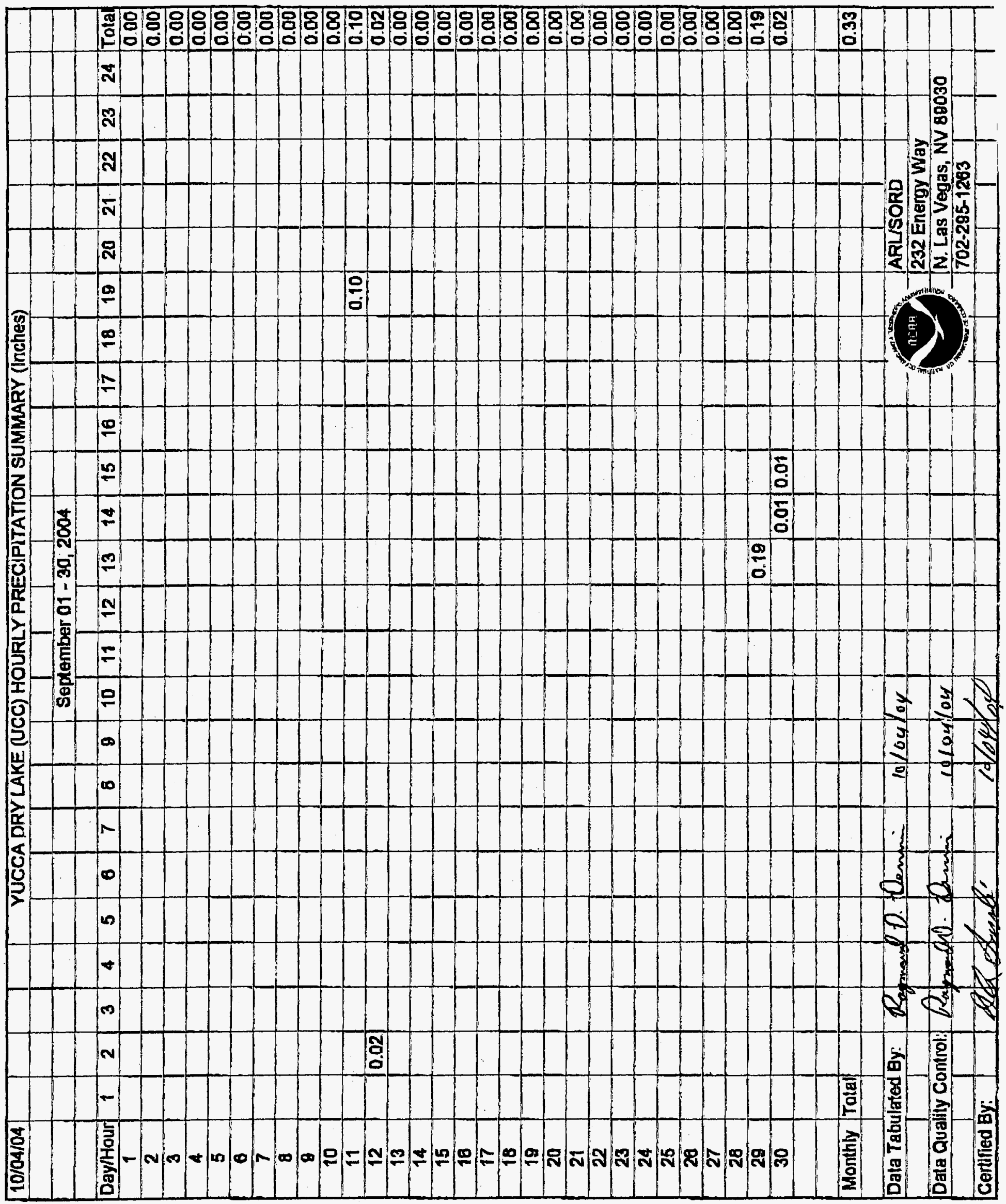




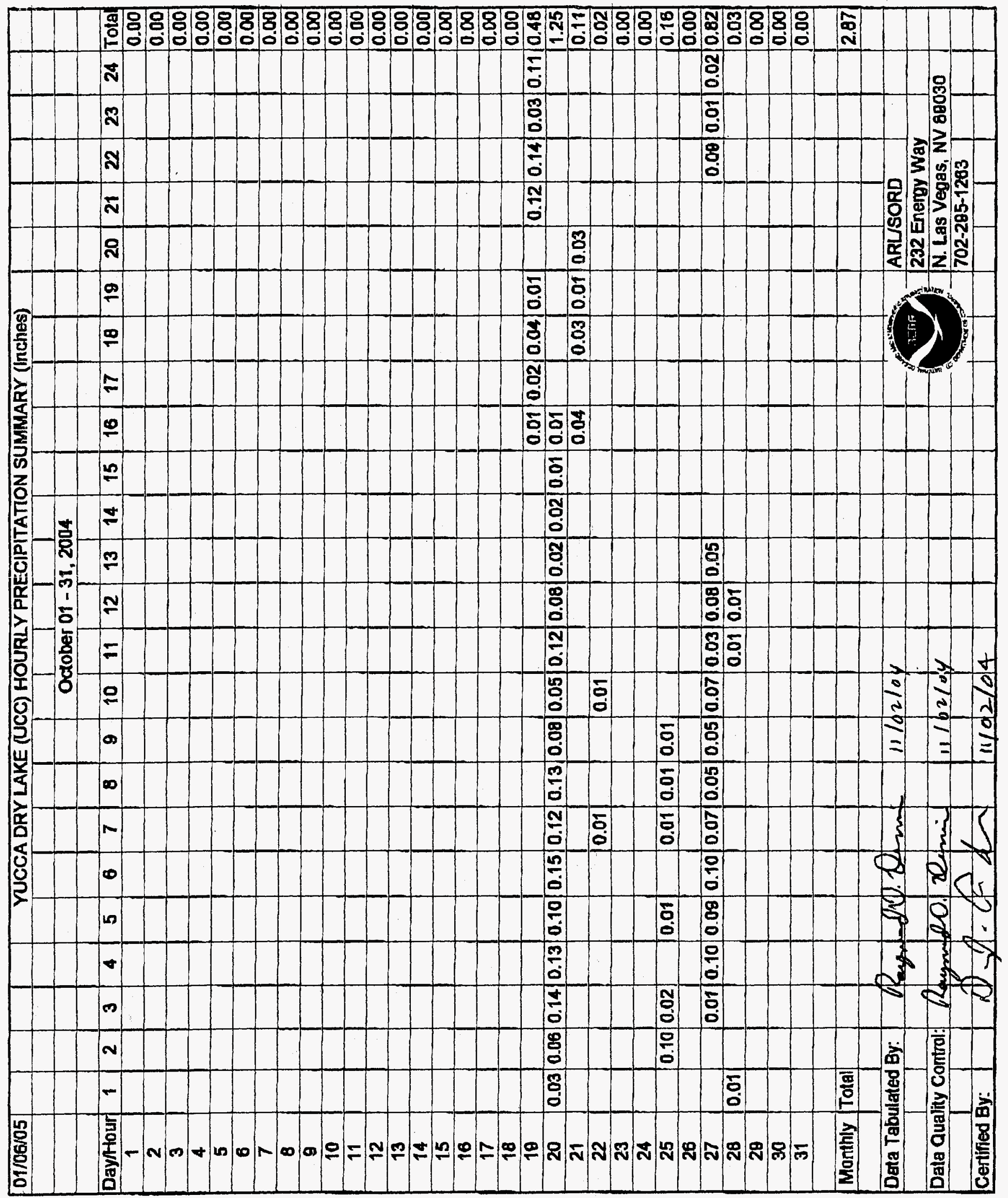




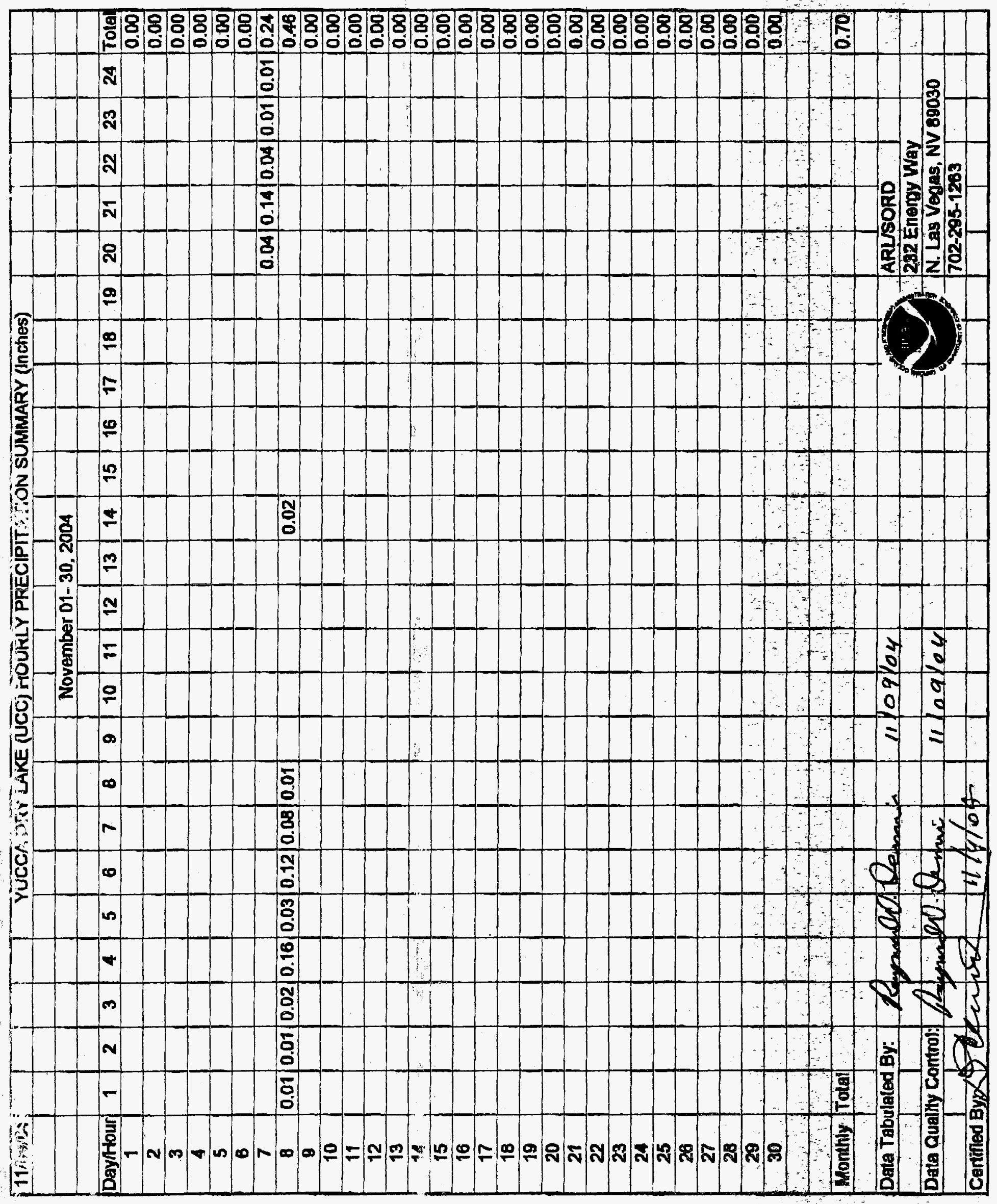




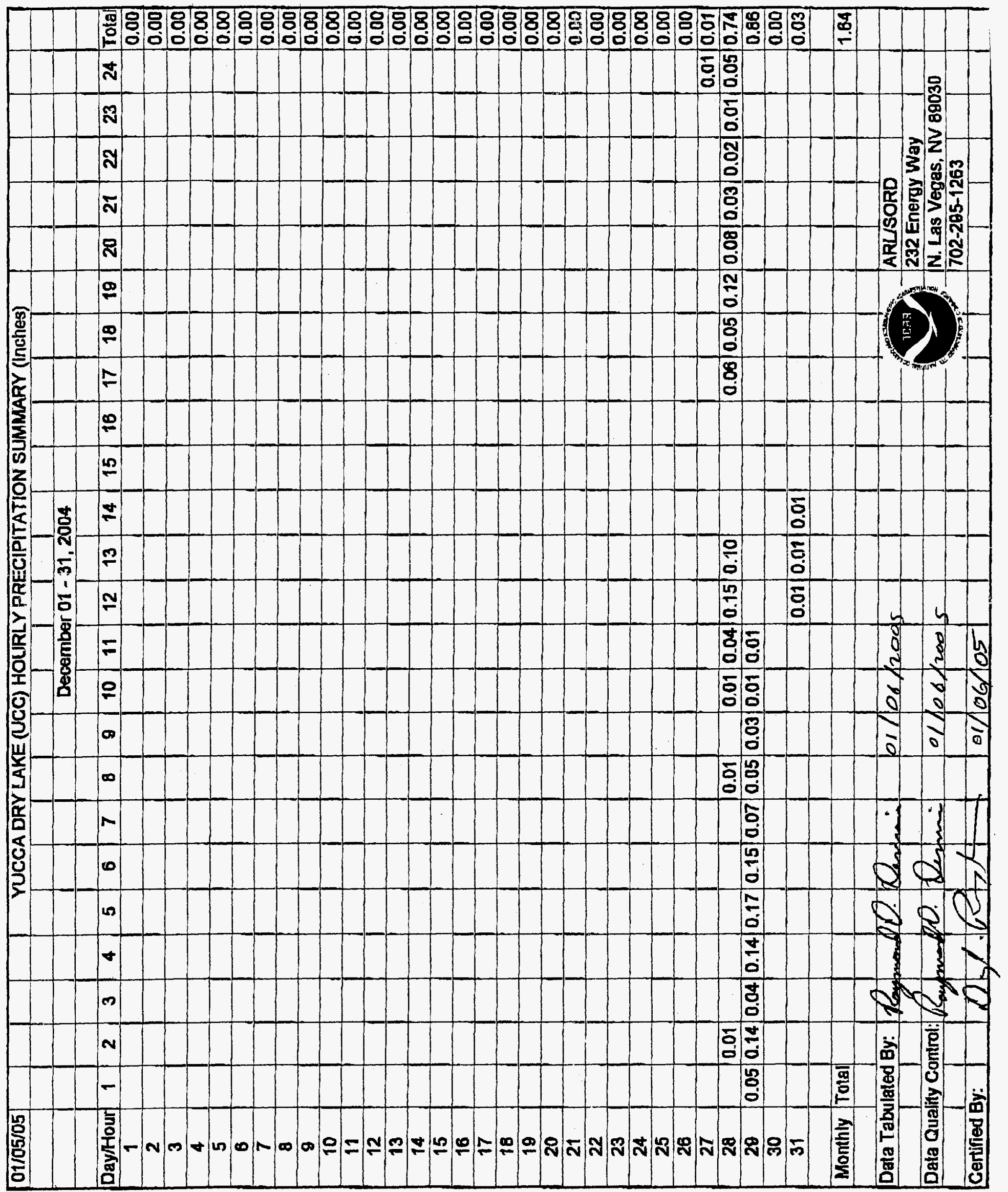


Post-Closure Report - CAU 92

Revision: 0

Date: March 2005

\section{LIBRARY DISTRIBUTION LIST}


Post-Closure Report - CAU 92

Revision: 0

Date: March 2005

THIS PAGE INTENTIONALLY LEFT BLANK 


\section{LIBRARY DISTRIBUTION LIST}

U.S. Department of Energy

National Nuclear Security Administration

Nevada Site Office

Technical Library

P.O. Box $98518, \mathrm{M} / \mathrm{S} 505$

Las Vegas, NV 89193-8518

U.S. Department of Energy

Office of Scientific and Technical Information

P.O. Box 62

Oak Ridge, TN 37831-0062

Southern Nevada Public Reading Facility

c/o Nuclear Testing Archive

P.O. Box 98521, M/S 400

Las Vegas, NV 89193-8521

Manager, Northern Nevada FFACO

Public Reading Facility

c/o Nevada State Library \& Archives

Carson City, NV 89701-4285
1 (Uncontrolled)

1 (Uncontrolled, electronic copy)

2 (Uncontrolled, electronic copies)

1 (Uncontrolled, electronic copy) 
Post-Closure Report - CAU 92

Revision: 0

Date: March 2005

THIS PAGE INTENTIONALLY LEFT BLANK 